\title{
DINOPHYSIALES (DINOPHYCEAE) OF THE NATIONAL PARK SISTEMA ARRECIFAL VERACRUZANO, GULF OF MEXICO, WITH A KEY FOR IDENTIFICATION
}

\author{
YURI B. OKOLODKOV \\ Universidad Veracruzana, Instituto de Ciencias Marinas y Pesquerías, \\ Laboratorio de Botánica Marina y Planctología, Calle Hidalgo 617, \\ Colonia Río Jamapa, 94290 Boca del Río, Veracruz, Mexico. \\ yuriokolodkov@yahoo.com
}

\begin{abstract}
The morphology of 38 species from eight genera of the order Dinophysiales was studied based on about seven hundred $20 \mu \mathrm{m}$ phytoplankton net samples taken from May 2005 through April 2008 at 27 sampling stations in the National Park Sistema Arrecifal Veracruzano, southwestern Gulf of Mexico. Short descriptions and synonyms are given for each species. Cell size variation with the mean and the standard deviation are given for most species. Twentythree species are provided with affinities and morphological, taxonomic and nomenclatural comments. Dichotomous keys for identification of the genera and species of Amphisolenia (4 species), Dinophysis (7), Heteroschisma (1), Histioneis (6), Ornithocercus (7), Phalacroma (9), Pseudophalacroma (1) and Sinophysis (3) are presented, and species are illustrated with light and scanning electron microscope photographs and line drawings. Phalacroma equalanti (Balech) Okolodkov comb. nov. is established. Thirteen species are new records for the State of Veracruz, and Histioneis isseli and Pseudophalacroma nasutum are new for the Gulf of Mexico.
\end{abstract}

Key words: dinoflagellates, Dinophysiales, Gulf of Mexico, key for identification, morphology, taxonomy.

\section{RESUMEN}

Se estudió la morfología de 38 especies de ocho géneros del orden Dinophysiales con base en aproximadamente 700 muestras de red fitoplanctónica $(20 \mu \mathrm{m})$ tomadas de mayo de 2005 a abril de 2008 en 27 estaciones de muestreo en el Parque Nacional Sistema Arrecifal Veracruzano, 
la parte suroeste del Golfo de México. Para cada especie se dan descripciones cortas, así como la sinonimia. La variación del tamaño de las células, el promedio y la desviación estándar se presentan para la mayoría de especies. Para 23 se proporcionan notas sobre sus afinidades, al igual que comentarios morfológicos, taxonómicos y nomenclaturales. Se presentan claves dicotómicas para la identificación de los géneros y especies de Amphisolenia (4 especies), Dinophysis (7), Heteroschisma (1), Histioneis (6), Ornithocercus (7), Phalacroma (9), Pseudophalacroma (1) y Sinophysis (3), así como las fotografías en microscopio fotónico y microscopio electrónico de barrido e ilustraciones de todas las entidades encontradas. Se establece Phalacroma equalanti (Balech) Okolodkov comb. nov. Trece especies son nuevos registros para el Estado de Veracruz, e Histioneis isseli y Pseudophalacroma nasutum lo son para el Golfo de México.

Palabras clave: clave para identificación, dinoflagelados, Dinophysiales, Golfo de México, morfología, taxonomía.

\section{INTRODUCTION}

The order Dinophysiales with about 280 species (Gómez et al., 2011a) is monophyletic (Saldarriaga et al., 2004) and morphologically well distinguished by a sagittal suture encircling the entire cell. The order is represented by only three families, Dinophysiaceae F. Stein, Amphisoleniaceae Lindemann and Oxyphysiaceae Sournia, which comprise 13-14, 2 and 1 recent genera, respectively (Fensome et al., 1993). Most genera and species are marine planktonic; however, a typically benthic/ epiphytic Sinophysis Nie et Wang is also known from the sea. Some genera such as Citharistes F. Stein and Histioneis F. Stein, and possibly Ornithocercus F. Stein, Amphisolenia F. Stein and Triposolenia Kof., prefer oceanic waters (Okolodkov, 2011). The highest generic and species diversities are found in tropical seas. Dinophysis Ehrenberg sensu lato is the most common genus, distributed throughout all the oceans including both polar regions, with the largest number of species. Recently described small cells in about a dozen Dinophysis species, responsible for infraspecific morphological variability (dimorphism), are believed to be gametes in a three-looped life-history pattern, which consists of sexual, small/intermediate cell and vegetative cell cycles (Hansen, 1993; Reguera et al., 1995, 2007, 2012; Reguera \& González-Gil, 2001; Reguera, 2002). Pellicle cysts, more frequently and misleadingly called temporary cysts in the literature, are not known for any of the Dinophysiales genera (Bravo et al., 2009). Resting (hypnozygotic) cysts are reliably known for Dinophysis acuta Ehrenb. and D. tripos Gourret (Cannon, 1993; Moita \& Sampayo, 1993; Head, 1996). 
Most Dinophysiales are heterotrophic and are known to feed by myzocytosis with a peduncle (Elbrächter, 1991). Plastids of photosynthetic species have predominantly a cryptophyte origin (Lucas \& Vesk, 1990). The genera Ornithocercus, Citharistes, Histioneis, Amphisolenia and Triposolenia may have cyanobacteria symbionts, extracellular (the former three genera) or intracellular (the latter two), belonging to the genera Synechococcus Nägeli and Synechocystis Sauvageau, sometimes called phaeosomes (Norris, 1967; Taylor, 1982; Hallegraeff \& Jeffrey, 1984; Lucas, 1991; Fensome et al., 1993; Gordon et al., 1994; Carpenter, 2002; Handy et al., 2009).

Twelve Dinophysis species are known to be causative agents of diarrheic shellfish poisoning due to accumulation of toxins (okadaic acid, dinophysistoxin-1 and -2, and pectenotoxin-2). In 2008, a bloom caused by Dinophysis species, primarily by D. ovum (also reported as D. cf. ovum or the Dinophysis acuminata complex), was detected in Texas coastal waters, the western Gulf of Mexico, along with the presence of okadaic acid (Campbell et al., 2010; Swanson et al., 2010; Fux et al., 2011). This was the first record of toxicity caused by Dinophysis species in North American shellfish; it had been previously recorded in some areas in Europe and Asia (Hess \& Nicolau, 2010). Recent advances in the understanding of the physiology (including toxicity), ecology and evolution of the Dinophysiales species are and will be related to the success in culturing Dinophysis species in a three-stage system involving (1) cultivation of cryptophytes, (2) feeding them to ciliate prey Myrionecta rubra (Lohmann) Jankowski, and (3) feeding of the latter to the Dinophysis cells (Park et al., 2006; Nishitani et al., 2008; Tong et al., 2010).

Molecular studies (rRNA gene sequences) of the species of the family Dinophysiaceae showed separation between the genera Dinophysis sensu stricto and Phalacroma F. Stein and a closer affinity of the former to Ornithocercus and Histioneis than to Phalacroma (Handy et al., 2009; Jensen \& Daugbjerg, 2009; Gómez et al., 2011b). Chlorophyll-containing Dinophysis species form a separate clade, and the species hitherto ascribed to the genus Phalacroma belong to different clades (Gómez et al., 2011a). In addition, the only benthic dinophysioid genus, Sinophysis, and a planktonic genus, Pseudophalacroma Jörg. ex Lebour, were supposedly divergent with respect to the typical dinophysioid dinoflagellates (Dinophysiales sensu stricto), suggesting that dinophysioid dinoflagellates as a whole might not form a monophyletic group (Gómez et al., 2012). However, this requires more molecular evidence.

In the most recent checklist of dinoflagellates of the Gulf of Mexico, Steidinger et al. (2009) mentioned 136 species distributed between the families Dinophysiaceae (111, including two Citharistes species), Amphisoleniaceae (24) and Oxyphysiaceae (1). Unlike these authors, who considered the family Oxytoxaceae belonging to the 
Dinophysiales, I follow the classification of Fensome et al. (1993), who ascribe this family to the order Gonyaulacales. Similarly, Citharistaceae is not separated here as a family. Norris (1969) documented nine Histioneis and seven Ornithocercus species from the southeastern Gulf of Mexico with line drawings. Licea et al. (2004) gave the names of 42 species of Dinophysiaceae (including two Citharistes species), eight Amphisoleniaceae and one Oxyphysiaceae species for the southern Gulf of Mexico. Parra-Toriz et al. (2011) mentioned 44 species from the order Dinophysiales found in the southwestern Gulf of Mexico without giving the species names.

In the State of Veracruz, 39 Dinophysiales species have been found previously (Avendaño-Sánchez \& Sotomayor-Navarro, 1982; Hernández-Mendiola, 1988; Suchil-Vilchis, 1990; Zamudio-Resendiz, 1998; Aquino-Cruz, 2002; García-Reséndiz, 2003; Legaría-Moreno, 2003; Estradas-Romero, 2004; Okolodkov et al., 2007, 2011; Parra-Toriz et al., 2011). Zamudio-Resendiz (1998) mentioned 20 Dinophysiales species names; however, she did not give separate species lists for the State of Tamaulipas and the State of Veracruz. Nevertheless, her data are considered in the present article as they all were for Veracruz. In contrast, the article by Licea et al. (2004) was omitted because their records are related to the southern Gulf of Mexico as a whole. For the National Park Sistema Arrecifal Veracruzano (NPSAV), in total, 22 planktonic Dinophysiales species have been reported (Okolodkov et al., 2011; Parra-Toriz et al., 2011); however, only six of them were documented by photographs. In addition, three epiphytic Sinophysis species were encountered and photographed (Okolodkov et al., 2007). In general, the species richness of the Dinophysiales in the NPSAV was considered to be very low (Parra-Toriz et al., 2011).

To fill this gap and to document the Dinophysiales species, both planktonic and benthic (epiphytic), found in the NPSAV, and to provide a key for their identification were the goals of the present study.

\section{MATERIAL AND METHODS}

Phytoplankton samples were taken weekly with a hand net, $20 \mu \mathrm{m}$ mesh and $30 \mathrm{~cm}$ mouth diameter, from 27 sites (stations) throughout the National Park Sistema Arrecifal Veracruzano, southwestern Gulf of Mexico. Collections were made almost every week during the period from May 2005 through April 2008 as part of the monitoring program of the Aquarium of Veracruz (AVM), and two monthly monitoring programs were performed by ICIMAP-UV, from September 2006 through September 2007 (CEP-I), and from April 2007 through May 2008 (CEP-II; Fig. 1, 
Table 1). Site depths ranged from $1.5 \mathrm{~m}$ to $34 \mathrm{~m}$. At each station the net was towed horizontally for $5 \mathrm{~min}$. at the velocity of the boat of ca. 2.5 knots to sample a superficial $30-\mathrm{cm}$ layer. The samples were fixed with a stock formaldehyde solution to a final concentration of $4 \%$ and stored in $100-\mathrm{ml}$ dark plastic bottles. To contrast the cells for an easier search and better photographs, a $0.2 \%$ Trypan Blue water solution was added to water mounts (Lebour, 1925; Taylor, 1978). About 700 samples were analyzed using a Nikon TS100 and an Olympus CKX41 inverted microscope for a Sedgwick-Rafter 1-ml chamber and an Olympus BX51 compound microscope for water mounts. The information about sampling and the laboratory analysis of benthic/epiphytic dinoflagellates was published earlier in detail (Okolodkov et al., 2007). For this study, only Sinophysis species were included, and they were sampled from both seaweeds and seagrasses growing on the sea bottom at St. 3 and 5, and at St. 2 from seaweeds attached to a plastic anchored buoy and its line, in the Aquarium of Veracruz monitoring. The cells were photographed mainly with an Olympus C7070 digital camera (Pl. 1-6). Some samples were examined in a JEOL JSM-7600F scan-

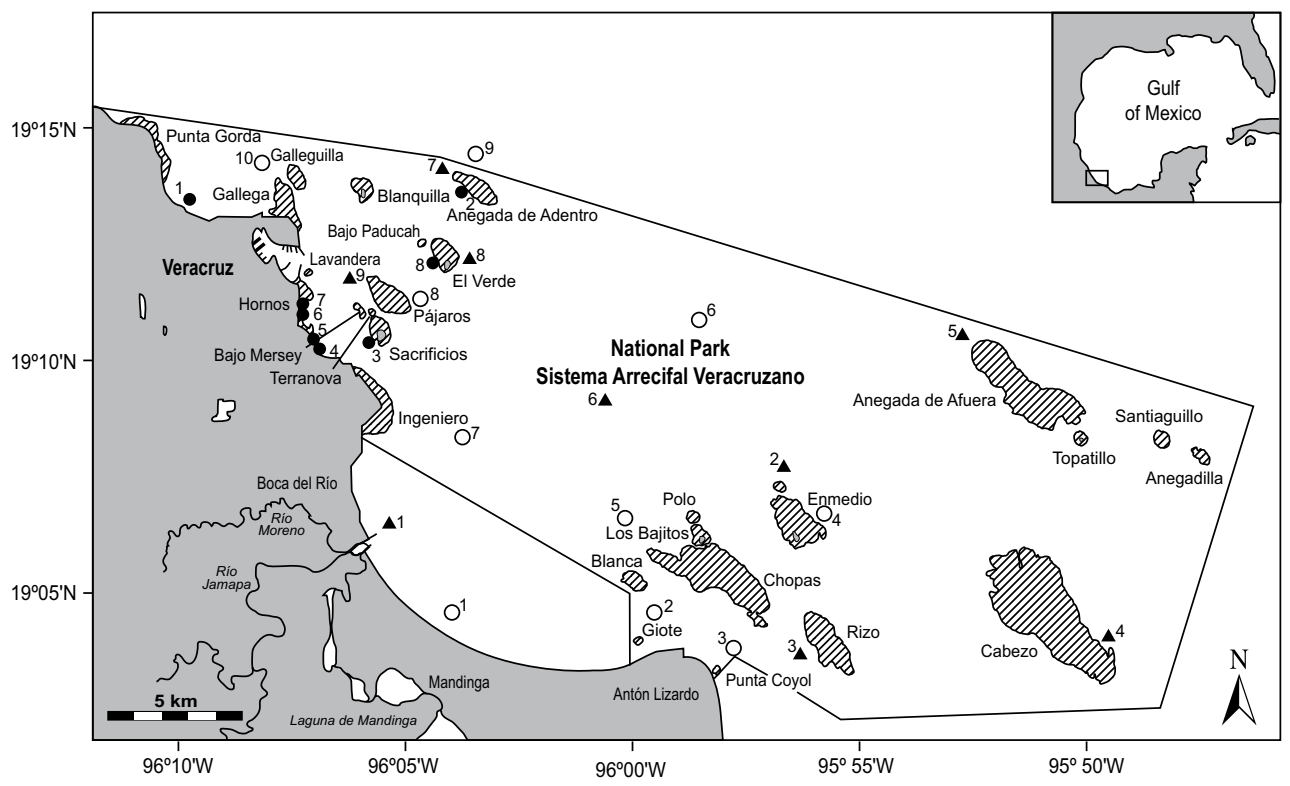

Fig. 1. Sampling sites in the National Park Sistema Arrecifal Veracruzano. Filled circles (the Aquarium of Veracruz monitoring), empty circles (the ICIMAP-UV 2006-2007 monitoring), and triangles (the ICIMAP-UV 2007-2008 monitoring) indicate locations where planktonic dinoflagellates were sampled. Hatched areas are coral reefs. 
Table 1. Sampling sites (stations) in the National Park Sistema Arrecifal Veracruzano, Veracruz, Gulf of Mexico, May 2005 - March 2008.

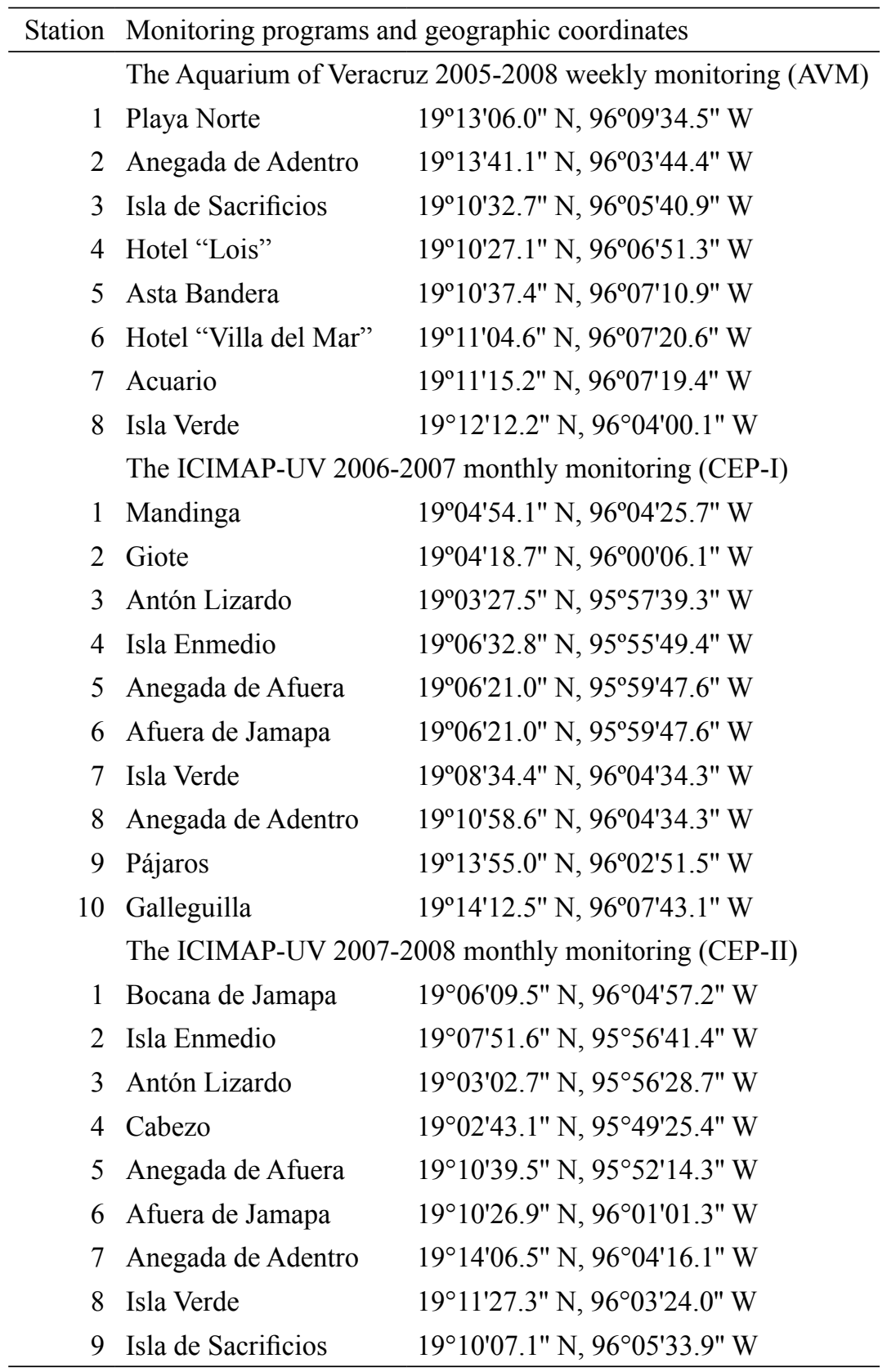


ning electron microscope (SEM) at a working distance of 15 to $21 \mathrm{~mm}$ and a voltage of 1.2 to $5.0 \mathrm{kV}$ after a preliminary wash in distilled water, followed by dehydration in a series of ethanol solutions of increasing concentration (30, 50, 70, 90 and 100\%), air drying on 0.5 " aluminium mounts and sputter coating with gold-palladium using a Polaron SC7640 High Resolution Sputter Coater (Quorum Technologies, Newhaven, East Sussex, U. K.); some micrographs were obtained using a Philips XL-30 environmental SEM (Pl. 7 and 8). Line drawings were made from digital images (Pl. 10-13).

About 90 publications, abstracts and theses on the phytoplankton and dinoflagellates of the Gulf of Mexico were examined, with special emphasis on the state of Veracruz. Extensive old and new literature containing illustrations was analyzed and cited. The works where the species are illustrated are marked with asterisks: an asterisk $\left(^{*}\right)$ indicates line drawings, two asterisks $(* *)$ indicate light micrographs, and three asterisks $(* * *)$ indicate scanning electron micrographs. Relative abundance was given according to the following criteria: extremely rare - found in $<1 \%$ of the analyzed samples only occasionally (less than 25 cells were found in total), rare - encountered in 1 to $10 \%$ of the samples as rare cells, common - seen in 11 to $50 \%$ of the samples (normally as dozens of cells in a Sedgwick-Rafter chamber), and very common - found in $>50 \%$ of the samples (dozens or hundreds of cells per chamber). Abbreviations of authors of scientific names are used according to Brummitt \& Powell (1992), unless they are not listed in the book.

The abbreviations for cell measurements are as follows: Lb - body length measured from the furthest part of the epitheca to the antapex of the hypotheca, not considering appendages or processes (lists or spines); $\mathrm{Lt}$ - total length measured from the furthest part of the epitheca or the anterior cingular list to the furthest part of the posterior or posterior-lateral processes or lists; $\mathrm{Db}$ - maximum cell body depth measured in its widest part in lateral view, not considering the sulcal or cingular lists; Dt - total depth, considering the sulcal and/or cingular lists. Sometimes the cell body width (W) was measured in ventral or dorsal view. All the measurements were performed using the 40x objective to maximize accuracy. To facilitate identification, the terminology is given (Pl. 7 and 8). Other abbreviations are: ACL - anterior cingular list; LSL - left sulcal list; PCL - posterior cingular list; R1 - first rib, R2 - second rib, R3 - third rib; RSL - right sulcal list.

\section{RESULTS}

Below, the keys for identification of eight genera and 38 Dinophysiales species are presented, along with descriptions, light and scanning electron microscope photographs and line drawings. 
Key for identification of the genera of Dinophysiales

1a Cells are very long and thin, with tiny epitheca and elongated hypotheca swollen in its anterior or middle part, with undeveloped sulcal lists (I) Amphisolenia

$1 \mathrm{~b}$ Cells are not long and thin, normally with well developed sulcal lists 2

2a Cells with elaborate left sulcal list (LSL), extending to the antapex or even onto the dorsal side of the hypotheca …................................................................. 3

2b Cells with poorly elaborate LSL not reaching the antapex ............................... 4 3a Cells usually kidney-shaped or suboval in lateral view, with high posterior cingular list (PCL), which forms a cylindrical basket supported by longitudinally oriented ribs, and a funnel-shaped anterior cingular list (ACL) .... (V) Histioneis

3 b Cells usually subglobular in lateral view, with relatively low cingular lists

(VI) Ornithocercus

4a Epitheca very small and narrow, button-like, LSL without supporting ribs (VIII) Sinophysis

$4 \mathrm{~b}$ Epitheca reduced but wide, LSL with supporting ribs 5

5a Epitheca low, usually with ACL located mainly in front of it (II) Dinophysis

$5 \mathrm{~b}$ Epitheca relatively high, with ACL located behind it

6a LSL with a second (fission) rib (R2), the apical pore located close to the cingulum (VII) Phalacroma

6b LSL without R2, the apical pore shifted to the cell apex 7

7a LSL about 0.75-1.0 hypotheca length, the cingulum with two rows of pores (III) Heteroschisma

7b LSL about 0.4-0.5 hypotheca length, the cingulum with one row of pores (IV) Pseudophalacroma

I. Genus Amphisolenia F. Stein

Key for identification of Amphisolenia species

1a Cells with bifurcated hypotheca (1) Amphisolenia bifurcata

$1 \mathrm{~b}$ Cells not bifurcated 2

2a Cells inflated in their anterior part, with a subterminal spinule at elbow (2) Amphisolenia bidentata

$2 \mathrm{~b}$ Cells inflated in their middle part, with no subterminal spine at elbow 3 3a Cells straight, with four antapical spinules (3) Amphisolenia schauinslandii 
$3 \mathrm{~b}$ Cells sigmoid in their posterior part, with two antapical spinules

(4) Amphisolenia schroederi

1. Amphisolenia bifurcata G. Murray et Whitting, 1899 (P1. 1, Fig. 1 and 2; Pl. 10, Fig. 1 and 2).

Cells very long and thin, with a thin "neck", in lateral view slightly inflated in the anterior third (midbody), continuously tapering into a long "tail" (also called caudal appendix or caudal pedunculum; see Balech, 1988: 69), bifurcating at the distal third part of the cell into two asymmetric branch-like processes that form an angle of ca. $45^{\circ}$ between their proximal parts and are parallel or almost parallel between their distal portions directed straight back. These caudal processes are subequal in size, widest and most curved in their middle parts; however, the lower one is slightly longer and thicker. Both processes are slightly swollen in the middle, bearing a subterminal spinule at elbow and terminated with three spinules, positioned on slightly widened tips. The terminal portions of the caudal appendices are slightly thickened toward the end. The anterior half of the cell, in general, is similar to that in A. bidentata; however, the midbody is wider. Lt $975-995 \mu \mathrm{m}(981.4 \pm 6.3$ $\mu \mathrm{m}), \mathrm{W} 35-45 \mu \mathrm{m}(42.0 \pm 4.7 \mu \mathrm{m})$, the caudal appendices span $97-110 \mu \mathrm{m}(103.4 \pm 5.0$ $\mu \mathrm{m}) ; \mathrm{n}=7$.

Records in the State of Veracruz: Zamudio-Resendiz, 1998; Okolodkov et al., 2011. Extremely rare in NPSAV; the species was found only on 1 March 2008 at St. 4 and 6 (CEP-II).

References: Murray \& Whitting, 1899*: 331, pl. 31, fig. 1a-d; Kofoid \& Skogsberg, 1928*: 432, fig. 56(6), pl. 12, fig. 1, 3, 5; Schiller, 1933*: 182, fig. 174 (after Kofoid \& Skogsberg, 1928); Balech, 1962*: 134, pl. 18, fig. 276; Steidinger \& Williams, 1970**: pl. 2, fig. 6; Tester \& Steidinger, 1979**: 27, fig. 55.

\section{Amphisolenia bidentata Schröd., 1900 (Pl. 1, Fig. 3-5; Pl. 10, Fig. 3 and 4).}

Cells very long and thin, slightly sigmoid, with a thin "neck", in lateral view slightly inflated in the anterior quarter (midbody), continuously tapering into a long "tail", which is slightly curved upward and terminated with three spinules, one of which (subterminal, located at elbow) faces downward and the other two (terminal, located symmetrically on both sides of the "tail") upward; distal part of the "tail" is slightly widened, truncate and dorsoventrally compressed. The "head" is small, consisting of the epitheca and the cingulum, is positioned obliquely in relation to 
the longitudinal axis of the cell, looking anteriorly-upward. The epitheca is slightly convex, separated from the cingulum by a rather wide list supported by several ribs. PCL continues into the sulcal lists along both sides of the "neck", reaching the "midbody", where it is widest. Lt 800-870 $\mu \mathrm{m}(851.2 \pm 15.6 \mu \mathrm{m}), \mathrm{W} 15-24 \mu \mathrm{m}(19.1 \pm 2.4$ $\mu \mathrm{m}) ; \mathrm{n}=39$.

Morphological note. A specimen $640 \mu \mathrm{m}$ long and $20 \mu \mathrm{m}$ wide, with a gradually tapering hypotheca ending with a thin theca with an acute end without spines, presumably belonging to A. bidentata (Pl. 1, Fig. 5), was found at St. 4 on 1 March 2008 (CEP-II).

Records in the State of Veracruz: Zamudio-Resendiz, 1998; Figueroa-Torres \& Weiss-Martínez, 1999; Aquino-Cruz, 2002**; Okolodkov et al., 2011. Rare in NPSAV (Feb., March, May, July, Dec.); the most common species of the genus Amphisolenia in the study area.

References: Schröder, 1900*: 20, 35, pl. 1, fig. 16a, c; Kofoid \& Skogsberg, 1928*: 409, fig. 54(1-4), 55, 56(1); Schiller, 1933*: 178, fig. 169a-e (after Kofoid \& Skogsberg, 1928); Rampi, 1940*: 24, fig. 44; Silva, 1955*: 124, pl. 2, fig. 1-4; Yamaji, 1966*: 72, pl. 33, fig. 11; Halim, 1967**: 704, pl. 1, fig. 2, pl. 2, fig. 15; Steidinger et al., 1967*: pl. 2, fig. a; Wood, 1968*: 18, fig. 19; Steidinger \& Tangen, 1996*: 426, pl. 10; Steidinger \& Williams, 1970**: pl. 2, fig. 5; Taylor, 1976*: 28, pl. 2, fig. 21, 22, pl. 3, fig. 21b, 22b; Balech, 1977*: 26, fig. 1-14, 1988*: 69, pl. 17, fig. 2, 3, 13; Pesantes-Santana, 1978*: 6, pl. 1, fig. 4-7; Tester \& Steidinger, 1979**: 27, fig. 54; Hernández-Becerril, 1988a**: 188, pl. 1, fig. 1-3; 1988b**: 10, fig. 52, 53; Licea et al., 1995****: 17, pl. 1, fig. 2a-c, pl. 17, fig. 3; Hernández-Becerril et al., 2008**: 10, fig. 52, 53; Esqueda-Lara \& Hernández-Becerril, 2010**: 170, fig. 163a-d.

3. Amphisolenia schauinslandii Lemmermann, 1899 (Pl. 1, Fig. 6 and 7; Pl. 7, Fig. 1 and 2; Pl. 10, Fig. 5 and 6).

Cells long and thin, fusiform, with a thin "neck" and a straight hypotheca, in lateral view inflated in its middle part (midbody), gradually diminishing backward and only slightly widening at the truncate posterior end and bearing four spinules, directed posteriorly and almost equally distanced. Lt 415-440 $\mu \mathrm{m}(427.5 \pm 17.7 \mu \mathrm{m})$, W 20-25 $\mu \mathrm{m}(22.5 \pm 3.5 \mu \mathrm{m}) ; \mathrm{n}=2$.

Records in the State of Veracruz: Okolodkov et al., 2011. Extremely rare in NPSAV; two cells were found on 1 March 2008 at St. 4 and 6 (CEP-II). This is the first documented record of this species, not considering A. cf. schauinslandi mentioned by Zamudio-Resendiz (1998). 
References: Lemmermann, 1899*: 350, pl. 1, fig. 18, 19; Kofoid \& Skogsberg, 1928*: 374, fig. 49(4), pl. 7, fig. 1-8; Schiller, 1933*: 169, fig. 155; Wood, 1968*: 21, fig. 31; Balech, 1988*: 71, pl. 17, fig. 9-11.

4. Amphisolenia schroederi Kof., 1907 (P1. 1, Fig. 8 and 9; P1. 10, Fig. 7 and 8).

Cells long and thin, fusiform, with a thin "neck" and slightly sigmoid posterior part of the hypotheca, in lateral view inflated in its middle part (midbody), gradually diminishing backward, bearing two terminal spinules at the antapex, directed posteriorly. Lt $312 \mu \mathrm{m}, \mathrm{W} 19 \mu \mathrm{m} ; \mathrm{n}=1$.

Morphological note. The specimen from Veracruz is also similar to A. curvata Kof., 1907 by the swelling in the middle of the cell, the presence of two terminal spinules, and curved posterior end of the cell. However, in A. curvata the "tail" is gradually curved to the dorsal side of the cell, and in A. schroederi the curvature is sigmoid and not so pronounced. Unlike the figures by Kofoid (1907) and Taylor (1976), who pictured the cells with a less clearly differentiated midbody, our specimen has a midbody much more differentiated from the rest of the cell. Our cell is quite different in a number of features from the specimen of $A$. schroederi illustrated and described by Balech (1962).

The first reliable record for the State of Veracruz. Extremely rare in NPSAV; the only cell was found on 26 October 2006 at St. 3 (AVM). It is the second record of this species in the Gulf of Mexico. Previously it was observed only at one (unknown) sampling site in the southern Gulf of Mexico (Licea et al., 2004) and also by Balech (1967b).

References: Kofoid, 1907*: 201, pl. 13, fig. 81; Kofoid \& Skogsberg, 1928*: 400, fig. 49(15), pl. 10, fig. 2-4; Schiller, 1933*: 176, fig. 165; Balech, 1962*: 132, pl. 18, fig. 271.

\section{Genus Dinophysis Ehrenberg}

Key for identification of Dinophysis species

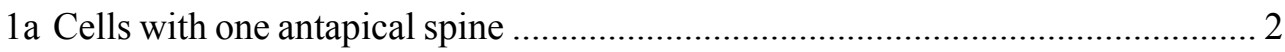

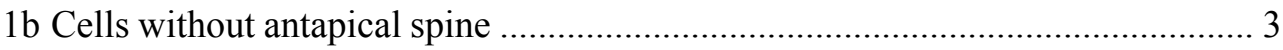

2a Cells small, 40-50 $\mu \mathrm{m}$ long, with strongly areolated theca, subtriangular hypotheca and a short antapical spine (1) Dinophysis capitulata 

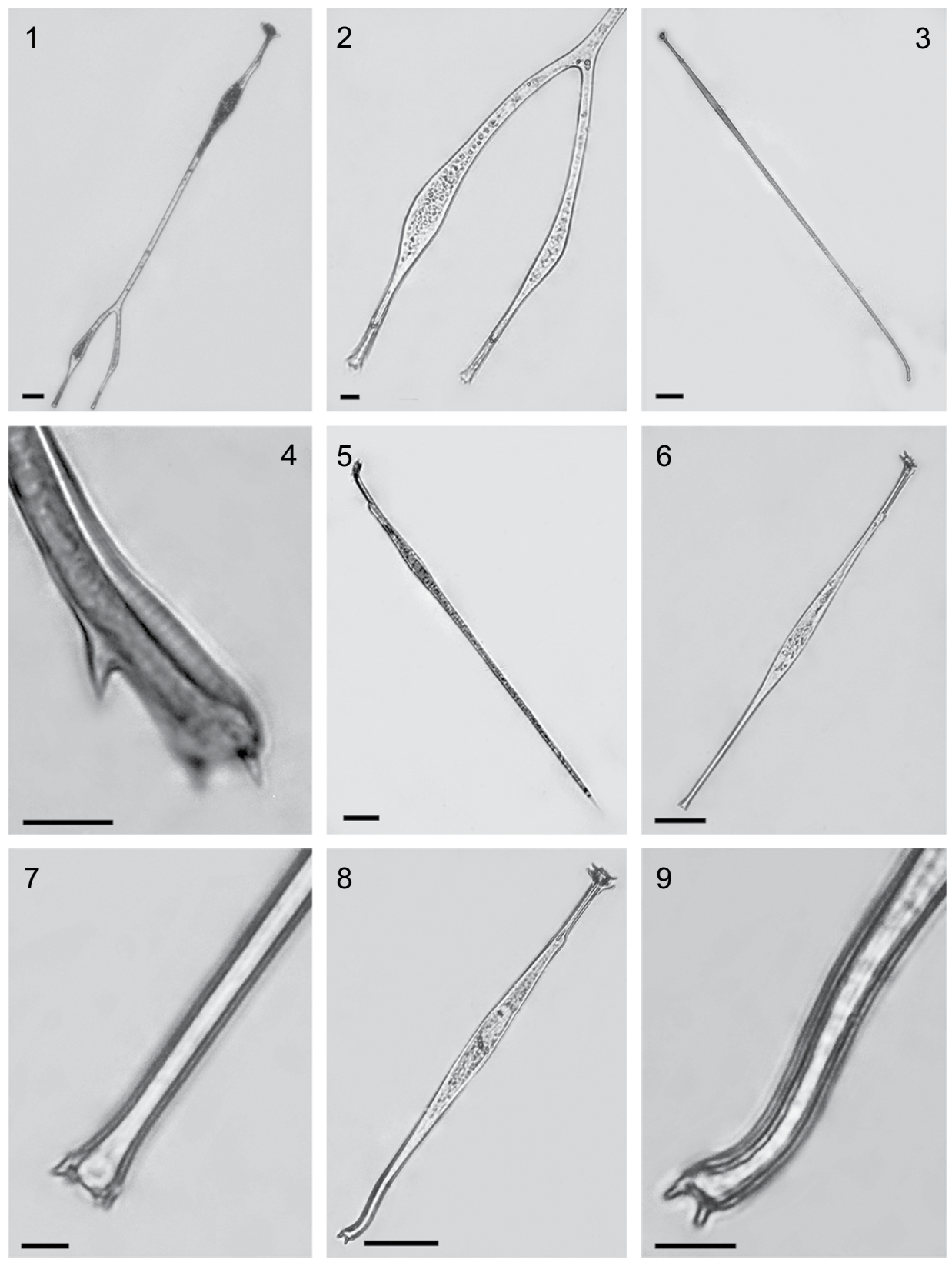

Plate 1. Fig. 1 and 2. Amphisolenia bifurcata. Fig. 3-5. Amphisolenia bidentata (Fig. 5 presumably a young cell with an atypical pointed antapex). Fig. 6 and 7. Amphisolenia schauinslandii. Fig. 8 and 9. Amphisolenia schroederi. Scale bars: $10 \mu \mathrm{m}$ in Fig. 2, 4, 7 and 9; $50 \mu \mathrm{m}$ in Fig. 1, 3, 5, 6 and 7. 
2b Cells medium-sized, 60-100 $\mu \mathrm{m}$ long, suboval, with smooth theca and relatively long antapical spine

(2) Dinophysis hastata

3a Cells with a conical projection directed posteriorly-ventrally

(3) Dinophysis caudata

3b Cells without posterior projection ............................................................. 4

4a Cells strongly elongated, with nearly straight ventral margin in lateral view, narrowly rounded posterior part of the hypotheca and a long LSL almost equal to the cell body length (4) Dinophysis schroederi $4 \mathrm{~b}$ Cells oval or suboval in lateral view, with convex ventral margin, widely rounded posterior part of the hypotheca and LSL of about $0.65-0.70$ the cell body length ... 5

5a Distance between R2 and R3 is about twice that between R1 and R2, with no list behind R3

(5) Dinophysis cf. similis

$5 \mathrm{~b} \mathrm{R} 1, \mathrm{R} 2$ and R3 equally or subequally distanced, a list is present behind R3 ...... 6 6a Cells medium-sized, 45-60 $\mu \mathrm{m}$ long, with areolated thecae, LSL having the same width in its anterior and posterior parts

(6) Dinophysis ovum $6 \mathrm{~b}$ Cells small, 28-38 $\mu \mathrm{m}$ long, with smooth thecae, LSL increasing in width from R1 backward (7) Dinophysis cf. exigua

1. Dinophysis capitulata Balech, 1967 (Pl. 2, Fig. 1; Pl. 10, Fig. 9).

Cells subtriangular, strawberry-shaped, usually with a posteriorly attenuated hypotheca, terminating with a coarse triangular or subtriangular spine. In apical view, cells are almost circular. The theca is coarsely areolated. The cell is widest at the level of PCL. The cingulum is noticeably concave. The cingular lists are directed more laterally than anteriorly, supported by numerous coarse ribs that reach only the mid-width of the lists. The sulcal lists are moderately wide. The distance between $\mathrm{R} 2$ and R3 is slightly longer than between R1 and R2. R3 is the thickest, straight or somewhat curved, slightly longer than R2. RSL continues well behind the base of R2 but does not reach R3. Lb 37.5-42.5 $\mu \mathrm{m}(40.0 \pm 1.8 \mu \mathrm{m})$, Lt 42.5-50 $\mu \mathrm{m}(44.5 \pm 2.5$ $\mu \mathrm{m}), \mathrm{Db} 33.5-41.5 \mu \mathrm{m}(36.7 \pm 2.1 \mu \mathrm{m})$, Dt 40-47.5 $\mu \mathrm{m}(42.7 \pm 2.3 \mu \mathrm{m}) ; \mathrm{n}=14$.

A new record for the southern Gulf of Mexico and the second known record for the entire Gulf (see Steidinger et al., 2009). Rare in NPSAV (Apr., Oct.).

References: Balech, 1967a*: 90, pl. 2, fig. 25-31; 1988*: 56, pl. 14, fig. 1-3.

2. Dinophysis hastata F. Stein, 1883 (Pl. 2, Fig. 2 and 3; Pl. 10, Fig. 10). Syn.: D. odiosa (Pavill.) L. S. Tai et Skogsb., 1934: 448; (?) Phalacroma hastatum Pavill., 1909: 283, fig. 4. 
Cells are irregularly ovoid or sometimes regularly ovoid, with a subtruncate anterior end and broadly or narrowly rounded posterior end, terminated with a strong triangular antapical spine directed posteriorly-ventrally or in rare cases backward, often supported by a thick central rib. The cell is widest at the level of R3. Epitheca is very short, flat or slightly convex. The hypotheca is slightly asymmetrical in relation to the longitudinal axis of the cell, more narrowly rounded than the epitheca. The cingulum is slightly convex. The cingular lists are wide, directed laterally-anteriorly; ACL is supported by numerous ribs. R1, R2 and R3 are equally spaced or with the longer distance between R2 and R3 (up to 1.5 times the distance between $\mathrm{R} 1$ and R2). R3 is the longest and the thickest, almost straight or slightly curved backward, almost reaching the level of the antapex. LSL is wide, often finely reticulate, RSL terminates at R3. Lb 45-67.5 $\mu \mathrm{m}(52.6 \pm 9.8 \mu \mathrm{m})$, Lt 60-100 $\mu \mathrm{m}(71.0 \pm 14.0$ $\mu \mathrm{m}), \mathrm{Db} 36.5-57.5 \mu \mathrm{m}(44.4 \pm 8.4 \mu \mathrm{m})$, Dt 47.5-82.5 $\mu \mathrm{m}(59.0 \pm 13.4 \mu \mathrm{m}) ; \mathrm{n}=18$.

Taxonomic note. Judging from the wide morphological variation and the recently published data on molecular biology, it is a collective species, or the Dinophysis hastata group (also called the "hastata" group), hiding a number of cryptic species (Kofoid \& Skogsberg, 1928: 266; Abé, 1967a: 77; Balech, 1967a: 282; Norris \& Berner Jr., 1970: 169; Gómez et al., 2011a: 404); the "hastata" group includes at least 21 species (Norris \& Berner Jr., 1970: 146). Based on the material from the NPSAV, variation is most visible in cell shape, the position and shape of the antapical spine, length and direction of $\mathrm{R} 3$, the distance between $\mathrm{R} 2$ and $\mathrm{R} 3$ and the longitudinal expansion of LSL. Halim (1967: 726, pl. 4, fig. 47) presented D. hastata under the name of $D$. monacantha Kof. et Skogsb., which I consider a misidentification. The diagnosis of the latter includes the statement about the cell shape: "body rounded trapeziform in lateral outline, deepest in or just behind the middle" (Kofoid \& Skogsberg, 1928: 283, $37(2,3)$; that does not correspond to the specimen illustrated by Halim (1967), which is suboval and almost symmetrical in relation to the longitudinal axis of the cell.

Records in the State of Veracruz: Avendaño-Sánchez \& Sotomayor-Navarro, 1982; Zamudio-Resendiz, 1998; Okolodkov et al., 2011. Extremely rare in NPSAV; the species was found only on 26 October 2006 at St. 3 (AVM).

References: Stein, 1883*: pl. 19, fig. 12; Paulsen, 1908*: 13, fig. 9 (after Stein, 1883); Lebour, 1925*: 83, fig. 21e (after Stein, 1883); Kofoid \& Skogsberg, 1928*: 261, fig. 32(1-17), 33(1-3); Schiller, 1933*: 138, fig. 131a-f; Böhm, 1936*: 18, fig. 6a-h; Rampi, 1940*: 22, fig. 40; Silva, 1956*: 17, pl. 1, fig. 26, 27 (as D. diegensis); Yamaji, 1966*: 71, pl. 32, fig. 17; Abé, 1967a*: 76, fig. 25; Halim, 1967**: 726 (misidentified as D. monacantha); Norris \& Berner Jr., 1970*: 165, fig. 46-59; Steidinger \& Williams, 1970**: pl. 17, fig. 48; Taylor, 1976*: 37, pl. 5, fig. 52-55; Dodge, 1982* 
***: 49, fig. 4C, pl. 2, fig. g; 1985***: 21; Balech, 1988*: 54, pl. 13, fig. 1-3; Hallegraeff \& Lucas, 1988***: fig. 11, 15, 16, 26b; Steidinger \& Tangen, 1996*: 433, pl. 12; Hansen et al., 2001**: 29, pl. 2, fig. A; Larsen \& Nguyen, 2004**: 67, pl. 2, fig. 1-2; Hernández-Becerril et al., 2008**: 6, fig. 15; Esqueda-Lara \& HernándezBecerril, 2010**: 151, fig. 144a-c.

\section{3a. Dinophysis caudata Saville-Kent, 1881 var. pedunculata (Schmidt) Schröd.,} 1906 (Pl. 2, Fig. 4; Pl. 7, Fig. 3; Pl. 10, Fig. 11). Syn.: D. homunculus F. Stein, 1883, pro parte: 24, pl. 21, fig. 8; Dinophysis diegensis Kof., 1907 (Univ. Calif. Publ. Zool. 3, 13): 313, pl. 33, fig. 57-61; Dinophysis diegensis f. contracta J. Schill., 1933: 152, fig. 144d.

Cells are irregularly trapezoidal, angulated, with a well separated hypothecal pointed conical projection directed posteriorly-ventrally, up to 0.4 of the body length, which can bear 1 to 3 knob-like spinules. The dorsal contour is straight or slightly concave along the anterior part of the hypotheca and convex along its middle part. The ventral contour is straight in general, slightly undulate. The cell is widest at the base of R3, distinctly tapering anteriorly. The theca is coarsely areolated. The cingulum is noticeably concave. The cingular lists are directed laterally-anteriorly and supported by ribs. The sulcal lists are wide, often reticulate. The LSL is wide and relatively long, supported by three long, slightly curved ribs spaced equally apart; R3 is the longest. The distal margins of the LSL form almost a right angle. The RSL is wedge-shaped, terminating at R3 and being very narrow between R2 and R3. Paired cells resulting from binary fission (asexual reproduction) are common. Lb 77.5-90 $\mu \mathrm{m}(86.8 \pm 3.3 \mu \mathrm{m})$, Lt 85-101 $\mu \mathrm{m}(96.9 \pm 4.0 \mu \mathrm{m})$, Db 42.5-48.5 $\mu \mathrm{m}$ (46.2 $\pm 1.6 \mu \mathrm{m})$, Dt 52.5-68.5 $\mu \mathrm{m}$ 63.1 $\pm 3.8 \mu \mathrm{m}) ; \mathrm{n}=31$.

Morphological note. Three gametes, previously known as Dinophysis diegensis Kof., were observed: small cells, Lb 55-62.5 $\mu \mathrm{m}(57.8 \pm 4.1 \mu \mathrm{m})$, Lt 62.5-71 $\mu \mathrm{m}$ $(65.3 \pm 4.9 \mu \mathrm{m}), \mathrm{Db} 26-30 \mu \mathrm{m}(27.8 \pm 2.0 \mu \mathrm{m}), \mathrm{Dt} 35.7 \pm 2.9$ (Pl. 2, Fig. 7 and 8). Earlier it was hypothesized (Moita \& Sampayo, 1993; Reguera et al., 1995; Reguera \& González-Gil, 2001) and experimentally shown (Reguera et al., 2007) that $D$. diegensis and $D$. caudata are synonymous. Gametes had slightly tapering anterior sides, pointed posteriorly, without a hypothecal projection or with a well marked tubular process of up to 0.25 of the cell body length, with the longest R1 and narrower sulcal lists. Dinophysis caudata is a rather variable species, which resulted in the description of a number of forms and varieties. I follow Balech's (1951) opinion, distinguishing only var. pedunculata and var. abbreviata within $D$. caudata. 
Records in the State of Veracruz: Avendaño-Sánchez \& Sotomayor-Navarro, 1982 (as D. homunculus); Suchil-Vilchis, 1990*; Zamudio-Resendiz, 1998 (also, as D. diegensis Kof.); Figueroa-Torres \& Weiss-Martínez, 1999; Aquino-Cruz, 2002* **; Estradas-Romero, 2004; Tejeda-Hernández, 2005**; Hernández-Becerril et al., 2008; Okolodkov et al., 2011. In NPSAV it is the most common species of the genus Dinophysis. It was observed throughout the year.

References: Stein, 1883*: pl. 21, fig. 1, 2, 5, non 3, 4, 6-8 (as D. homunculus); Paulsen, 1908*: 19, fig. 20 (left, not right; after Stein, 1883; as D. homunculus); 1931*: 34, fig. 19; Pavillard, 1916*: 56, fig. 15A (as D. homunculus type), 57, pl. 3, fig. 2 (as D. diegensis Kof. var. caudata nov. var.); Lebour, 1925*: 82, fig. 21c; Martin, 1929*: 21, pl. 4, fig. 14; Tai \& Skogsberg, 1934*: 453, fig. 9A-K, 10D-F; Curl, 1959*: 305, fig. 110 (erroneously written as 100 on p. 320); Böhm, 1935*: 277, fig. 4a-i; 1936*: 20, fig. 7a-c; Rampi, 1940*: 23, fig. 41; Balech, 1951*: 6, pl. 1, fig. 1, 10, pl. 3, fig. 45-68, pl. 4, fig. 73-76; Yamaji, 1966*: 70, pl. 32, fig. 13 and 14 (as D. homunculus and D. homunculus f. pedunculatus Schmidt; also, as D. diegens Kofoid and D. diegens Kofoid var. caudata Pavillard, both misspelled); Halim, 1967**: 726, pl. 4, fig. 48; Taylor, 1976*: 34, pl. 6, fig. 59; Tester \& Steidinger, 1979**: 30, fig. 74; Dodge, 1985***: 18 (fig. below, not above where D. tripos is illustrated); Hernández-Becerril, 1988a**: 192, pl. 5, fig. 34, 35 (a gamete; as Dinophysis sp.); Fukuyo et al., 1990*****: 36, fig. A-E; Delgado \& Fortuño, 1991*: fig. 4E; Licea et al., 1995**: 19, pl. 6, fig. 4; Steidinger \& Tangen, 1996*: 431, pl. 12; Hansen et al., 2001**: 28, pl. 2, fig. E; Faust \& Gulledge, 2002******: 26, pl. 13, fig. 1-6; Larsen \& Nguyen, 2004**: 65, pl. 1, fig. 1-5; Alonso-Rodríguez et al., 2008**: 133; Hernández-Becerril et al., 2008*****: 3, fig. 6, 7, 9, 10 (also as D. diegensis); Al-Kandari et al., 2009**: 151, pl. 3, fig. E-H (p. 300); Esqueda-Lara \& Hernández-Becerril, 2010*****: 145, fig. 138a-c.

3b. Dinophysis caudata var. abbreviata Jörg., 1923 (P1. 2, Fig. 5 and 6; Pl. 11, Fig. 1 and 2). Syn.: Dinophysis homunculus f. ventricosa Pavill., 1916: 56, fig. 15B; D. caudata f. acutiformis Kof. et Skogsb., 1928: 231.

Cells are irregularly ovoid, with rounded angles and a poorly separated hypothecal conical projection directed posteriorly-ventrally, which can bear 1 to 3 knob-like spinules. The dorsal contour is straight in the proximal part of the hypotheca. The cell is widest at the level of R3, tapering anteriorly. R1, R2 and R3 are almost equal in length. The LSL is wide but narrower than in var. pedunculatum. The RSL is wedge-shaped, terminating at R3 and being very narrow between R2 and R3. The distal margin of the LSL is broadly rounded. Lb $60-90 \mu \mathrm{m}(73.0 \pm 5.9$ 
Okolodkov: Dinophysiales of the National Park Sistema Arrecifal Veracruzano
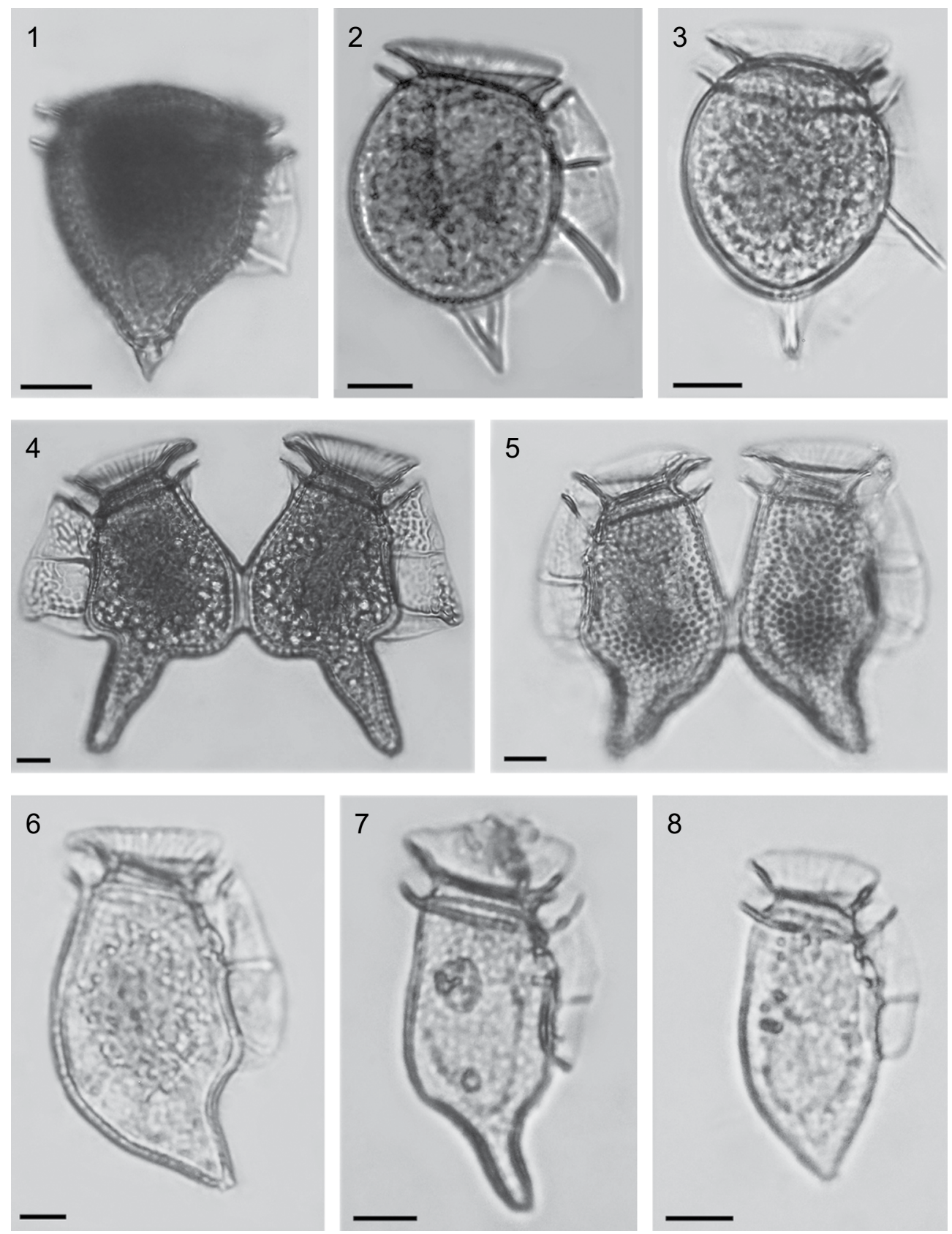

Plate 2. Fig. 1. Dinophysis capitulata. Fig. 2 and 3. Dinophysis hastata. Fig. 4. Dinophysis caudata var. pedunculata. Fig. 5 and 6. Dinophysis caudata var. abbreviata. Fig. 7 and 8. Presumably gametes of Dinophysis caudata. Scale bar: $10 \mu \mathrm{m}$. 
$\mu \mathrm{m})$, Lt 70-97.5 $\mu \mathrm{m}(81.6 \pm 6.2 \mu \mathrm{m})$, Db 27.5-47.5 $\mu \mathrm{m}(40.0 \pm 3.9 \mu \mathrm{m})$, Dt 35-67.5 $\mu \mathrm{m}$ $(50.4 \pm 5.8 \mu \mathrm{m}) ; \mathrm{n}=31$.

Taxonomic note. Although Kofoid \& Skogsberg (1928: 227) believe that $D$. caudata f. acutiformis has «a rather uncertain systematic status», I consider it synonymous to var. abbreviata.

Records in the State of Veracruz: Legaría-Moreno, 2003 (as D. caudata var. ventricosa Pavillard). Rather common in NPSAV, most frequent in July.

References: Rampi, 1940*: 24, fig. 42 (as D. caudata f. acutiformis Kof. et Skogsb.); Yamaji, 1966*: 70, pl. 32, fig. 15 (as D. homunculus f. ventricosa Pavillard); Steidinger et al., 1967*: pl. 2, fig. b (as D. caudata var. B); Pesantes-Santana, 1978*: 20, pl. 14, fig. 4-6.

\section{Dinophysis schroederi Pavill., 1909 (P1. 3, Fig. 1; P1. 11, Fig. 3).}

Cells are asymmetrically subovoid, elongated, about 1.8 times longer than they are wide, with narrowly rounded epitheca and the posterior part of the hypotheca without antapical processes. The theca is coarsely areolated. The cell is widest at the level of the mid-distance between R2 and R3. The epitheca is very short and small, slightly convex. The hypotheca is asymmetrical in relation to the longitudinal axis of the cell, with a narrowly rounded posterior part. Its dorsal margin is well rounded at the level beween R2 and R3 and slightly convex toward both ends, and its ventral margin is straight or almost straight between R1 and R3. The cingulum is slightly convex or flat. The cingular lists are relatively wide, directed laterally-anteriorly. LSL is long and broad. RSL is subtrapezoidal, terminating just behind the base of R2. Both sulcal lists can be faintly or coarsely reticulate. The distance between R2 and R3 is about 1.5 times the distance between R1 and R2. R3 is the thickest and the longest, curved backward at its distal part, directed laterally-posteriorly in general, about 1.8 times longer than R2, almost reaching the level of the antapex. Lb $67.5 \mu \mathrm{m}$, Lt $70 \mu \mathrm{m}$, Db $41.5 \mu \mathrm{m}$, Dt $56.5 \mu \mathrm{m} ; \mathrm{n}=1$.

A new record for the State of Veracruz. Extremely rare in NPSAV; the species was found only on 10 May 2005 at St. 2 (AVM).

References: Pavillard, 1909*: 284, fig. 5; 1916*: 58, pl. 3, fig. 5; Kofoid \& Skogsberg, 1928*: 257, fig. 31(6); Schiller, 1928*: 73, fig. 33; 1933*: 133, fig. 125; Rampi, 1940*: 21, fig. 28; Yamaji, 1966*: 70, pl. 32, fig. 6; Balech, 1971a*: 53, fig. 47-53; Delgado \& Fortuño, 1991*: fig. 4C.

5. Dinophysis cf. similis Kof. et Skogsb., 1928 (Pl. 3, Fig. 2; Pl. 11, Fig. 4). 
Cells are of moderate size, suboval, markedly asymmetrical in relation to the longitudinal axis of the cell, convex dorsally and posteriorly and almost straight between the cingulum and R3 in lateral view, with strongly areolated theca. Epitheca is low, widely rounded. Hypotheca is very broadly rounded. LSL is long, terminating in about 3/4 the cell length, located closer to the antapex, with a rounded posterior margin and no list behind R3. Both R2 and R3 are curved anteriorly in their distal parts. The distance between R2 and R3 is about twice that between R1 and R2. RSL is rather small, with a rounded margin, ending in mid-distance between R2 and R3. Lb $60 \mu \mathrm{m}$, Db $53.5 \mu \mathrm{m}$, Dt $61 \mu \mathrm{m} ; \mathrm{n}=1$.

Morphological note. In the original description of D. similis, Kofoid \& Skogsberg (1928: 247) stated that R3 was "absent or rudimentary (very short)". Our specimen fits rather well the illustrations of two cells in lateral view by Balech (1988); however, our specimen differs by (1) the wider anterior part of the cell, (2) a more rounded RSL, (3) a noticeably areolated theca, (4) the presence of R3, and probably (4) by the absence of strong ribs supporting ACL.

A new record for the State of Veracruz. Extremely rare in NPSAV; the species was found only on 26 October 2006 at St. 3 (AVM).

References for Dinophysis similis: Kofoid et Skogsberg, 1928*: 247, fig. 31(1, 2); Balech, 1962*: 122, pl. 17, fig. 248-250 (as D. simplex n. sp.; non D. simplex Böhm, 1933: 15, fig. 1a, b); 1988*: 42, pl. 6, fig. 1-4.

\section{Dinophysis ovum F. Schütt, 1895 (Pl. 3, Fig. 3; P1. 11, Fig. 5).}

Cells are asymmetrically ovoid or subovoid, with a narrowly rounded epitheca and a broadly rounded hypotheca, without antapical processes. The theca is coarsely areolated. The cell is widest at the level of R3. The epitheca is very short and small, slightly convex. The hypotheca is asymmetrical in relation to the longitudinal axis of the cell, with the antapex slightly shifted ventrally. The cingulum is slightly convex or flat. The cingular lists are relatively wide, directed laterally-anteriorly. LSL is moderately broad. RSL is subtriangular, terminating at the base of R2 or just behind it. Both sulcal lists can be faintly or coarsely reticulate. The distance between R2 and R3 is usually slighly longer, sometimes about 1.5 times the distance between R1 and R2. R3 is the thickest and the longest, straight or somewhat curved, directed laterally-posteriorly or laterally, slightly longer than R2. Lb 42.5-52.5 $\mu \mathrm{m}(46.8 \pm 2.8 \mu \mathrm{m}), \mathrm{Lt} 47.5-52.5$ $\mu \mathrm{m}(52.1 \pm 3.1 \mu \mathrm{m}), \mathrm{Db} 34-42 \mu \mathrm{m}(36.8 \pm 2.1 \mu \mathrm{m}), \mathrm{Dt} 41.5-52 \mu \mathrm{m}(45.8 \pm 2.6 \mu \mathrm{m}) ; \mathrm{n}=32$.

Affinities. The species is very similar to the toxic $D$. fortii; however, in general, the cells are shorter, less asymmetrical in relation to the longitudinal axis of the 
cell, and the base of R3 is usually located further from the antapex, at the distance of $3 / 5-2 / 3$ of the cell length, while in $D$. fortii at about $2 / 3$ (for comparison, see $D$. fortii in Tai \& Skogsberg, 1934: 439, fig. 5A-D; Abé, 1967a: 54, fig. 13; Balech, 1988: 43, pl. 6, fig. 19; Hallegraeff \& Lucas, 1988: fig. 29b; Fukuyo et al., 1990: 38, fig. A-F; Larsen \& Moestrup, 1992: 6, fig. 4a-c).

Records in the State of Veracruz: Avendaño-Sánchez \& Sotomayor-Navarro, 1982; Zamudio-Resendiz, 1998. Rare in NPSAV (May, June, Aug.).

References: Schütt, 1895*: pl. 1, fig. 6; Paulsen, 1908*: 17, fig. 16 (after Schütt, 1895); Pavillard, 1916*: 58, pl. 3, fig. 3; Lebour, 1925*: 81, pl. 12, fig. 3; Schiller, 1928*: 73, fig. 33; 1933*: 116, fig. 109 (after Lebour, 1925); Martin, 1929*: 21, pl. 2, fig. 10; Rampi, 1940*: 20, fig. 33; Balech, 1962*: 125, pl. 16, fig. 205-213; Yamaji, 1966*: 69, pl. 32, fig. 1; Abé, 1967a*: 50, fig. 10a-p; Steidinger \& Williams, 1970**: pl. 17, fig. 49; Pesantes-Santana, 1978*: 20, pl. 14, fig. 8; Dodge, 1982*: 53, fig. 3J; Licea et al., 1995*: 20, pl. 20, fig. 14; Hernández-Becerril et al., 2008**: 6, fig. 20.

\section{Dinophysis cf. exigua Kof. et Skogsb., 1928 (Pl. 3, Fig. 4; Pl. 11, Fig. 6).}

Cells are small, subglobal, somewhat asymmetrical in relation to the longitudinal axis of the cell, slightly ventrally compressed along LSL in lateral view. Thecal ornamentation is not distinguishable. The epitheca is very small, widely rounded. The cingulum is relatively narrow, slightly concave dorsally. The hypotheca is very broadly rounded posteriorly. LSL is relatively short, terminating about 0.6 of the cell length, continuously widening from R1 through R3. R1, R2 and R3 are equally distanced, R2 being longer than R1 but shorter than R3. RSL is as long as LSL but narrower, terminating at the base of R3. Lb 30-40 $\mu \mathrm{m}(35.0 \pm 7.1 \mu \mathrm{m}), \mathrm{Db} 27.5-35 \mu \mathrm{m}$ (31.3 $\pm 6.0 \mu \mathrm{m})$, Dt 36.5-45 $\mu \mathrm{m}(40.1 \pm 6.0 \mu \mathrm{m}) ; \mathrm{n}=2$.

Morphological note. The species was originally described from the eastern tropical Pacific. The main difference between our cell and the cells described and illustrated by both Kofoid \& Skogsberg (1928) and Balech (1967a) is that the former has the LSL ribs equally distanced, and the latter has the distance between R2 and R3 about twice that between R1 and R2. Furthermore, these authors did not observe RSL, and in our specimen it was distinguishable, although faint. Another difference is that R3 is directed laterally in our cell and laterally-posteriorly in the specimens pictured by the other authors.

A new record for the State of Veracruz. Rare in NPSAV; the species was found only on 26 October 2006 at St. 3 (AVM), 29 May and 7 October 2007 at St. 7 (CEP-II). 
References for Dinophysis exigua: Kofoid \& Skogsberg, 1928*: 239, fig. 30; Balech, 1967a*: 86, pl. 1, fig. 4-12.

III. Genus Heteroschisma Kof. et Skogsb. ex J. Schill.

Heteroschisma sp. (P1. 3, Fig. 5; P1. 11, Fig. 7).

Cell almost regularly oval, broadly rounded anteriorly and more narrowly rounded posteriorly, without any antapical processes. The theca is covered by numerous small poroids. Epitheca is rather long, about half the length of the hypotheca. Hypotheca is slightly compressed in the sulcal area. Cingulum is rather wide, about 1/7 of the cell length, slightly convex. Cingular lists are laterally directed. Sulcal lists are narrow. LSL is rather long, supported by a thin, straight R3, situated rather close to the antapex; R2 is undistinguishable. RSL seems to be short, subtriangular. Lb $37.5 \mu \mathrm{m}$, Db $31.5 \mu \mathrm{m}$, Dt $35 \mu \mathrm{m}$; $\mathrm{n}=1$.

Morphological note. Our cell is similar to that illustrated by Balech (1988: 38, pl. 5, fig. 1, 2), who failed to identify it to the species level, although he was almost sure that it was yet undescribed. Unlike Balech's specimen, our cell has the posterior margin of LSL not rounded and has a longer RSL.

A new record of a Heteroschisma species for the State of Veracruz. Extremely rare in NPSAV. The only cell was found on 26 October 2006 at St. 3 (AVM).

IV. Genus Pseudophalacroma Jörg.

Pseudophalacroma nasutum (F. Stein) Jörg., 1923 (Pl. 3, Fig. 6-9; Pl. 11, Fig. 8). Bas.: Phalacroma nasutum F. Stein, 1883: pl. 18, fig. 1-6. Syn.: Prodinophysis nasuta (F. Stein) A. R. Loebl., 1965: 16; Dinophysis nasuta (F. Stein) Parke et Dixon, 1968: 797.

Cell almost regularly oval, broadly rounded anteriorly and more narrowly rounded posteriorly, without any antapical processes. Theca is coarsely areolated. Epitheca is rather high, about 0.2 of the hypotheca. A large pore is located near the suture between two epithecal plates, on left side, at about 0.25 of the length of the left epithecal plate measured along the suture. Cingulum is rather narrow, deeply excavated, with one row of pores. Cingular lists are laterally directed. LSL is short (about half the length of the hypotheca) and narrow, ear-shaped, supported by a 
curved R3, thickened at the base. RSL is barely visible in lateral view, trapezoidal, about 0.6 of the LSL length. Lb $50 \mu \mathrm{m}$, Db $45 \mu \mathrm{m}$, Dt $49 \mu \mathrm{m}$, W $32 \mu \mathrm{m} ; \mathrm{n}=1$.

Taxonomical note. A specimen from Veracruz shares the most of common features with Pseudophalacroma nasutum in Tai \& Skogsberg (1934): (1) one row of pores in the middle of the cingulum; (2) the apical pore rather far from the cingulum; (3) short, fairly narrow LSL rounded posteriorly, without marked ribs R1 and R2; (4) shape and length of RSL; and (5) coarsely areolated theca. Stein (1883) illustrated his specimen with more than one row of cingular pores and a widely rounded hypotheca. Tai \& Skogsberg (1934) gave a detailed description of both the genus Pseudophalacroma and the species $P$. nasutum, and our specimen corresponds rather well to the cells pictured in their work. However, our cell has the maximum depth just below the cingulum, while in Tai \& Skogsberg it is located in the middle part of the hypotheca. Abe (1967b: 104) considers that the species illustrated under the name of Pseudophalacroma nasutum cannot be assigned to the genus Pseudophalacroma and that most likely it is Metaphalacroma. The specimen from Veracruz is also similar to the type species Heteroschisma inaequale Kof. et Skogsb.; however, I cannot assign it either to the genus Heteroschisma Kof. et Skogsb. or to the genus Metaphalacroma Tai et Skogsb. because it has only one row of cingular pores (in both aforementioned genera there are two rows, judging from H. inaequale in Kofoid \& Skogsberg (1928: pl. 1, fig. 7, 8) and Tai \& Skogsberg (1934: 457, fig. 11).

A new record for the Gulf of Mexico, for which it has not yet been reported (see Steidinger et al., 2009: 149-152). The only cell was found on 19 September 2007 at St. 2 (CEP-II).

References: Tai \& Skogsberg, 1934*: 469, fig. 13A-K.

\section{Genus Histioneis Stein}

Key for identification of Histioneis species

1a Cells longer than they are wide, hypotheca is symmetrical in relation to the longitudinal axis of the cell 2

$1 \mathrm{~b}$ Cells wider than they are long, kidney- or bean-shaped hypotheca is asymmetrical in relation to the longitudinal axis of the cell

2a Epitheca is located in the middle in lateral view (1) Histioneis paraformis

$2 \mathrm{~b}$ Epitheca is displaced to the ventral side of the cell 3 
Okolodkov: Dinophysiales of the National Park Sistema Arrecifal Veracruzano
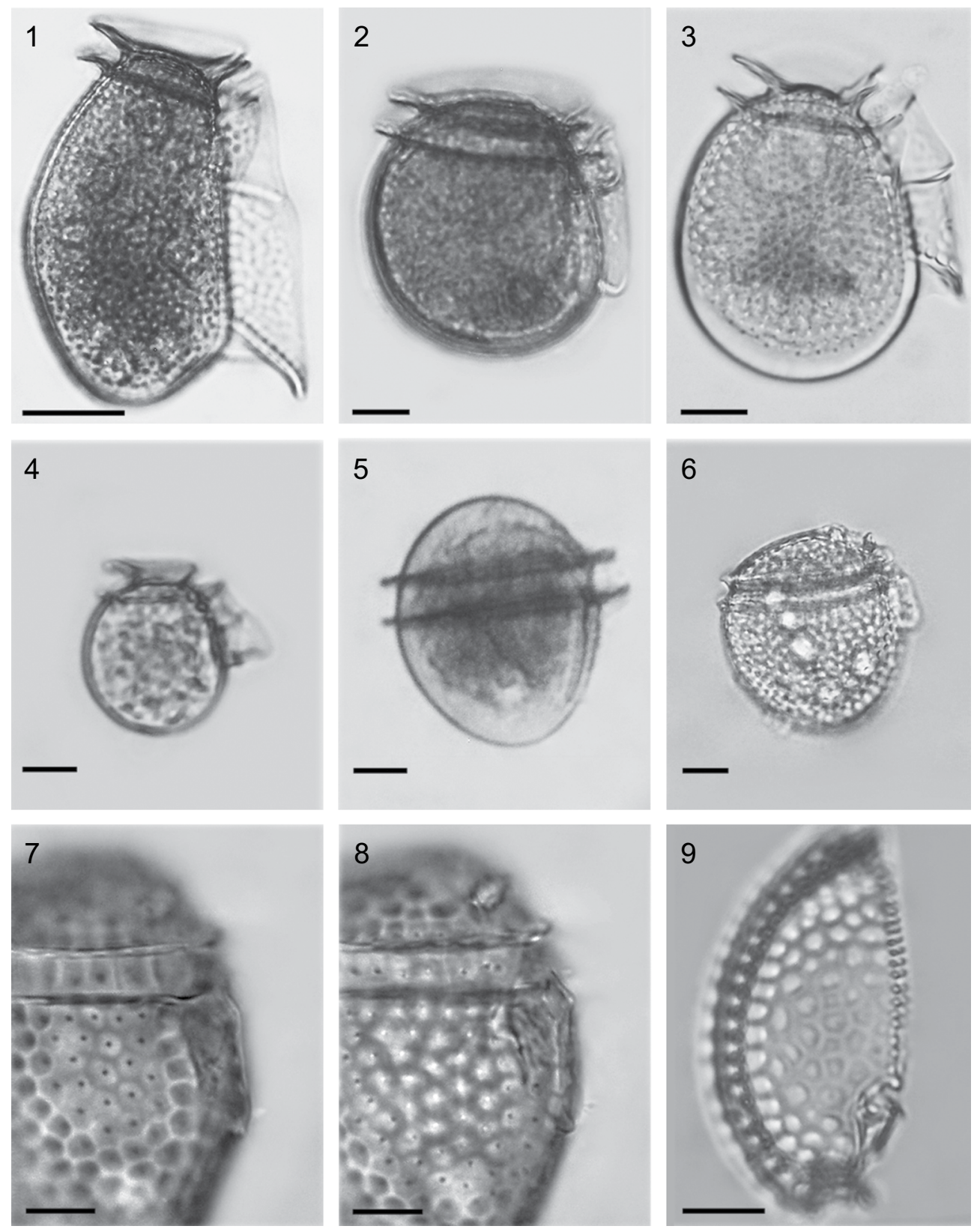

Plate 3. Fig. 1. Dinophysis schroederi. Fig. 2. Dinophysis cf. similis. Fig. 3. Dinophysis ovum. Fig. 4. Dinophysis cf. exigua. Fig. 5. Heteroschisma sp. Fig. 6-9. Pseudophalacroma nasutum ( 7 and 8 - a fragment of the cell with the left and right sulcal lists; 9 - left epithecal plate from inside). Scale bar: $10 \mu \mathrm{m}$. 
3a Hypotheca with large poroids, ACL is relatively narrow (about $1 / 3$ of the cell body length) (2) Histioneis crateriformis

3 b Hypotheca with small poroids, ACL is relatively wide (about $1 / 2$ of the cell body length) (3) Histioneis karstenii 4a Cells about twice as wide as they are long, with a strongly curved and long R2 fused with R3 forming a loop (4) Histioneis longicollis $4 \mathrm{~b}$ Cells slightly wider than they are long, with separated R2 and R3

(5) Histioneis isseli

1. Histioneis paraformis (Kof. et Skogsb.) Balech, 1971 (P1. 4, Fig. 1; P1. 11, Fig. 9). Bas.: Parahistioneis paraformis Kof. et Skogsb., 1928: 598, fig. 93(4), pl. 19, fig. 3, 6. Syn.: Histioneis para G. Murray et Whitting, 1899, partim: 333, fig. 4c (non fig. 4a, b); Parahistioneis acuta Böhm, 1931 in J. Schill., 1933: 216, fig. 206; Histioneis acuta in Balech, 1971 (Publ. Serv. Hidrogr. Naval B. Aires H 654): pl. 3, fig. 50 .

Cell bodies are suboval, symmetrical in relation to their longitudinal and latitudinal axes, with narrowly rounded antapex. The epitheca is small, centrally positioned. ACL is relatively wide, funnel-shaped. PCL is moderately wide, about 0.5 of the cell body depth, supported with vertical divergent ribs directed anteriorly-laterally. LSL is moderately developed, finely reticulate. R3 is about 1.5 times shorter than the cell body length, emerging ventrally-posteriorly. Lb $27-32.5 \mu \mathrm{m}(29.3 \pm 2.5$ $\mu \mathrm{m})$, Lt 55-67.5 $\mu \mathrm{m}(62.5 \pm 6.1 \mu \mathrm{m})$, Db 24-30 $\mu \mathrm{m}(26.9 \pm 2.8 \mu \mathrm{m})$, Dt 29-42.5 $\mu \mathrm{m}$ $(37.3 \pm 5.9 \mu \mathrm{m}) ; \mathrm{n}=4$.

Affinities. Our specimen corresponds more to Histioneis acuta in Balech (1971b: pl. 3, fig. 50), which is considered here, following Balech, a synonym to $H$. paraformis. A new combination, Histioneis acuta, appearing in Balech, 1971b (p. 15: as H. acuta; in figure legend to pl. 3, fig. 50 as $H$. acuta?) is invalid because no reference to the basionym was given. Histioneis paraformis is morphologically similar to H. para (see Murray \& Whitting, 1899*: pl. 32, fig. 4; Schiller, 1933*: 215, fig. 205a, b; Balech, 1962*: 137, pl. 17, fig. 254; 1988*: 65, pl. 15, fig. 4; Taylor, 1976****: 53, pl. 9, fig. 87, 88, pl. 41, fig. 490; Hernández-Becerril, 1988a**: 193, pl. 5, fig. 31, 32; Hernández-Becerril et al., 2008**: 7, fig. 65; Esqueda-Lara \& Hernández-Becerril, 2010**: 159, fig. 150a-c). However, the latter is different in having (1) a narrower rounded posterior end of the cell body, (2) a posterior rib (R3) emerging from the antapex, (3) the absence of ribs other than R3, and (4) a strongly reticulated LSL. 
A new record for the State of Veracruz. Extremely rare in NPSAV; the species was found only on 26 October 2005 at St. 3 (AVM).

References: Murray \& Whitting, 1899*: 333, pl. 32, fig. 4c; Yamaji, 1966*: 71, pl. 32, fig. 19; Balech, 1971b*: 14, pl. 3, fig. 47-49.

2. Histioneis crateriformis F. Stein, 1883 (Pl. 4, Fig. 2; Pl. 11, Fig. 10). Syn.: Parahistioneis crateriformis F. Stein, 1883: pl. 22, fig. 5, 6; P. acutiformis Rampi, 1947: 5, fig. 4.

Cell bodies are kidney-shaped, with the hypotheca symmetrical or slightly asymmetrical in relation to its longitudinal axis. The epitheca is minute. The dorsal edge of the cingulum is markedly concave and it is about twice as large as the ventral edge. ACL is about 0.36 of the cell body length, widely tubular, funnelshaped. PCL is short, about $0.33-0.50$ of the cell-body length, slightly narrower than the maximum cell body depth, supported by somewhat curved vertical ribs. LSL is moderately developed, reticulate mostly in its anterior part (between R1 and R2). R3 is about $0.38-0.46$ of the cell body length, emerging ventrally-posteriorly. Lb 30-37.5 $\mu \mathrm{m}(34.7 \pm 4.1 \mu \mathrm{m})$, Lt 50-65 $\mu \mathrm{m}(58.7 \pm 7.8 \mu \mathrm{m}), \mathrm{Db} 32.5-35 \mu \mathrm{m}(33.8 \pm 1.3 \mu \mathrm{m}), \mathrm{Dt}$ $37.5-42 \mu \mathrm{m}(39.8 \pm 2.3 \mu \mathrm{m}) ; \mathrm{n}=3$.

Morphological note. All three examined cells demonstrated variation in the number of morphological characteristics, so that they can be ascribed either to $H$. crateriformis or $\mathrm{H}$. reticulata Kof. et Skogsb. In the original illustration of $\mathrm{H}$. $\mathrm{cra}$ teriformis by Stein (1883), the ACL is as long as about 0.60 of the cell-body length, which is the main distinguishing feature between Stein's specimens and our cells. On the other hand, in their original drawing Kofoid et Skogsberg (1928: pl. 19, fig. $7,10)$ describe $H$. reticulata with a relatively robust cell body, a shorter R3 $(0.25$ of the cell-body length) and finely reticulated LSL and PCL, which principally distinguishes this species from the the cells from Veracruz (a poorly visible reticulation was defined in three cells, but it did not occupy the whole LSL). Although I follow Balech's (1971b) opinion about the synonymy of $H$. acutiformis to H. crateriformis, one should consider that R3 in the former is much longer, and its position is different (more ventral), although the species was described on the basis of only one cell.

Records in the State of Veracruz: Zamudio-Resendiz, 1998. Extremely rare in NPSAV; the species was found only on 26 October 2005 at St. 3 (AVM).

References: Stein, 1883*: 25, pl. 22, fig. 5, 6; Balech, 1971b*: 15, pl. 3, fig. 4046; 1988*: 68, pl. 15, fig. 8; Hernández-Becerril et al., 2008**: 6, fig. 63; EsquedaLara \& Hernández-Becerril, 2010**: 157, fig. 151a, b. 
3. Histioneis karstenii Kof. et J. R. Michener, 1911 (Pl. 4, Fig. 3; Pl. 11, Fig. 11). Syn.: Parahistioneis karstenii (Kof. et J. R. Michener) Kof. et Skogsb., 1928: 603, fig. 93(2), pl. 19, fig. 2.

Cell bodies are suboval, slightly asymmetrical in relation to their longitudinal and latitudinal axes, with a larger dorsal half. The epitheca is minute, positioned slightly closer to the ventral side. ACL is about 0.5 of the cell body length, widely tubular, funnel-shaped. PCL is short, less than 0.5 of the cell body depth, and as wide as the cell body depth, supported by somewhat curved vertical and horizontal ribs; the vertical ribs are parallel to each other in general. LSL is moderately developed, somewhat reticulate. R3 is about half of the cell body length, emerging ventrallyposteriorly. Lb $25 \mu \mathrm{m}$, Lt $50 \mu \mathrm{m}$, Db $25 \mu \mathrm{m}$, Dt $31.5 \mu \mathrm{m} ; \mathrm{n}=1$.

Morphological note. Our specimen corresponds rather well with those in Kofoid \& Skogsberg (1928) and Rampi (1939, 1947). Unlike those authors, who pictured the cells with a list behind R3 clearly extended to the dorsal part of cell, the cell from Veracruz has a narrower list that does not reach the antapex. It is also somewhat similar to the cell of H. oxypteris J. Schill. illustrated by Schiller (1928: 82, pl. 3, fig. 6; non fig. 7, lapsus clavis); however, the latter has no R2 and lacks a list behind R3. On the contrary, our specimen looks very similar to the picture of the cell of H. oxypteris in Balech (1971b: 17, pl. 3, fig. 35-36).

A new record for the State of Veracruz. Extremely rare in NPSAV; the species was found only on 26 October 2005 at St. 3 (AVM).

References: Kofoid \& Skogsberg, 1928*: 603, fig. 93(2), pl. 19, fig. 2; Schiller, 1933*: 217, fig. 207 (after Kofoid \& Skogsberg, 1928); Rampi, 1939*: 460, fig. 4; 1947*: 5, fig. 2 .

4. Histioneis longicollis Kof., 1907 (P1. 4, Fig. 4; Pl. 11, Fig. 12).

Cell bodies are bean-shaped or kidney-shaped, concave anteriorly and convex posteriorly, asymmetrical in relation to their longitudinal and latitudinal axes, with a larger dorsal half. The epitheca is minute. The dorsal edge of the cingulum is slightly or moderately concave, and it is about 2-3 times larger than the ventral edge, which is almost straight or somewhat convex. ACL is about 1.5 larger than the cell body length, narrowly tubular, funnel-shaped, with the dorsal margin more extended than the ventral one. PCL is large, slightly narrower than the cell body depth, and it is as long as the cell body or even longer, supported by straight or sigmoid vertical (including 2 dorsal ribs) and horizontal ribs, forming a sort of 
subquadrangular chamber; horizontal ribs support PCL near its anterior margin. LSL is well developed, somewhat reticulate, posteriorly extending far beyond the cell body (up to 2.0-2.8 times its length), supported ventrally-posteriorly, along the inner side of LSL, mainly by 2 (or 3?) ribs that fuse, forming a suboval frame (window), continuing as the only rib directed backward. Lb 19-24.5 $\mu \mathrm{m}(20.8 \pm 1.6$ $\mu \mathrm{m})$, Lt 65-81 $\mu \mathrm{m}(69.5 \pm 4.9 \mu \mathrm{m})$, Db 24-32.5 $\mu \mathrm{m}(30.0 \pm 2.5 \mu \mathrm{m})$, Dt 35-41 $\mu \mathrm{m}$ $(37.7 \pm 1.6 \mu \mathrm{m}) ; \mathrm{n}=11$.

Affinities. Our cells show a morphology intermediate between that of $H$. hyalina Kof. et J. R. Michener (Kofoid \& Skogsberg, 1928*: 679, fig. 95(5), pl. 20, fig. 4) and H. longicollis (see Kofoid, 1907*: 204, pl. 16, fig. 100; Kofoid \& Skogsberg, 1928*: 677, fig. 95(7), pl. 20, fig. 5, pl. 21, fig. 5). I ascribe it to H. longicollis due to the longer cells and less anterior-posterior compression of the cell body. Furthermore, it is similar to H. joergensenii J. Schill.; however, the latter has a slightly lower PCL, a markedly longer LSL, and a less anteriorily-posteriorly compressed cell body (Schiller, 1928: 83, fig. 42). Additionally, some similarities occur between $H$. longicollis and $H$. cymbalaria F. Stein (=H. depressa J. Schill.), but the latter has a much more symmetrical and more anteriorily-posteriorly compressed, shoe-like cell body (see Stein, 1883*: 25, pl. 22, fig. 7-10; Schiller, 1928*: 84, fig. 43; 1933*: 237, 240, fig. 230, 236; Rampi, 1941*: 119, fig. 1; 1947*: 12, fig. 14; Wood, 1963*: 6, fig. 13; 1968*: 77, fig. 212; Balech, 1971a*: 81, fig. 18-19; 1971b*: 21, pl. 1, fig. 14-17, pl. 2, fig. 18; Taylor, 1976*: 44, pl. 10, fig. 94; EsquedaLara \& Hernández-Becerril, 2010**: 158, fig. 149a-c). Even more species have a loop formed by the fission rib (R2) and the posterior rib (R3): H. gubernans F. Schütt, H. pavillardii Rampi, H. detonii Rampi (Rampi, 1939: 460, 461; 1940: 28, fig. 48; 1947: 11, 13), H. pacifica Kof. et Skogsb. (Kofoid \& Skogsberg, 1928: 681, fig. 95(12), pl. 20, fig. 8; Balech, 1971b: 17, pl. 2, fig. 22, 25, 27, 28), H. mitchellana G. Murray et Whitting (Murray \& Whitting, 1899: 335, pl. 33, fig. 3), and H. voukii J. Schill. (Schiller, 1928: 82, fig. 41). The problem of as yet unknown infraspecific variation significantly hinders the correct identification at the species level; for example, many Histioneis (more than 50\% of known species) and Dinophysis species were described based on a single specimen (Balech, 1971b: 14; Hallegraeff \& Lucas, 1988: 25).

A new record for the State of Veracruz. Extremely rare in NPSAV; the species was found only on 26 October 2005 at St. 3 (AVM).

References: Kofoid et Skogsberg, 1928*: 679, fig. 95(5), pl. 20, fig. 4; Schiller, 1928*: 81, pl. 3, fig. 6; 1933*: 238, fig. 231a; Rampi, 1940*: 29, fig. 47; Balech, 1971b*: 19, pl. 2, fig. 26, 29, 31. 
5. Histioneis isseli Forti, 1932 (Pl. 4, Fig. 5; Pl. 7, Fig. 4; Pl. 11, Fig. 13).

Cell bodies are kidney- or bean-shaped, asymmetrical in relation to their longitudinal and latitudinal axes, with a larger dorsal half. The epitheca is minute. ACL is about as long as the cell body length, widely tubular, funnel-shaped. PCL is moderately developed, as wide as the cell body depth, and it is as long as the cell body, supported by slightly curved vertical and horizontal ribs. LSL is moderately developed, somewhat reticulate, markedly pitted before R2. R2 is small, curved, directed posteriorlylaterally. R3 is slightly longer than the cell body, almost straight or somewhat curved, emerging from the antapical end of the body. Lb 25-27.5 $\mu \mathrm{m}(26.7 \pm 1.4 \mu \mathrm{m}), \mathrm{Lt} 72.5-80$ $\mu \mathrm{m}(77.5 \pm 4.3 \mu \mathrm{m}), \mathrm{Db} 30-37.5 \mu \mathrm{m}(34.2 \pm 3.8 \mu \mathrm{m}), \mathrm{Dt} 35-45 \mu \mathrm{m}(40.0 \pm 5.0 \mu \mathrm{m}) ; \mathrm{n}=3$.

Affinities. Our specimens have some features in common with $H$. subcarinata Rampi (Rampi, 1940*: 30, fig. 46 (as H. carinata Kof.); 1947*: 13, fig. 8; Balech, 1971b*: 20, pl. 2, fig. 19, 20). Unlike the latter, they have (1) less curved R3, (2) R2 directed posteriorly-laterally, and (3) LSL of a different shape, especially in its posterior part. Histioneis isseli is also morphologically similar to H. carinata Kof. (Kofoid, 1907: 203, pl. 16, fig. 98); however, the latter has (1) a larger and wider, more anteriorly-posteriorly compressed cell body, dorsally diminishing in size, (2) a much more curved R3, and (3) a LSL of a different shape, especially in its posterior part.

A new record for the Gulf of Mexico. Extremely rare in NPSAV; the species was found only on 26 October 2005 at St. 3 (AVM).

References: Forti, 1932*: 539, fig. 1; Hernández-Becerril, 1988a**: 192, pl. 2, fig. 8 ; $1988 b^{* *}$ : pl. 1 , fig. 8 .

\section{Genus Ornithocercus F. Stein}

Key for identification of Ornithocercus species

1a Left sulcal list (LSL) reaches the antapex ……............................................... 2

$1 \mathrm{~b}$ LSL extends onto the dorsal side of the cell ..................................................... 3

2a Posterior-ventral part of LSL (= posterior sail) slightly convex and subequal to the cell body length (1) Ornithocercus cristatus

$2 \mathrm{~b}$ Posterior-ventral part of LSL concave and wider than the cell body length (2) Ornithocercus heteroporus

3a Posterior-ventral part of LSL is not divided into lobes

(3) Ornithocercus quadratus 
3b Posterior-ventral part of LSL is divided into lobes

4a Cell body relatively small (40-47 $\mu \mathrm{m}$ in length), posterior-ventral part of LSL three-lobed (4) Ornithocercus magnificus $4 \mathrm{~b}$ Cell body is relatively large (50-63 $\mu \mathrm{m}$ in length, sometimes less), posteriorventral part of LSL consisting of more than three lobes or unclearly lobed ...... 5 5a Posterior margin of LSL supported by 5 main ribs that alternate in length (longer and shorter ones)

(5) Ornithocercus thumii

5b Posterior margin of LSL supported by 3-5 main ribs of about equal length ....... 6 6a Posterior margin of LSL supported by 3 main ribs, being slightly three-lobed

(6) Ornithocercus skogsbergii

6b Posterior margin of LSL supported by 4 main ribs, being slightly four-lobed

(7) Ornithocercus steinii

1. Ornithocercus cristatus Matzen., 1933 (Pl. 4, Fig. 6; Pl. 12, Fig. 1).

Cell body is small, suboval, elongated, slightly asymmetrical. Cingulum is not excavated. LSL extends to the antapex, with a more or less direct ventral margin and a sigmoid posterior margin, forming almost a right angle; behind the sulcus the LSL is supported with one thick and a number of thin ribs. Lb 30-37 $\mu \mathrm{m}(33.2 \pm 3.5$ $\mu \mathrm{m})$, Lt 65-77 $\mu \mathrm{m}(71.3 \pm 6.0 \mu \mathrm{m})$, Db 27.5-32.5 $\mu \mathrm{m}(30 \pm 2.5 \mu \mathrm{m})$, Dt 32.5-54 $\mu \mathrm{m}$ $(45.5 \pm 11.4 \mu \mathrm{m}) ; \mathrm{n}=3$.

Morphological note. All three cells were found in the same sample together with $O$. heteroporus, so their belonging to the latter should not be excluded (in this case, it may be a young cell, sometimes called schizont; see Norris, 1969). However, the examined cells are in accordance with the original line drawing by Matzenauer (1933) by (1) their elongated, almost symmetrical cell body (although our cells have a narrower rounded antapex), (2) the posterior margin of LSL parallel to the sulcus, (3) the absence of 2 or 3 thick main radial ribs, and (4) the cingulum not excavated. In Matzenauer's figure, LSL has a continuously convex margin.

A new record for the State of Veracruz. Extremely rare in NPSAV; the species was found only on 26 October 2005 at St. 3 (AVM).

References: Matzenauer, 1933*: 447, fig. 11; Balech, 1967a*: 93, pl. 2, fig. 3846; Hernández-Becerril et al., 2008**: 9, fig. 33.

2. Ornithocercus heteroporus Kof., 1907 (P1. 4, Fig. 7 and 8; P1. 12, Fig. 2). Syn.: Ornithocercus biclavatus Wood, 1954: 211, fig. 66. 
Cell bodies are small, oval, slightly elongated obliquely along the longitudinal axis (from its posterior dorsal end to anterior ventral end). Cingulum is slightly or not excavated. LSL extends to the antapex, with more or less direct or slightly convex ventral margin and concave posterior-ventral margin; behind the sulcus it is supported by two thick main ribs as long as the cell depth, divergent in their proximal parts and parallel or slightly convergent in their distal parts, and 4-5 additional thinner ribs. Lb 32.5-35 $\mu \mathrm{m}(33.8 \pm 1.1 \mu \mathrm{m}), \mathrm{Lt} 65-80 \mu \mathrm{m}$ (72.9 $\pm 6.2 \mu \mathrm{m}), \mathrm{Db} 30-36.5$ $\mu \mathrm{m}(32.6 \pm 3.6 \mu \mathrm{m})$, Dt $45-55 \mu \mathrm{m}(49.7 \pm 3.4 \mu \mathrm{m}) ; \mathrm{n}=5$.

Records in the State of Veracruz: Okolodkov et al., 2011. Extremely rare in NPSAV; the species was found only on 26 October 2005 at St. 3 (AVM).

References: Kofoid, 1907*: 206, pl. 12, fig. 70; Kofoid \& Skogsberg, 1928*: 517, fig. 75, 76, pl. 18, fig. 1, 3; Schiller, 1933*: 195, fig. 187a-d (after Kofoid \& Skogsberg, 1928); Rampi, 1940*: 25, fig. 53; Yamaji, 1966*: 72, pl. 33, fig. 9; Abé, 1967b*: 81, fig. 28a, b; Taylor, 1976*: 48, pl. 8, fig. 83; Balech, 1988*: 59, pl. 14, fig. 4; Delgado \& Fortuño, 1991****: fig. 4M, pl. 32, fig. c; Licea et al., 1995*: 23, pl. 21, fig. 11; Steidinger \& Tangen, 1996*: 436, pl. 13; Hernández-Rosas et al., 2007**: 266, fig. 3c, 4(b1-b5); Hernández-Becerril et al., 2008**: 9, fig. 32; Esqueda-Lara \& Hernández-Becerril, 2010**: 162, fig. 155a-c.

3. Ornithocercus quadratus F. Schütt, 1900 (Pl. 4, Fig. 9; Pl. 12, Fig. 3). Syn.: Histioneis quadrata Lemmerm., 1901: 376; Ornithocercus similis Jörg., 1923: 37, fig. 51.

Cells bodies are large, suboval, slightly deeper than long, with the epitheca markedly displaced to the ventral side. Cingulum is dorsally excavated and distinctly wider than ventrally. LSL extends to one-third (posterior-dorsal) of the dorsal side of the cell, forming a more or less rectangular outline behind the cell body. Behind the sulcus it is supported by 8-9 main ribs directed posteriorly-laterally or posteriorly. Both ventral and dorsal margins of LSL are slightly convex, and the posterior margin is undulating, almost straight. Three posterior ribs $(\mathrm{B}, \mathrm{C}$ and $\mathrm{D}$; for rib designation, see Schütt, 1900: 254, Fig. 1-10) are of equal or subequal length, located closer to each other. RSL is rather broad, extending almost to the antapex, terminating near the group of three posterior ribs. Small ribs originating from the surrounding rib are common along the margin of LSL from the sulcus to the dorsal side. Some cells with exosymbiotic cyanobacteria were observed. Lb 55-66.5 $\mu \mathrm{m}$ (59.5 $\pm 3.2 \mu \mathrm{m})$, Lt 122-142.5 $\mu \mathrm{m}(130.5 \pm 11.8 \mu \mathrm{m}), \mathrm{Db} 63-72.5 \mu \mathrm{m}(70.3 \pm 5.0 \mu \mathrm{m}), \mathrm{Dt}$ 91-117.5 $\mu \mathrm{m}(107.6 \pm 13.2 \mu \mathrm{m}) ; \mathrm{n}=10$. 

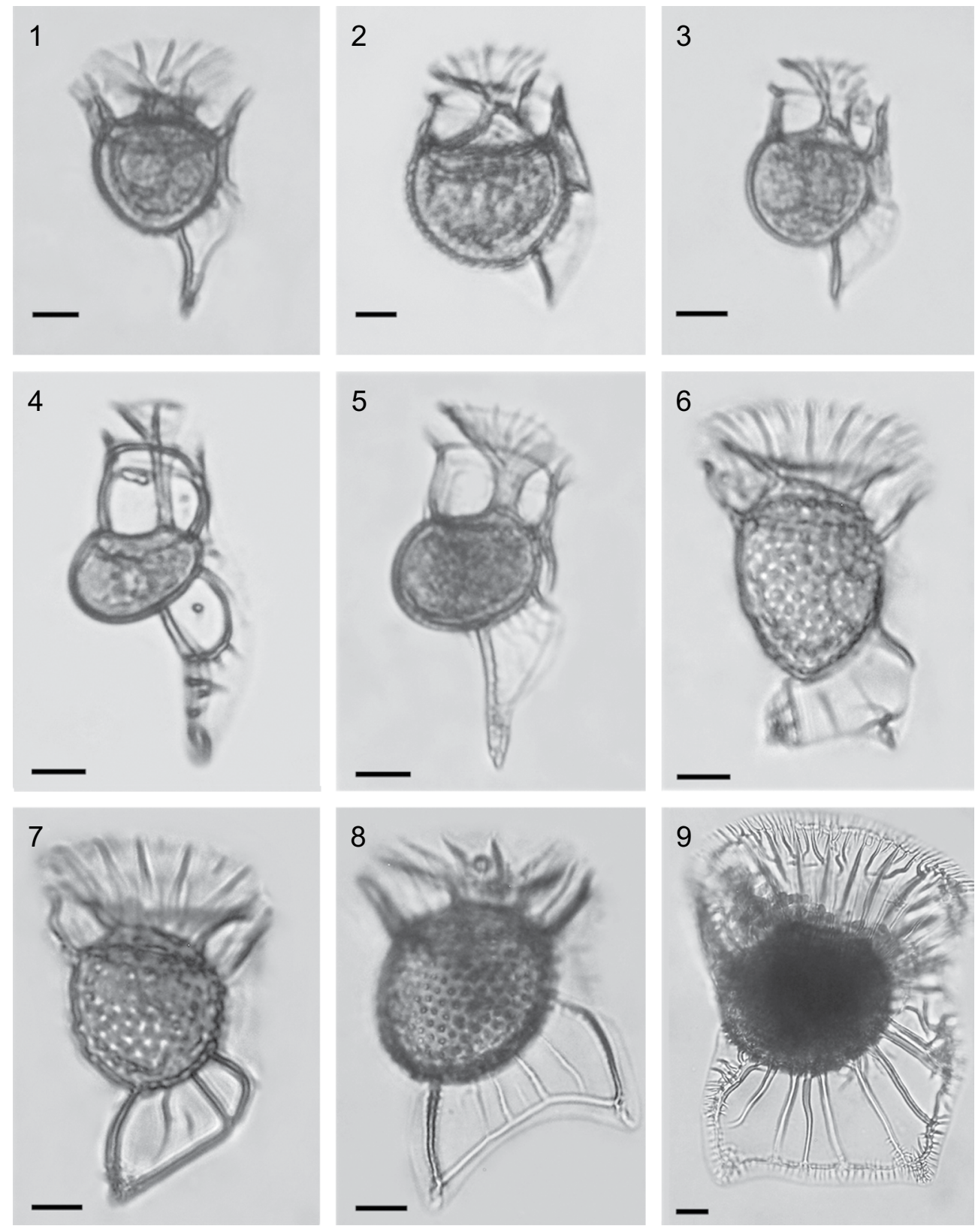

Plate 4. Fig. 1. Histioneis paraformis. Fig. 2. Histioneis crateriformis. Fig. 3. Histioneis karstenii. Fig. 4. Histioneis longicollis. Fig. 5. Histioneis isseli. Fig. 6. Ornithocercus cristatus. Fig. 7 and 8. Ornithocercus heteroporus ( 7 - presumably a young cell). Fig. 9. Ornithocercus quadratus. Scale bar: $10 \mu \mathrm{m}$. 
Morphological note. Our cells correspond to the observation by Abé (1967b: 89) who described rib C as "lying somewhat slantwise as its basal end is deflected toward the right" and who was the first to illustrate this peculiarity, although it is not thinner than the neighboring ribs $\mathrm{B}$ and $\mathrm{D}$.

Records in the State of Veracruz: Zamudio-Resendiz, 1998; Aquino-Cruz, 2002*** (misidentification; referred to as $O$. steinii); Okolodkov et al., 2011. Very rare in NPSAV; the species was observed only on 13 October 2006 at St. 9 (CEP-I) and on 26 October 2006 at St. 3 (AVM).

References: Schütt, 1900*: 5, fig. 1-4, 12, 13; Kofoid \& Skogsberg, 1928*: 561, fig. 85(5), 86-88, pl. 17, fig. 2, 8; Schiller, 1933*: 204, fig. 194a-f, 195a-d (after Kofoid \& Skogsberg, 1928); Rampi, 1939: 459, fig. 11; 1940*: 25, fig. 55; Abé, 1967b*: 89, fig. 33a, b; Norris, 1969*: fig. 20; Taylor, 1976****: 50, pl. 8, fig. 77-82, pl. 42, fig. 499-501; Pesantes-Santana, 1978*: 25, pl. 16, fig. 11; Dodge, 1985***: 29; Balech, 1988*: 60, pl. 14, fig. 10; Steidinger \& Tangen, 1996*: 436, pl. 13; Hernández-Rosas et al., 2007*****: 267, fig. 2a-f, 3f (mistakenly, in the legend to fig. 3 it is referred to fig. 3e), 4(d1-d5), 11d; Esqueda-Lara \& HernándezBecerril, 2010**: 165, fig. 158a-c (var. assimilis (Jörg.) Taylor), 166, fig. 159 (var. simplex Kof. et Skogsb.).

4. Ornithocercus magnificus F. Stein, 1883 (Pl. 5, Fig. 1-3; Pl. 8, Fig. 1 and 2; Pl. 12, Fig. 4).

Cell bodies are relatively small, subcircular in lateral view, slightly asymmetrical in relation to the longitudinal axis, directed from the posterior dorsal end to anterior ventral end. Cingulum is slightly excavated. LSL extends to one-third (posterior-dorsal) of the dorsal side of the cell. Behind the sulcus it is supported by 5 main ribs directed posteriorly, of which 3 ribs (B, C and D) positioned antapically are located closer to each other, and the central rib of these three is situated out of the plane of the other two (which is clearly seen in ventral or dorsal view; Pl. 7, Fig. 5 and 6). The posterior margin of LSL is clearly three-lobed, forming two concavities asymmetrically located on both sides of the group of three posterior main ribs, the central rib being the longest. Sometimes the main ribs form anastomoses between them; the main ribs also do the same where they connect with the posterior marginal rib, forming nodes. RSL is narrow, terminating behind the main rib located closer to the sulcus. Some cells with exosymbiotic cyanobacteria were observed. Lb 40-47 $\mu \mathrm{m}(43.4 \pm 2.1 \mu \mathrm{m})$, Lt 92.5-115 $\mu \mathrm{m}(105.7 \pm 7.1 \mu \mathrm{m}), \mathrm{Db} 41-46.5 \mu \mathrm{m}(43.3 \pm 1.4 \mu \mathrm{m}), \mathrm{Dt}$ $75-93 \mu \mathrm{m}(83.4 \pm 5.0 \mu \mathrm{m}) ; \mathrm{n}=29$. 
Records in the State of Veracruz: Avendaño-Sánchez \& Sotomayor-Navarro, 1982; Zamudio-Resendiz, 1998; Okolodkov et al., 2011. The most common species in the genus Ornithocercus in the study area (Jan., Aug., Oct. Nov., Dec.).

References: Stein, 1883*, pro parte: pl. 23, fig. 1, 2 (non fig. 3-6); Schütt, 1895*: pl. 5, fig. 21; 1899*: 690, fig. 12; 1900*: 262, fig. 8-10; Kofoid \& Skogsberg, 1928*: 529, fig. 79, 80, pl. 16, fig. 3; Schiller, 1933*: 198, fig. 190a, b (after Kofoid \& Skogsberg, 1928); Rampi, 1940*: 25, fig. 54; Silva, 1955*: 131, pl. 3, fig. 5; Yamaji, 1966*: 72, pl. 33, fig. 5; Abé, 1967b*: 88, fig. 32a-d; Norris, 1969*: 178, fig. 2-15, 17(?); Steidinger \& Williams, 1970**: pl. 25, fig. 79; Taylor, 1976****: 49, pl. 7, fig. 67-69, pl. 42, fig. 505a, b; Pesantes-Santana, 1978*: 25, pl. 16, fig. 12; Tester \& Steidinger, 1979**: 30, fig. 75; Dodge, 1985***: 28; Balech, 1988*: 61, pl. 14, fig. 7, 8; Hernández-Becerril, 1988a**: 193, pl. 2, fig. 9, 10; Delgado \& Fortuño, 1991****: 5, fig. 4L, pl. 32, fig. d; Licea et al., 1995****: 23, pl. 8, fig. 3, pl. 21, fig. 12; Steidinger \& Tangen, 1996*: 436, pl. 13; Hernández-Rosas et al., 2007*****: 266, fig. 3d, 4(c1-c5), 11a, b; Alonso-Rodríguez et al., 2008**: 138; Hernández-Becerril et al., 2008**: 9, fig. 28; Al-Kandari et al., 2009**: 153, pl. 5, fig. C (p. 302); Esqueda-Lara \& Hernández-Becerril, 2010**: 163, fig. 156a-c.

5. Ornithocercus thumii (Schmidt) Kof. et Skogsb., 1928 (Pl. 5, Fig. 4; Pl. 12, Fig. 5). Bas.: Parelion thumii Schmidt, 1888: pl. 144(59-61).

Cells bodies are large, suboval, slightly deeper than long, with the epitheca markedly displaced to the ventral side. The cingulum is dorsally excavated and distinctly wider than ventrally. LSL extends to one-half of the dorsal side of the cell. Six main ribs behind the sulcus are spaced almost equally. The posterior margin of LSL is supported by 5 main ribs and forms two concavities between them; in the center of each of them the shorter ribs B and D are located. RSL is narrow, expanding continuously posteriorly, terminating about half-way from the sulcus to the antapex. Some cells with exosymbiotic cyanobacteria were observed. Lb 50-60 $\mu \mathrm{m}(56.2 \pm 2.8$ $\mu \mathrm{m})$, Lt 112.5-140 $\mu \mathrm{m}(127.0 \pm 9.5 \mu \mathrm{m})$, Db 60-67.5 $\mu \mathrm{m}(62.5 \pm 1.9 \mu \mathrm{m})$, Dt 92.5-120 $\mu \mathrm{m}(101.9 \pm 7.7 \mu \mathrm{m}) ; \mathrm{n}=24$.

Records in the State of Veracruz: Zamudio-Resendiz, 1998; Okolodkov et al., 2011. Rare in NPSAV; the species was found only on 26 October 2005 at St. 3 (AVM).

References: Stein, 1883*: pl. 23, fig. 4, 5 (misidentification, reported as $O$. magnificus; non fig. 1-3, 6); Schütt, 1900*: fig. 7 (misidentification, reported as $O$. Steinii); Kofoid \& Skogsberg, 1928*: 540 (mistakenly spelled as O. thurni), fig. 81, 
82, pl. 18(4-6); Schiller, 1933*: 201 (mistakenly spelled as $O$. Thurnii), fig. 191a-h (after Murray \& Whitting, 1899; Kofoid \& Skogsberg, 1928); Yamaji, 1966*: 72, pl. 33, fig. 6 (misidentification, reported as O. steinii); Abé, 1967b*: 90, fig. 34a-i (mistakenly spelled as $O$. thurnii); Wood, 1968*: 87, fig. 244 (misidentification; reported as O. steini), fig. 245; Norris, 1969*: fig. 23 (mistakenly spelled as O. thurni); Steidinger \& Williams, 1970**: pl. 25, fig. 81; Taylor, 1976*: 53, pl. 7, fig. 71, 72, 74; Steidinger \& Tangen, 1996*: 437, pl. 13; Hernández-Rosas et al., 2007*****: 269 (mistakenly, O. magnificus is indicated as a synonym to O. thumii), fig. 3i, 4(f1f5), 10a, 11f; Hernández-Becerril et al., 2008*****: fig. 36, 37 (misidentification; referred to as O. steinii); Esqueda-Lara \& Hernández-Becerril, 2010**: 168, fig. 161a-c (misidentification; referred to as O. steinii), 169, fig. 162.

\section{Ornithocercus skogsbergii T. H. Abé, 1967 (P1. 5, Fig. 5; P1. 12, Fig. 6).}

Cells bodies are relatively small, suboval, slightly deeper than long, with the epitheca markedly displaced to the ventral side. The cingulum is dorsally excavated and distinctly wider than ventrally. LSL extends to one-half of the dorsal side of the cell. Five thick main ribs behind the sulcus are spaced almost equally. The posterior margin of LSL is supported by 3 main ribs and forms two concavities between them. RSL is narrow, expanding continuously posteriorly, terminating rather far from the antapex. One cell with exosymbiotic Synechococcus was observed. Lb $47 \mu \mathrm{m}$, Lt $100 \mu \mathrm{m}, \mathrm{Db} 50 \mu \mathrm{m}$, Dt $80 \mu \mathrm{m} ; \mathrm{n}=1$.

A new record for the State of Veracruz. Extremely rare in NPSAV; the species was found only on 10 May 2005 at St. 4 (AVM).

References: Abé, 1967b*: 85, fig. 31a-k; Taylor, 1976*: 51, pl. 7, fig. 70.

7. Ornithocercus steinii F. Schütt, 1900 (Pl. 5, Fig. 6; Pl. 8, Fig. 3 and 4; Pl. 12, Fig. 7). Syn.: Ornithocercus serratus Kof., 1907 (Bull. Mus. Compar. Zool. Harvard Coll. 50, 6): 206, pl. 15, fig. 93.

Cells bodies are large, suboval, slightly deeper than long, with the epitheca markedly displaced to the ventral side. The cingulum is dorsally excavated and distinctly wider than ventrally. LSL extends to nearly one-half of the dorsal side of the cell. Six main ribs behind the sulcus are spaced almost equally. The posterior margin of LSL is supported by 4 main ribs and forms three concavities between them. RSL is narrow, expanding continuously posteriorly, terminating about half-way from the sulcus to the antapex. Some cells with exosymbiotic cyanobacteria were observed. 
Lb 52-62.5 $\mu \mathrm{m}(58.8 \pm 2.4 \mu \mathrm{m})$, Lt 134-162.5 $\mu \mathrm{m}(141.3 \pm 10.2 \mu \mathrm{m})$, Db 62.5-72.5 $\mu \mathrm{m}$ (68.0 $2.6 \mu \mathrm{m})$, Dt 90-125 $\mu \mathrm{m}(113.6 \pm 6.7 \mu \mathrm{m}) ; \mathrm{n}=35$.

Records in the State of Veracruz: Avendaño-Sánchez \& Sotomayor-Navarro, 1982 (as O. serratus); Okolodkov et al., 2011. Rare in NPSAV (March, May, Oct.).

References: Schütt, 1900*, pro parte: fig. 5, 6 (non fig. 7); Silva, 1955*: 131, pl. 3, fig. 6 (?); Yamaji, 1966*: 72, pl. 33, fig. 7 (as O. serratus); Halim, 1967**: 731, pl. 5, fig. 65; Norris, 1969*: fig. 22; Steidinger \& Williams, 1970**: pl. 25, fig. 80; Taylor, 1976*: 52, pl. 7, fig. 72, 73; Pesantes-Santana, 1978*: 25, pl. 17, fig. 1-3 (mistakenly spelled as O. Steinü); Balech, 1988*: 61, pl. 15, fig. 1; Delgado \& Fortuño, 1991*: 5, fig. 4O; Licea et al., 1995***: 24, pl. 21, fig. 13; Steidinger \& Tangen, 1996*: 437, pl. 13; Hernández-Rosas et al., 2007*****: 267, fig. 3h (mistakenly, in the legend to fig. 3 it is referred to fig. $3 \mathrm{f}), 4(\mathrm{el}-\mathrm{e} 5), 10 \mathrm{~b}, 11 \mathrm{e}$.

\section{Genus Phalacroma F. Stein}

Key for identification of Phalacroma species

1a Cells with a posterior spine (1) Phalacroma doryphorum

$1 \mathrm{~b}$ Cells without a posterior spine 2

2a Cells are usually large, $80-105 \mu \mathrm{m}$ long, theca strongly reticulate. 3

$2 \mathrm{~b}$ Cells are usually medium-sized or small, rarely large (up to $100 \mu \mathrm{m}$ long), theca smooth or strongly areolated

3a Cells are cuneate, with a low and very broad epitheca ...... (2) Phalacroma cuneus $3 \mathrm{~b}$ Cells are oval or suboval, with a high epitheca

4a Epitheca is narrowly rounded; its sides form an angle of about $90 \%$ in lateral view

(3) Phalacroma apicatum

$4 \mathrm{~b}$ Epitheca is broadly rounded; its sides form an angle of $100-110 \%$ in lateral view

(4) Phalacroma argus

5a Cells are inverted fig-shaped, with a drawn-out posteriorly projecting lobe (5) Phalacroma hindmarchii

$5 \mathrm{~b}$ Cells are not fig-shaped 6

6a Cells with concave posterior-ventral margin in lateral view, theca strongly areolated 7

$6 \mathrm{~b}$ Cells are broadly rounded posteriorly 8

7a Cells are medium-sized, $65-80 \mu \mathrm{m}$ long, with a drawn-out posterior part and strongly concave posterior-ventral margin

(6) Phalacroma rapa 
$7 \mathrm{~b}$ Cells are small, 45-50 $\mu \mathrm{m}$ long, with a conical posterior part and slightly concave posterior-ventral margin (7) Phalacroma mitra 8a R2 is closer to R3 than to R1 (8) Phalacroma equalanti $8 \mathrm{~b} \mathrm{R} 2$ is closer to $\mathrm{R} 1$ than to $\mathrm{R} 3$ (9) Phalacroma rotundatum

1. Phalacroma doryphorum F. Stein, 1883 (Pl. 5, Fig. 7; Pl. 12, Fig. 8). Syn.: Phalacroma doryphoroides P. A. Dang., 1927 (Ann. l'Inst. Océanogr. Nouv. Sér. 4, 8): 380, fig. 44b, c; Dinophysis doryphora (F. Stein) T. H. Abé, 1967 (Publ. Seto Mar. Biol. Lab. 15, 1): 77, fig. 26.

Cells are subovate, egg-shaped, sometimes almost triangular, with a broadly rounded epitheca and narrowly tapered hypotheca terminating with a strong triangular spine, somewhat deflected ventrally. The cell is widest at the level of R2 or somewhat behind it. The epitheca is short, slightly convex. The hypotheca is slightly asymmetrical in relation to the longitudinal axis of the cell; its posterior part is more rounded dorsally and almost straight ventrally. The cingulum is slightly convex. The cingular lists are narrow, directed laterally-anteriorly. LSL is wide, can be finely reticulate as also the antapical spine. The distance between R2 and R3 is aproximately 1.5 greater than between R1 and R2. R3 is the longest and the thickest, straight or slightly curved, directed laterally-posteriorly, about 2.0-2.5 times longer than R2, reaching the anterior two-thirds of the length of the cell body. RSL terminates just behind R3. Lb

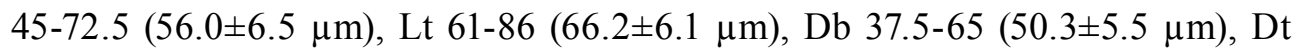
47.5-80 (62.6 $\pm 6.4 \mu \mathrm{m}) ; \mathrm{n}=16$.

Records in the State of Veracruz: Avendaño-Sánchez \& Sotomayor-Navarro, 1982; Okolodkov et al., 2011. Rare in NPSAV; the species was found only on 26 October 2005 at St. 3 (AVM).

References: Stein, 1883*: 23, pl. 19, fig. 1-4; Schütt, 1895*: 56, pl. 4, fig. 19; 1899*: 42, pl. 6, fig. 17; Kofoid \& Skogsberg, 1928*: 175, fig. 23(1-5), 24; Schiller, 1933*: 99, fig. 91a, b (after Kofoid \& Skogsberg, 1928); Rampi, 1940*: 17, fig. 27; Yamaji, 1966*: 68, pl. 31, fig. 20; Abé, 1967a*: 77, fig. 26; Norris \& Berner Jr., 1970*: 161, fig. 23-45; Taylor, 1976*: 35, pl. 4, fig. 41, 42; Pesantes-Santana, 1978*: 28, pl. 18, fig. 1; Hallegraeff \& Lucas, 1988***: fig. 8; Delgado \& Fortuño, 1991* ***: 4, fig. 4F, pl. 36, fig. d (as D. doriphora); Licea et al., 1995****: 19, pl. 6, fig. 5, pl. 20, fig. 12; Steidinger \& Tangen, 1996*: 439, pl. 17; Hansen et al., 2001**: 28, pl. 2, fig. B (as D. doryphorum); Hernández-Becerril et al., 2008**: 3, fig. 11; EsquedaLara \& Hernández-Becerril, 2010**: 147, fig. 140. 
2. Phalacroma cuneus F. Schütt, 1895 (P1. 5, Fig. 8; Pl. 12, Fig. 9). Syn.: Phalacroma blackmanii G. Murray et Whitting, 1899: 330, pl. 31, fig. 4a, b; Dinophysis cuneus (Schütt) T. H. Abé, 1967 (Publ. Seto Mar. Biol. Lab. 15, 1): 68, fig. 21a-h.

Cells are large, cuneate, with low, broadly rounded epitheca, much narrower rounded posterior portion of the hypotheca, and nearly straight or slightly convex (sometimes slightly concave) sides of the hypotheca, with coarsely reticulate theca. LSL is of moderate length and narrow, with three short supporting ribs of subequal size. The distance between R2 and R3 is aproximately twice that between R1 and $\mathrm{R} 2 . \mathrm{RSL}$ is very narrow, barely visible. Lb $92.5-97.5 \mu \mathrm{m}(95.0 \pm 3.5 \mu \mathrm{m}), \mathrm{Db}$ 97-100 $\mu \mathrm{m}(98.5 \pm 2.1 \mu \mathrm{m}), \mathrm{Dt} 107-110 \mu \mathrm{m}(108.5 \pm 2.1 \mu \mathrm{m}) ; \mathrm{n}=2$.

Morphological note. The cell outline and the measurements strongly depend on the tilting of the specimens under examination due to the cuneate shape of the cell in dorsal/ventral view. The species is morphologically similar to $P$. giganteum Kof. et J. R. Michener known from the eastern tropical Pacific, the length of which is $148 \mu \mathrm{m}$ (Kofoid \& Skogsberg, 1928: 136, pl. 2, fig. 2, 4, pl. 3, fig. 2, fig. 14(1).

Records in the State of Veracruz: Avendaño-Sánchez \& Sotomayor-Navarro, 1982 (misspelled: P. cuncus); Zamudio-Resendiz, 1998. Extremely rare in NPSAV; the species was found only on 26 October 2005 at St. 3 (AVM).

References: Schütt, 1895*: 148, pl. 3, fig. 14; 1896*: 27, fig. 38B; Kofoid \& Skogsberg, 1928*: 124, fig. 12, 13; Schiller, 1933*: 89, fig. 76a-d (after Murray \& Whitting, 1899; Kofoid \& Skogsberg, 1928); Rampi, 1940*: 16, fig. 22; Balech, 1962*: 129, pl. 17, fig. 238-242, 247 (some thecal plates); Yamaji, 1966*: 67, pl. 31, fig. 16; Halim, 1967**: 749, pl. 7, fig. 92, 93; Taylor, 1976*: 35, pl. 5, fig. 46, 47; Dodge, 1985***: 19; Hallegraeff \& Lucas, 1988***: fig. 18, 23b; Delgado \& Fortuño, 1991***: 4, pl. 37, fig. c, d; Steidinger \& Tangen, 1996*: 439, pl. 14; Hernández-Becerril et al., 2008**: 3, fig. 8; Esqueda-Lara \& Hernández-Becerril, 2010**: 146, fig. 139a-d.

3. Phalacroma apicatum Kof. et Skogsb., 1928 (Pl. 5, Fig. 9; Pl. 13, Fig. 1). Syn.: Dinophysis apicata (Kof. et Skogsb.) T. H. Abé, 1967 (Publ. Seto Mar. Biol. Lab. $15,1)$.

Cells are large, suboval, slightly asymmetrical in relation to the longitudinal axis of the cell, with a steeper posterior-ventral margin compared to the posteriordorsal one, with coarsely reticulate theca. The epitheca is high and narrowly rounded at the apex. LSL is long and narrow, ending relatively close to the antapex, with barely visible supporting ribs. RSL is about half the length of LSL, forming an 

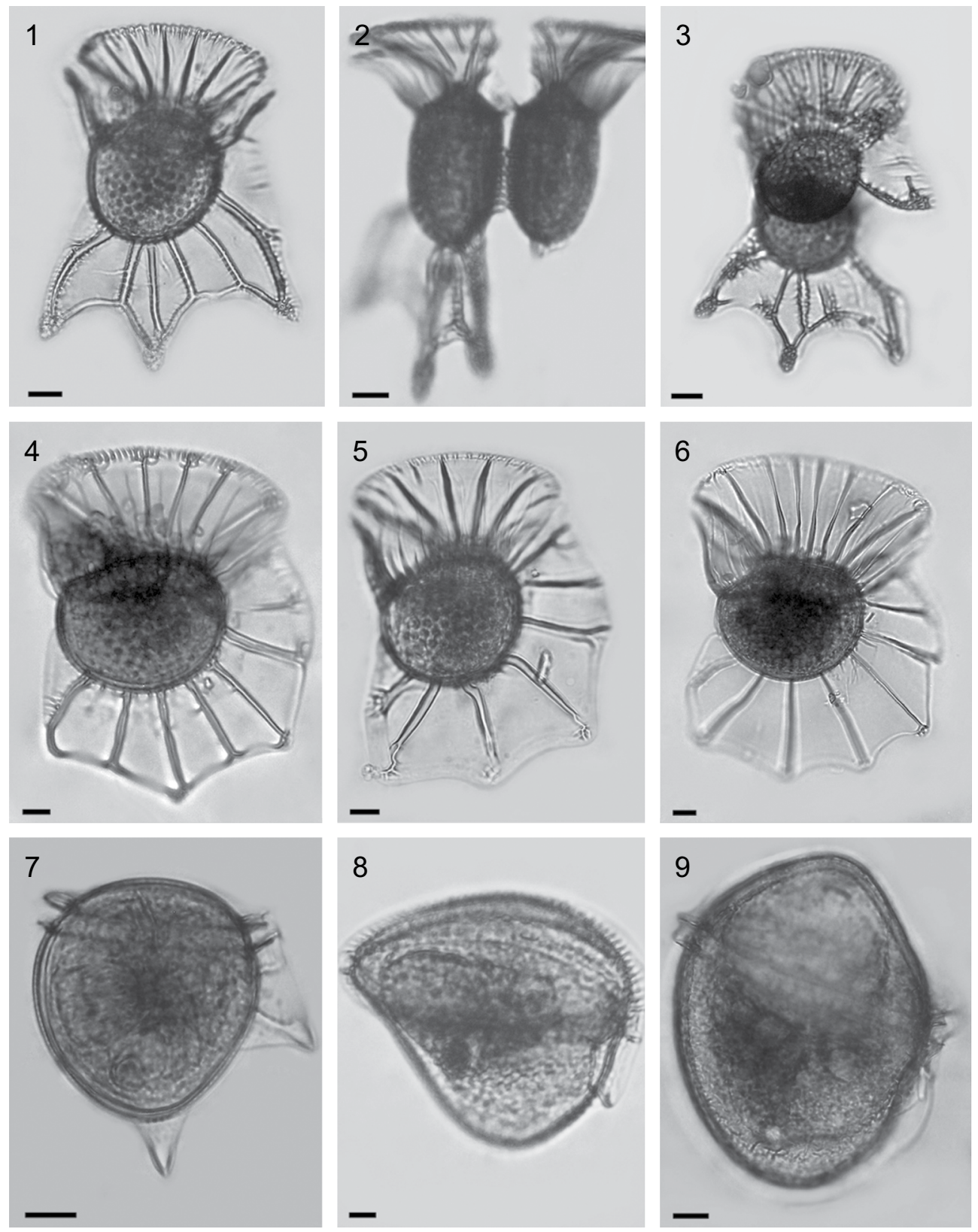

Plate 5. Fig. 1-3. Ornithocercus magnificus (2 and 3 - recently divided cells). Fig. 4. Ornithocercus thumii. Fig. 5. Ornithocercus skogsbergii. Fig. 6. Ornithocercus steinii. Fig. 7. Phalacroma doryphorum. Fig. 8. Phalacroma cuneus. Fig. 9. Phalacroma apicatum. Scale bar: $10 \mu \mathrm{m}$. 
inferior concavity bordered with a thickened crest. Lb $95-102 \mu \mathrm{m}(98 \pm 2.7 \mu \mathrm{m}), \mathrm{Db}$ 75-82.5 $\mu \mathrm{m}(78.5 \pm 2.2 \mu \mathrm{m})$, Dt 82.5-92 (87.6 $\pm 2.7 \mu \mathrm{m}) ; \mathrm{n}=7$.

Affinities. The species is morphologically similar to $P$. argus, distinguished from the latter by (1) its narrower rounded epitheca at the apex, (2) larger cell size, (3) higher L:D ratio, and (4) longer LSL.

A new record for the State of Veracruz. Extremely rare in NPSAV; the species was found only on 26 October 2005 at St. 3 (AVM).

References: Kofoid \& Skogsberg, 1928*: 111, fig. 10; Schiller, 1933*: 76, fig. 68a-c (after Kofoid \& Skogsberg, 1928); Pesantes-Santana, 1978*: 29, pl. 18, fig. 2; Taylor, 1976*: 33, pl. 4, fig. 36; Hernández-Becerril et al., 2008**: 3, fig. 4; EsquedaLara \& Hernández-Becerril, 2010**: 143, fig. 136.

4. Phalacroma argus F. Stein, 1883 (Pl. 6, Fig. 1; Pl. 13, Fig. 2). Syn.: Dinophysis argus (F. Stein) T. H. Abé, 1967 (Publ. Seto Mar. Biol. Lab. 15, 1), pro parte: 71, non fig. 23a, b.

Cells are large, oval, symmetrical in relation to the longitudinal axis of the cell, with coarsely reticulate theca. The epitheca is high and broadly rounded. LSL is of moderate length and narrow, with barely visible supporting ribs. RSL is about two-thirds of LSL in length, forming an inferior concavity bordered with a thickened crest. Lb 80-82.5 $\mu \mathrm{m}(81.3 \pm 1.8 \mu \mathrm{m}), \mathrm{Db} 70-71.5 \mu \mathrm{m}(70.8 \pm 1.1 \mu \mathrm{m})$, Dt 76.5-80 $\mu \mathrm{m}(78.3 \pm 2.5 \mu \mathrm{m}) ; \mathrm{n}=2$.

Morphological note. Unlike Stein (1883: pl. 18, fig. 16), Schütt (1895: pl. 3, fig. 15), Balech (1988: pl. 11, fig. 9, 10) and Taylor (1976: pl. 4, fig. 35) illustrate the cells of this species with a slightly asymmetrical cell shape in lateral view, with a steeper posterior-ventral margin. The species illustrated by Licea et al. (1995: 18, pl. 1, fig. 1) as $D$. argus is a misidentification. Most likely, it was confused with Phalacroma rotundata.

Records in the State of Veracruz: Okolodkov et al., 2011. Extremely rare in NPSAV; the species was found only on 26 October 2005 at St. 3 (AVM).

References: Stein, 1883*: pl. 18, fig. 15-17; Kofoid \& Skogsberg, 1928*: 104, fig. 8(1, 2), 9; Schiller, 1933*: 74, fig. 67a (after Kofoid \& Skogsberg, 1928); Rampi, 1940*: 15, fig. 17; Taylor, 1976*: 33, pl. 4, fig. 35 (as D. argus); Pesantes-Santana, 1978*: 29, pl. 18, fig. 3; Steidinger \& Tangen, 1996*: 437, pl. 14; Hernández-Becerril et al., 2008**: 3, fig. 5; Esqueda-Lara \& Hernández-Becerril, 2010**: 144, fig. 137a-c.

5. Phalacroma hindmarchii G. Murray et Whitting, 1899 (Pl. 6, Fig. 2; Pl. 13, Fig. 3). Syn.: Dinophysis hindmarchii (G. Murray et Whitting) Balech, 1967 (Rev. Mus. Argent. Cienc. Natur. "B. Rivadavia" Hidrobiol. 2, 3): 83. 
Cells of moderate size, inverted fig-shaped, almost symmetrical in relation to the longitudinal axis of the cell, with the theca bearing numerous scattered pores. Epitheca is high, very broadly rounded. Hypotheca is mostly with convex sides, with well-separated antapical bulb directed posteriorly. LSL is moderately wide. R3 is club-shaped, the longest and the thickest among three supporting ribs. The distance between R2 and R3 is aproximately 1.5 times greater than that between R1 and R2. RSL is narrow, terminating just behind R3. Lb 85-90 $\mu \mathrm{m}(86.7 \pm 1.9 \mu \mathrm{m}), \mathrm{Db} 70-97.5$ $\mu \mathrm{m}(75.1 \pm 9.9 \mu \mathrm{m})$, Dt 77.5-106.5 $\mu \mathrm{m}(83.8 \pm 10.2 \mu \mathrm{m}) ; \mathrm{n}=7$.

Records in the State of Veracruz: Zamudio-Resendiz, 1998 (as D. cf. hindmarchii). Extremely rare in NPSAV; the species was found only on 26 October 2005 at St. 3 (AVM).

References: Murray \& Whitting, 1899*: 330, pl. 31, fig. 5; Kofoid \& Skogsberg, 1928*: 150, fig. 18, 19; Schiller, 1933*: 92, fig. 84a-c; Balech, 1962*: 130, pl. 17, fig. 243-246; Hernández-Becerril et al., 2008**: 6, fig. 14.

6. Phalacroma rapa F. Stein, 1883 (Pl. 6, Fig. 3; Pl. 9, Fig. 1; Pl. 13, Fig. 4). Syn.: Dinophysis rapa (F. Stein) T. H. Abé, 1967 (Publ. Seto Mar. Biol. Lab. 15, 1): 66, fig. 19.

Cells are large, strongly asymmetrical in relation to the longitudinal axis of the cell, with coarsely areolated theca. Epitheca is broadly rounded. Hypotheca is cuneate in its posterior portion, with a markedly attenuated antapex tilted toward the ventral part of the cell, dorsally convex, narrowly rounded at the antapex, and strongly concave between the antapex and LSL. LSL is wide, ending far from the antapex. The distance between R2 and R3 is equal to the distance between R1 and $\mathrm{R} 2$ or slightly longer. $\mathrm{R} 3$ is about twice as long as R1 and about 1.5 times longer than R2. RSL is rather wide, ending just behind R3. Lb 65-82.5 $\mu \mathrm{m}(78.0 \pm 3.9 \mu \mathrm{m}), \mathrm{Db}$ 50-67.5 $\mu \mathrm{m}(61.1 \pm 3.8 \mu \mathrm{m})$, Dt $64-82.5 \mu \mathrm{m}(73.9 \pm 4.8 \mu \mathrm{m}) ; \mathrm{n}=31$.

Affinities. The species is similar to $P$. mitra, distinguished from the latter mainly by its size and more pronouncedly emerging posterior portion of the hypotheca.

Records in the State of Veracruz: Okolodkov et al., 2011; Parra-Toriz et al., 2011**. Rare in NPSAV (Oct., Nov., Dec.).

References: Stein, 1883*: pl. 19, fig. 5-8; Pavillard, 1916*: 55, fig. 13A; Kofoid \& Skogsberg, 1928*: 139, fig. 16; Schiller, 1933*: 88, fig. 80a-d (after Kofoid \& Skogsberg, 1928); Rampi, 1940*: 16, fig. 23; Silva, 1956*: 355, pl. 3, fig. 4; Taylor, 1976****: 40, pl. 5, fig. 48a, b, pl. 41, fig. 488; Pesantes-Santana, 1978*: 
29, pl. 18, fig. 5, 6; Hallegraeff \& Lucas, 1988***: fig. 6, 19; Delgado \& Fortuño, 1991***: 5, pl. 35, fig. a, b; Licea et al., 1995**: 21, pl. 6, fig. 6; Steidinger \& Tangen, 1996*: 439, pl. 14; Hansen et al., 2001**: 31, pl. 2, fig. G; Hernández-Becerril et al., 2008**: 6, fig. 23, 24; Esqueda-Lara \& Hernández-Becerril, 2010**: 153, fig. 146a-c.

7. Phalacroma mitra F. Schütt, 1895 (Pl. 6, Fig. 4; Pl. 13, Fig. 5). Syn.: Dinophysis mitra (F. Schütt) T. H. Abé, 1967 (Publ. Seto Mar. Biol. Lab. 15, 1): 63, fig. 18(1, 2).

Cells are small, wedge-shaped, strongly asymmetrical in relation to the longitudinal axis of the cell, with coarsely areolated theca. Epitheca is broadly rounded. Hypotheca is cuneate in its posterior portion, dorsally convex, narrowly rounded at the antapex, and slightly concave between the antapex and LSL. LSL is wide, ending far from the antapex. The distance between R2 and R3 is equal to the distance between R1 and R2 or slightly longer. R3 is about twice as long as R1 and about 1.5 times longer than R2. RSL is rather wide, ending just behind R3. Lb 47.5-50 $\mu \mathrm{m}$

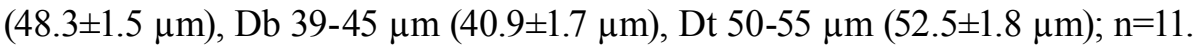

Records in the State of Veracruz: Okolodkov et al., 2011. Rare in NPSAV (Feb., Oct., Dec.).

References: Schütt, 1895: pl. 4, fig. 18(1, 4); Murray \& Whitting, 1899*: 330, pl. 31, fig. 7; Pavillard, 1916*: 53, fig. 13B, 14, pl. 3, fig. 9; Abé, 1927*: 385, fig. 3AE; Schiller, 1933*: 90, fig. 82a-c (after Murray \& Whitting, 1899); Rampi, 1940*: 17, fig. 25; Yamaji, 1966*: 67, pl. 31, fig. 19; Taylor, 1976*: 39, pl. 5, fig. 49; Delgado \& Fortuño, 1991****: fig. 4G, pl. 35, fig. c, d; Steidinger \& Tangen, 1996*: 439, pl. 14; Faust \& Gulledge, 2002******: 29, pl. 15, fig. 1-6; Larsen \& Nguyen, 2004**: 70, pl. 4, fig. 1-4; Hernández-Becerril et al., 2008*****: 6, fig. 18, 19; Al-Kandari et al., 2009**: 152, pl. 4, fig. A-G (p. 301).

8. Phalacroma equalanti (Balech) Okolodkov comb. nov. (P1. 6, Fig. 5; P1. 9, Fig. 2-4; Pl. 13, Fig. 6). Bas.: Dinophysis equalanti Balech, 1971 (Publ. Serv. Hidrogr. Naval B. Aires H 654): 9, pl. 4, fig. 51-63.

Cells are small, suboval, markedly asymmetrical in relation to the longitudinal axis of the cell, with a convex dorsal side and a compressed ventral side, with a rather high, broadly rounded epitheca and narrower rounded antapex. Epitheca is about one-quarter $(0.22-0.25)$ of the cell length. LSL is wide, ending far from the antapex. The distance between R2 and R3 is about half the distance between R1 
and R2, which distinguishes this species from many others. RSL is rather wide, ending about half-way between R3 and the posterior end of LSL. Lb 31.5-48.5 $\mu \mathrm{m}(42.0 \pm 3.1 \mu \mathrm{m}), \mathrm{Db} 27.5-42.5 \mu \mathrm{m}(35.6 \pm 2.4 \mu \mathrm{m})$, Dt 34-52.5 $\mu \mathrm{m}(42.4 \pm 2.7 \mu \mathrm{m})$; $\mathrm{n}=43$.

Morphological note. Our specimens correspond well to the original description and figures by Balech (1971b), based on the specimens from the western equatorial Atlantic; however, the former are distinguished by RSL extending further backward, almost to the point where LSL ends. As Balech stresses, the position of R2 closer to R3 rather than to R1 is a constant feature, which distinguishes $P$. equalanti from the morphologically similar $P$. operculoides F. Schütt and $P$. parvulum (F. Schütt) Jörg., and $P$. equalanti is much more frequent than it appears in species lists. The species is also very similar to P. scrobiculata (Balech) Díaz-Ramos et Estrella in Díaz-Ramos (Balech, 1988: 46, pl. 9, fig. 5, 6) that inhabits subantarctic waters in the cell shape and size and the proximity of R2 to R3. However, the latter has a weaker curvature of the posterior portion of the dorsal margin of the hypotheca in lateral view.

Nomenclatural note. A new combination, Phalacroma equalanti (Balech) Okolodkov comb. nov., is proposed here, on the basis of a relatively high epitheca and subhorizontal cingular lists characteristic of the genus Phalacroma, which distinguishes it from Dinophysis.

Records in the State of Veracruz: Parra-Toriz et al., 2011*****: 510, fig. 14-16 (mistakenly reported as $P$. rotundata). Rare to common in NPSAV (Feb., Apr., May, Oct., Nov., Dec.), easily overlooked in the samples. Along with P. rotundatum, one of the most common species of the genus Phalacroma in the study area.

References: Balech, 1971b*: 9, pl. 4, fig. 51-63 (as D. equalantii n. sp.); Pesantes-Santana, 1978*: 28, pl. 18, fig. 7(?) (possibly a misidentification; referred to as $P$. ovum).

9. Phalacroma rotundatum (Clap. et J. Lachm.) Kof. et J. R. Michener, 1911 (Pl. 6, Fig. 6; Pl. 13, Fig. 7). Bas.: Dinophysis rotundata Clap. et J. Lachm., 1859: 6, pl. 20, fig. 16. Syn.: Prodinophysis rotundata (Clap. et J. Lachm.) Balech, 1944: 429.

Cells are of moderate size, oval, symmetrical in relation to the longitudinal axis of the cell, with smooth poroid theca. Both epitheca and hypotheca are broadly rounded. LSL is rather narrow, ending far from the antapex. The distance between $\mathrm{R} 2$ and $\mathrm{R} 3$ is about 1.5 the distance between $\mathrm{R} 1$ and $\mathrm{R} 2$. R3 is about twice as long as R1 and about 1.5 times longer than R2. All the ribs of LSL are about equal in 
length. RSL is narrow, ending close to R3. Lb 37.5-42.5 $\mu \mathrm{m}(40.0 \pm 3.5 \mu \mathrm{m}), \mathrm{Db} 35.0$, Dt 37.5-40 $\mu \mathrm{m}(38.8 \pm 1.7 \mu \mathrm{m}) ; \mathrm{n}=2$.

Morphological note. The species illustrated by Licea et al. (1995: 21, pl. 6, fig. 7) under the name of Dinophysis rotundata seems to be a misidentification. Judging from the well-developed right sulcal list with a rather long third rib and the small size of the cell (about $30 \mu \mathrm{m}$ ), the species can be P. parvulum (Schütt) Jörg. (see Balech, 1988: 49, pl. 10, fig. 4).

Records in the State of Veracruz: García-Reséndiz, 2003 (as Dinophysis rotundata ?); Estradas-Romero, 2004; Tejeda-Hernández, 2005**; Hernández-Becerril et al., 2008; Okolodkov et al., 2011. Rare to common in NPSAV (Apr., May, July, Aug., Oct., Dec.).

References: Stein, 1883*: pl. 19, fig. 9-11, pl. 20, fig. 1, 2; Paulsen, 1908*: 17, fig. 18 (after Stein, 1883); Meunier, 1910*: 59, pl. 3, fig. 43-46; Pavillard, 1916*: 58, pl. 3, fig. 5; Lebour, 1925*: 78, pl. 11, fig. 3a-c; Abé, 1927*: 385, fig. 2; 1967: 57, fig. 15a-h; Kofoid \& Skogsberg, 1928*: Paulsen, 1931*: 32, fig. 17; Schiller, 1933*: 63, fig. 60a-c (after Lebour, 1925), d; Tai \& Skogsberg, 1934*: 426, fig. 2A-L; Böhm, 1936*: 15, fig. 5a; Rampi, 1940*: 14, fig. 16; Balech, 1962*: 124, pl. 16, fig. 204; Yamaji, 1966*: 68, pl. 31, fig. 21; Hermosilla, 1973*: 9, pl. 1, fig. 16-18; Drebes, 1974**: 116, fig. 94d; Dodge, 1982****: 55, fig. 4I, pl. 2, fig. f; 1985***: 27; Larsen \& Moestrup, 1989**: 22, fig. 7a-c; Delgado \& Fortuño, 1991***: 5, pl. 37, fig. b; Steidinger \& Tangen, 1996*: 439, pl. 14; Bérard-Therriault et al., 1999*****: 147, pl. 64, fig. c, f; Faust \& Gulledge, 2002******: 32, pl. 17, fig. 1-5; Hernández-Becerril et al., 2008**: 6, fig. 25; Al-Kandari et al., 2009**: 153, pl. 4, fig. I (p. 301); Hoppenrath et al., 2009** ***: 194, fig. 771-o.

\section{Genus Sinophysis Nie et Wang}

Key for identification of Sinophysis species

1a Cells almost subglobular, with LSL slightly shorter than the cell length, epitheca small and not tilted dorsally

(1) Sinophysis microcephala

$1 \mathrm{~b}$ Cells suboval, elongated, with LSL of about $0.5-0.6$ cell length, epitheca very small, dorsally tilted

2a Cells slightly elongated, with LSL of about 0.65-0.75 hypotheca length 
$2 \mathrm{~b}$ Cells strongly elongated, with LSL of about 0.5 hypotheca length

(3) Sinophysis stenosoma

1. Sinophysis microcephala Nie et Wang, 1944 (Pl. 6, Fig. 7; Pl. 13, Fig. 8).

Cells are suboval, slightly longer than wide, almost symmetrical in relation to the longitudinal axis of the cell, with coarsely areolated theca. The epitheca is small, not inclined dorsally. ACL is narrow, lower than the epitheca, not emerging from the epitheca anteriorly. Hypotheca is convex dorsally and ventrally in lateral view, very widely rounded posteriorly. LSL is well distinguished in right-side view, expanding significantly onto the right side of the cell, undulated, S-shaped. The sulcus length is about 2/3-3/4 the cell length. Lb 42 $\mu \mathrm{m}, \mathrm{Db} 33 ; \mathrm{n}=1$.

Morphological note. The species is similar to $S$. canaliculata in lateral view; however, it lacks the short cut of the theca in the middle portion of the left hypothecal plate clearly visible under the light microscope in $S$. canaliculata (Quod et al., 1999: fig. 3; Hansen et al., 2001: pl. 1, fig. E; Mohammad-Noor et al., 2007: fig. 24c; Escalera et al., 2011: fig. 1C). Although epifluorescence microscopy was not applied in our study, all the examined cells (several dozens) of $S$. microcephala from Veracruz seemed to contain cyanobacterial symbionts, similar to those found in $S$. canaliculata (Escalera et al., 2011).

Records in the State of Veracruz: Okolodkov et al., 2007**. Rare species in NPSAV (May, July, Aug., Nov.), the most common species of the genus Sinophysis in the study area.

References: Nie \& Wang, 1944*: 148, fig. 1-8; Faust, 1993*****: 356, fig. 1-11; Steidinger \& Tangen, 1996*: 442, pl. 17; Quod et al., 1999******: 87, fig. 1-16; Hoppenrath, 2000*: 163, fig. 42; Mohammad-Noor et al., 2007*****: 660, fig. 25a-h; Al-Yamani \& Saburova, 2010***: 50, pl. 11, fig. a-k; Escalera et al., 2011** ***: 306 , fig. 1,3 .

2. Sinophysis ebriola (Herdman) Balech, 1956 (P1. 6, Fig. 8; P1. 13, Fig. 9). Bas.: Phalacroma ebriola Herdman, 1924: 79, fig. 24. Syn.: Thecadinium ebriolum Kof. et Skogsb., 1928: 32.

Cells are suboval, markedly longer than wide, asymmetrical in relation to the longitudinal axis of the cell, with a thin smooth theca. The epitheca is very small, tilted toward the dorsal part of the cell. ACL is relatively wide, higher than the 

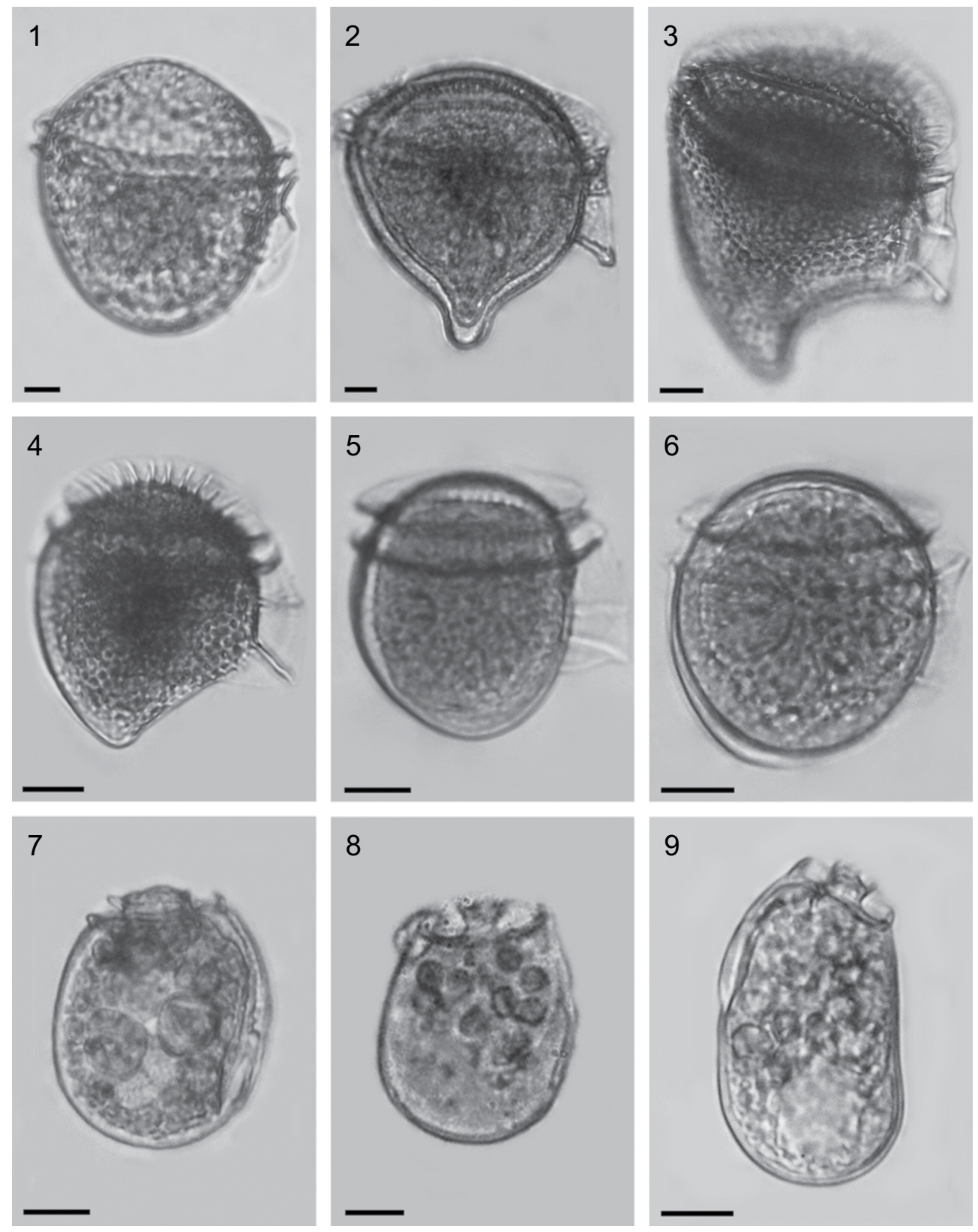

Plate 6. Fig. 1. Phalacroma argus. Fig. 2. Phalacroma hindmarchii. Fig. 3. Phalacroma rapa. Fig. 4. Phalacroma mitra. Fig. 5. Phalacroma equalanti. Fig. 6. Phalacroma rotundatum. Fig. 7. Sinophysis microcephala. Fig. 8. Sinophysis ebriolum. Fig. 9. Sinophysis stenosoma. Scale bar: $10 \mu \mathrm{m}$. 
epitheca. Hypotheca is straight or nearly straight dorsally and convex ventrally in lateral view, widely rounded posteriorly. LSL is poorly distinguished in right-side view, and it is more than half the hypotheca length. Lb $25-33 \mu \mathrm{m}(28.9 \pm 3.0 \mu \mathrm{m}), \mathrm{Db}$ 20-22.5 $\mu \mathrm{m}(21.0 \pm 1.2 \mu \mathrm{m}) ; \mathrm{n}=7$.

Records in the State of Veracruz: Okolodkov et al., 2007**. Extremely rare in NPSAV (Jan., May, Dec.).

References: Lebour, 1925*: 77, text-fig. 20c (as Phalacroma ebriolum, after Herdman, 1924); Schiller, 1933*: 51, fig. 50 (as Thecadinium ebriolum); Balech, 1956*: 21, fig. 9-22; Dodge, 1982*: 56, fig. 3D; Saunders \& Dodge, 1984*****: 273,
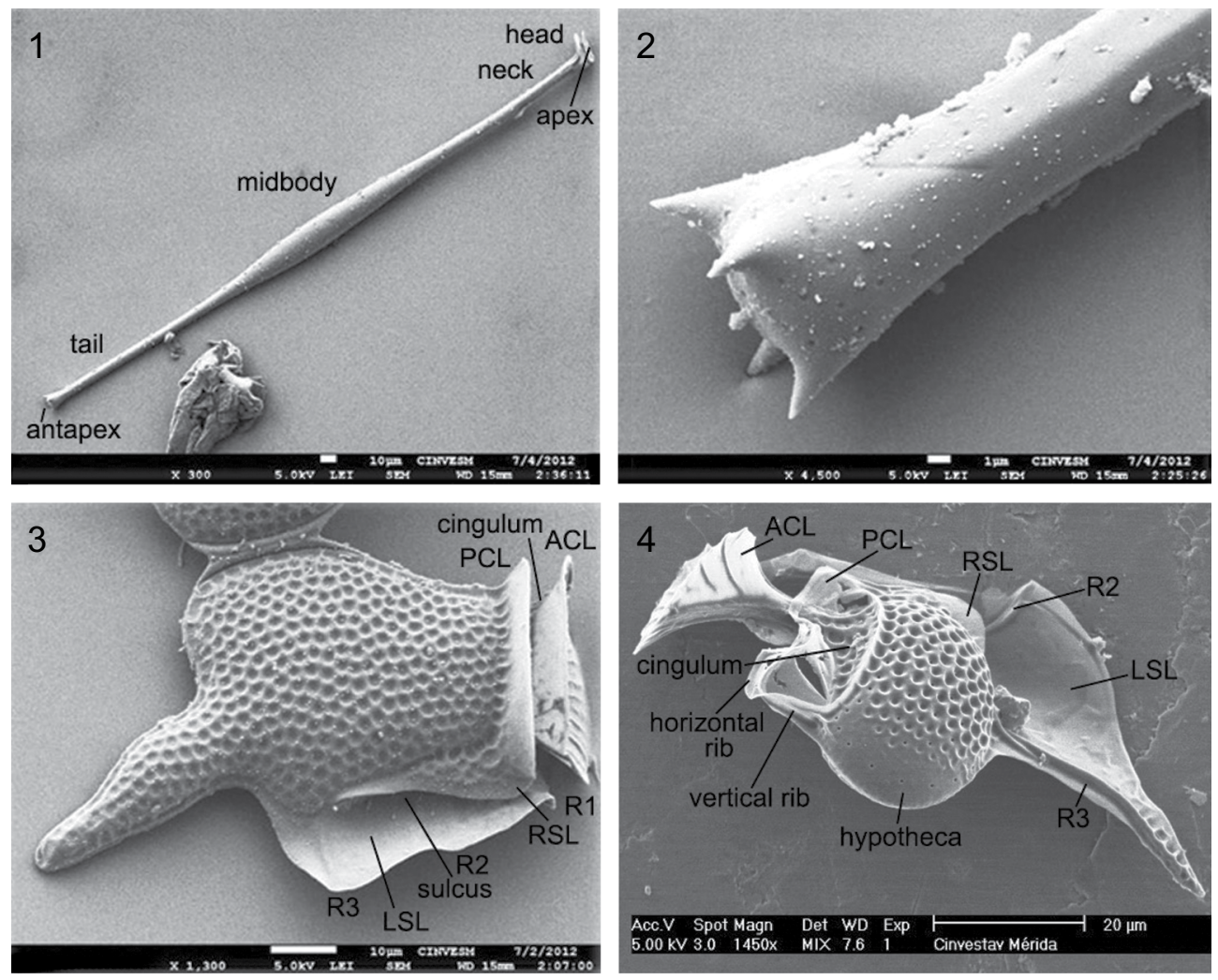

Plate 7. Scanning electron micrographs of some Dinophysiales species. Fig. 1 and 2. Amphisolenia schauinslandii (2 - posterior part). Fig. 3. Dinophysis caudata var. pedunculata. Fig. 4. Histioneis isseli. Abbreviations: ACL - anterior cingular list; LSL left sulcal list; PCL - posterior cingular list; R1 - first rib, R2 - second rib, R3 - third rib; $\mathrm{RSL}$ - right sulcal list. 
fig. 2, 8-11; Hoppenrath, 2000******: 154, fig. 1-3, 10-23; Selina \& Hoppenrath, 2004*****: 152, fig. 18-27, 56a; Al-Yamani \& Saburova, 2010***: 46, pl. 9, fig. a-k.

3. Sinophysis stenosoma Hoppenrath, 2000 (P1. 6, Fig. 9; P1. 13, Fig. 10).

Cells are suboval, significantly elongated, asymmetrical in relation to the longitudinal axis of the cell, with a thin smooth theca. The epitheca is very small, tilted toward the dorsal part of the cell. ACL is relatively wide, higher than the epitheca. Hypotheca is straight dorsally and convex ventrally in lateral view, narrowly rounded posteriorly. LSL is poorly distinguished in right-side view, and it is about half the hypotheca length. Lb 44-50 $\mu \mathrm{m}(47 \pm 4.2 \mu \mathrm{m}), \mathrm{Db} 25-27.5 \mu \mathrm{m}(26.3 \pm 1.7 \mu \mathrm{m}) ; \mathrm{n}=2$.
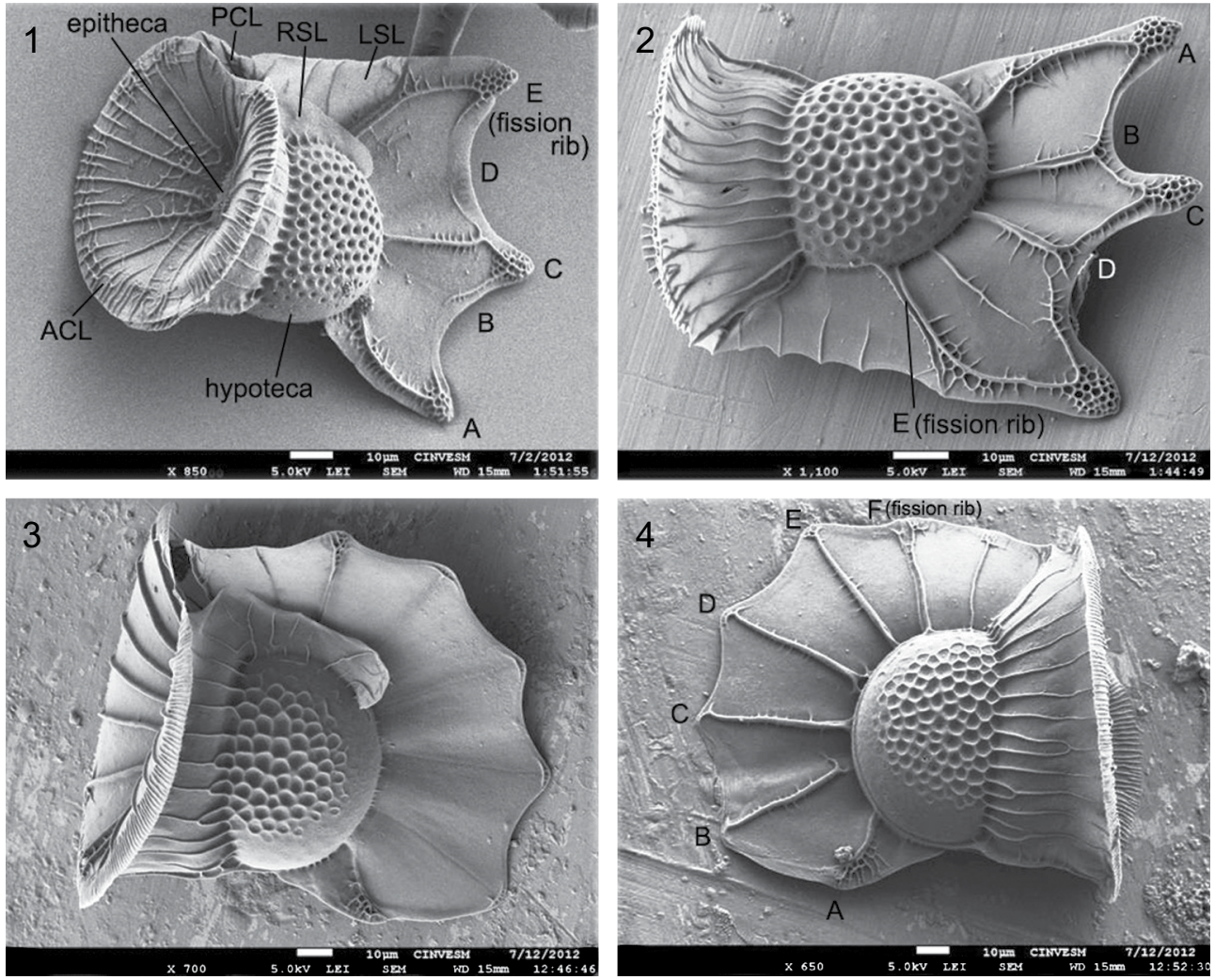

Plate 8. Scanning electron micrographs of some Dinophysiales species. Fig. 1 and 2. Ornithocercus magnificus (1 - right-side-apical view; 2 - left-side view). Fig. 3 and 4. Ornithocercus steinii (3- right-side view; 4 - left-side view). 
Affinities. The species is morphologically similar to S. ebriolum; however, it is usually more elongated. Hoppenrath (2000) reports a length/width ratio of 1.431.89 for S. stenosoma from the North Sea, and 1.2-1.5 for S. ebriolum, both from the North Sea. Selina \& Hoppenrath (2004) present ranges of 1.45-1.8 and 1.09-1.66, respectively, for the cells from the Sea of Japan.

Records in the State of Veracruz: Okolodkov et al., 2007**. Extremely rare in NPSAV (Jan., Aug., Dec.).

References: Hoppenrath, 2000******: 159, fig. 4-6, 24-33; Selina \& Hoppenrath, 2004*****: 152, fig. 42-54, 56c; Al-Yamani \& Saburova, 2010***: 52, pl. 12, fig. a-k.
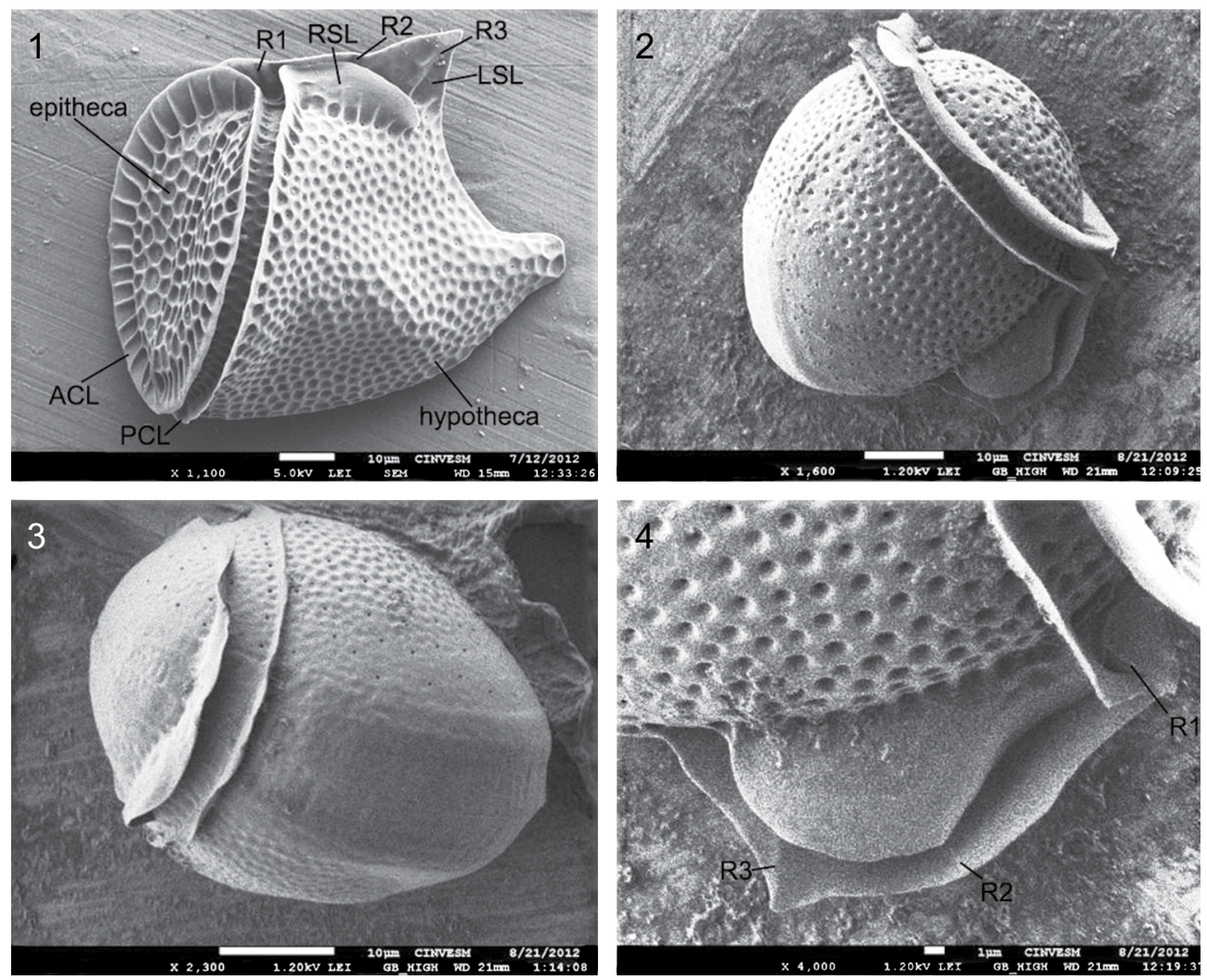

Plate 9. Scanning electron micrographs of some Dinophysiales species. Fig. 1. Phalacroma rapa. Fig. 2-4. Phalacroma equalanti (2 - right-side view; 3 - dorsal view of a megacytic cell; 4 - a fragment of the right hypothecal plate, the cingulum and the left and right sulcal lists). Abbreviations: ACL - anterior cingular list; LSL - left sulcal list; PCL - posterior cingular list; R1 - first rib, R2 - second rib, R3 - third rib; RSL - right sulcal list. 
Okolodkov: Dinophysiales of the National Park Sistema Arrecifal Veracruzano
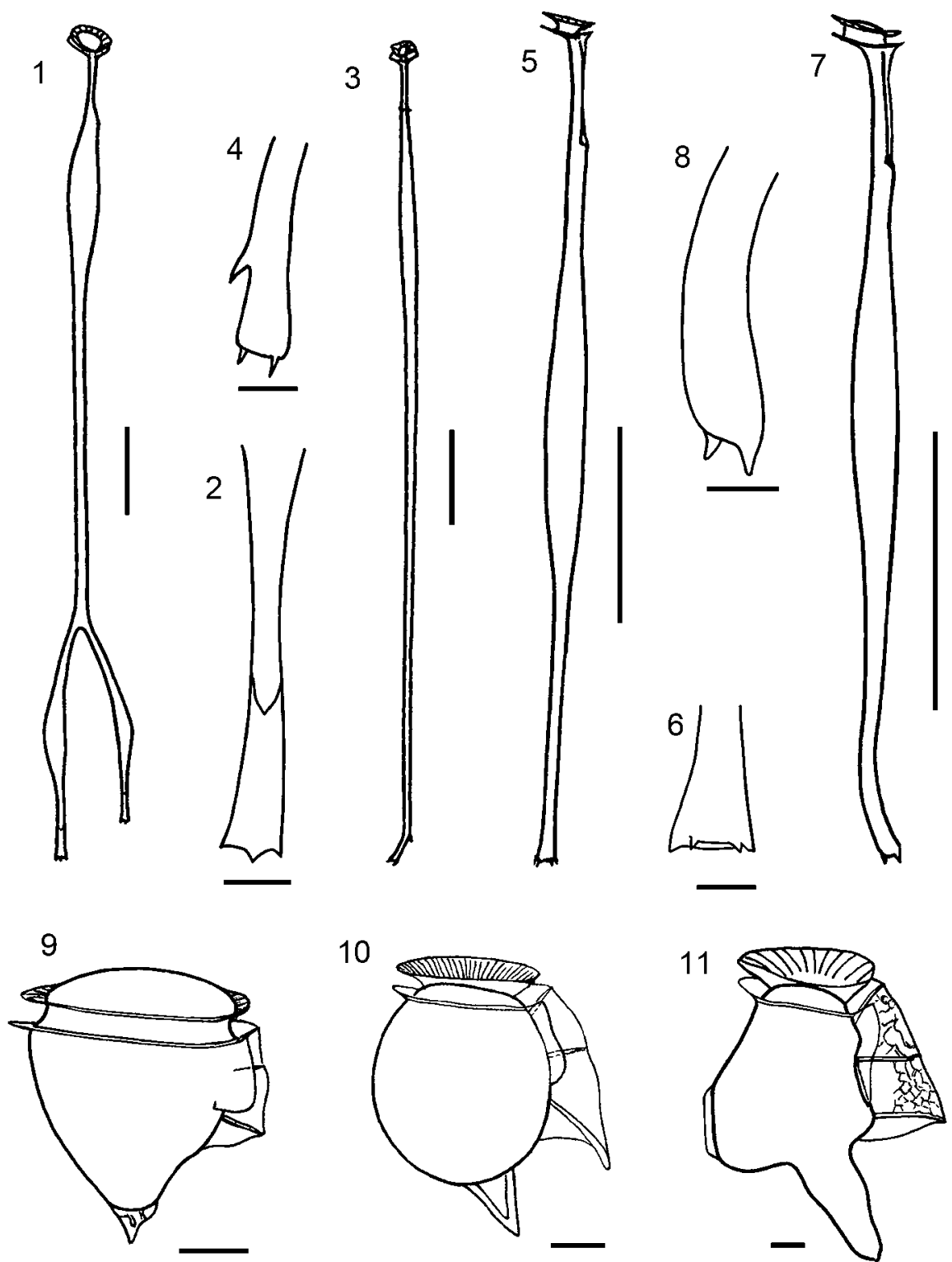

10

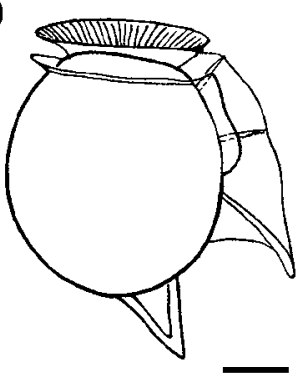

11

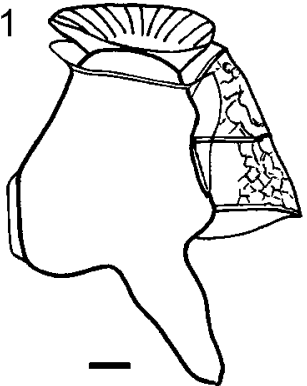

Plate 10. Fig. 1 and 2. Amphisolenia bifurcata: 1 - cell, 2 - posterior part of the cell. Fig. 3 and 4. Amphisolenia bidentata: 3 - cell, 4 - posterior part of the cell. Fig. 5 and 6. Amphisolenia schauinslandii: 5 - cell, 6 - posterior part of the cell. Fig. 7 and 8. Amphisolenia schroederi: 7 - cell, 8 - posterior part of the cell. Fig. 9. Dinophysis capitulata. Fig. 10. Dinophysis hastata. Fig. 11. Dinophysis caudata var. pedunculata. Scale bars: $10 \mu \mathrm{m}$ in Fig. 2, 4, 6 and 8-11; $100 \mu \mathrm{m}$ in Fig. 1, 3, 5 and 7. 

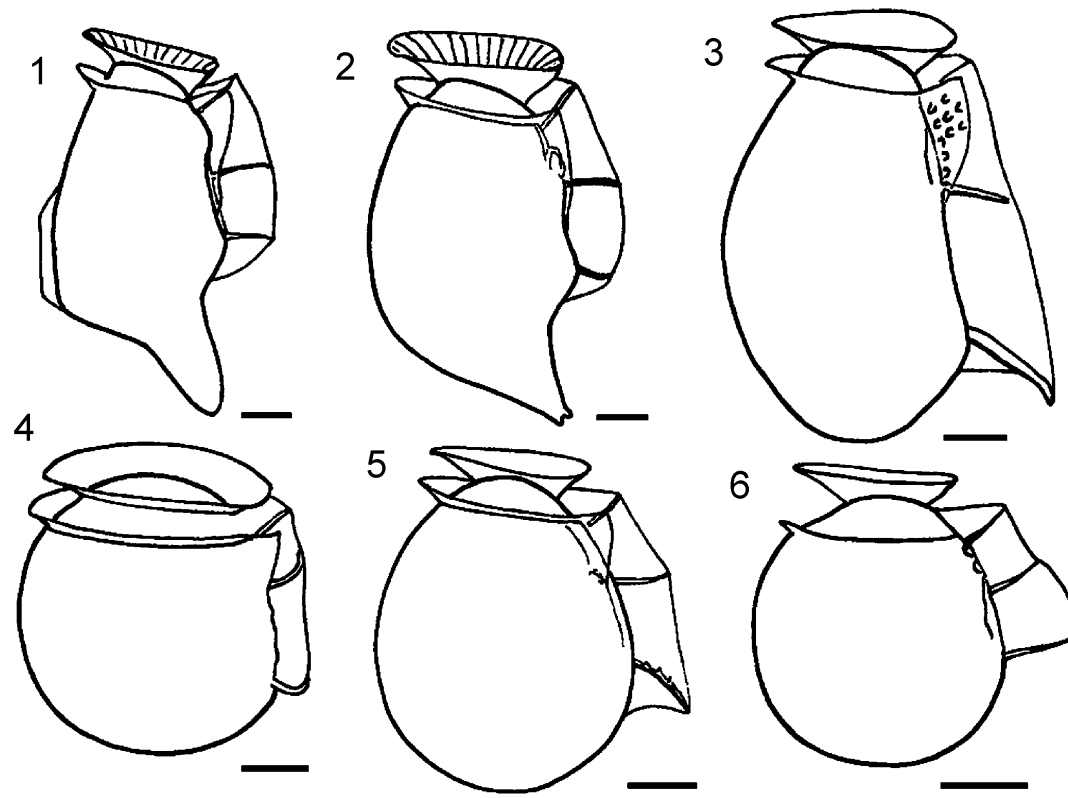

6
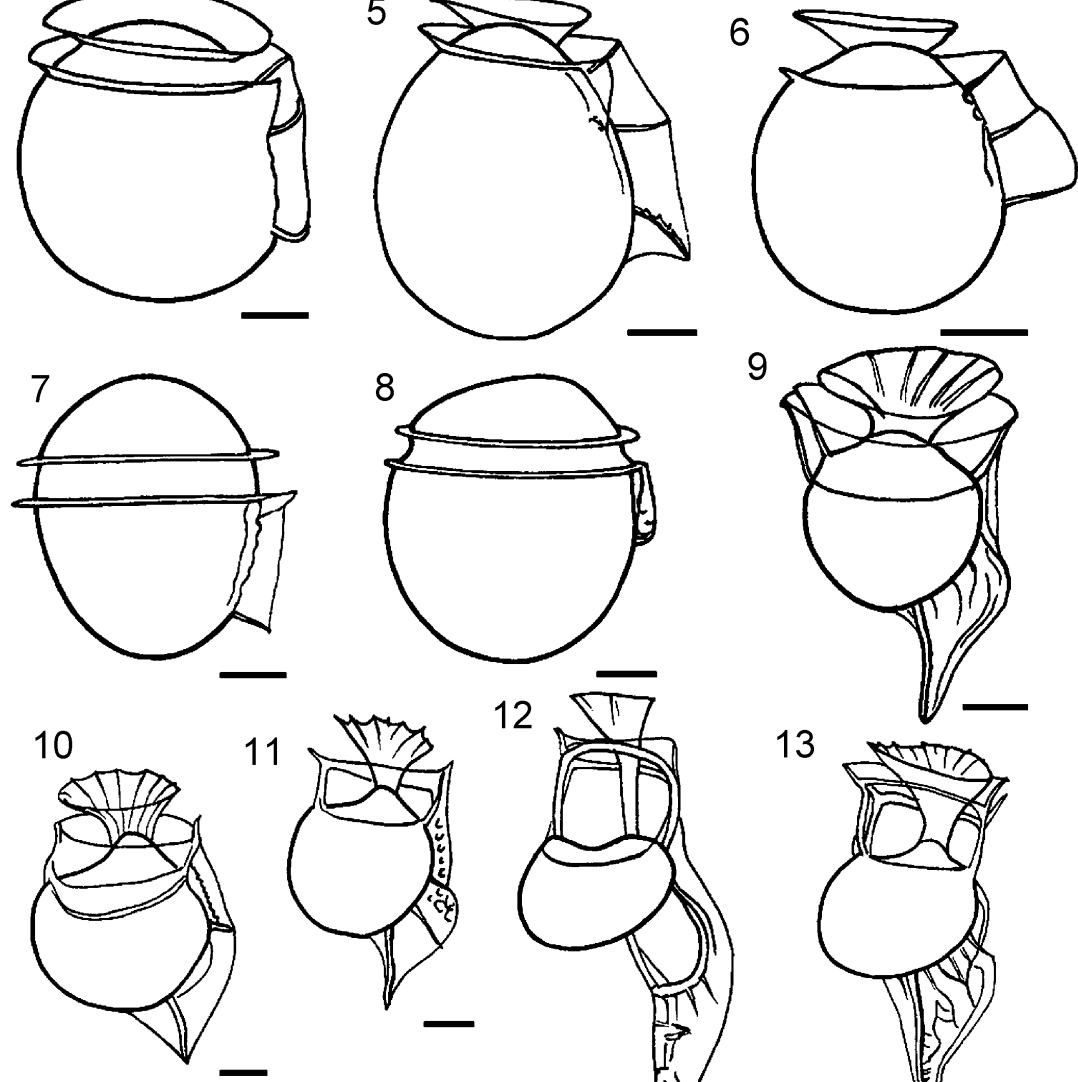

12
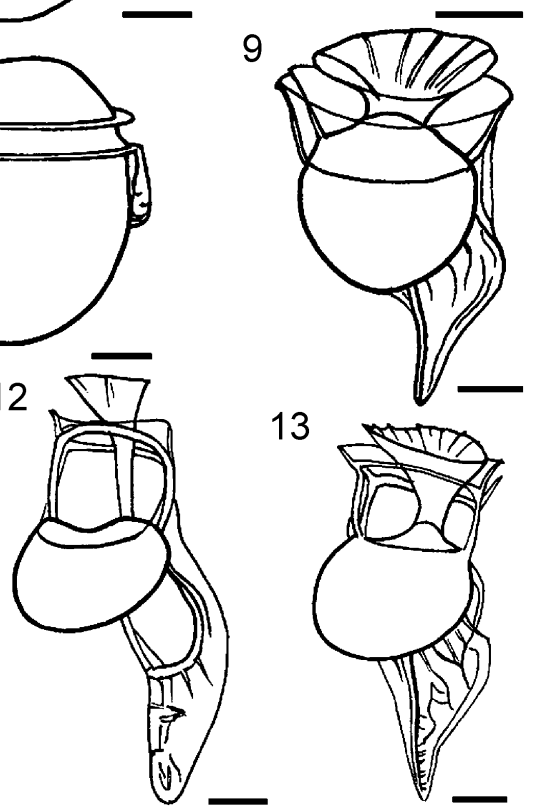

13

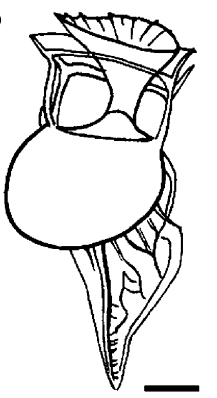

Plate 11. Fig. 1 and 2. Dinophysis caudata var. abbreviata. Fig. 3. Dinophysis schroederi. Fig. 4. Dinophysis cf. similis. Fig. 5. Dinophysis ovum. Fig. 6. Dinophysis cf. exigua. Fig. 7. Heteroschisma sp. Fig. 8. Pseudophalacroma nasutum. Fig. 9. Histioneis paraformis. Fig. 10. Histioneis crateriformis. Fig. 11. Histioneis karstenii. Fig. 12. Histioneis longicollis. Fig. 13. Histioneis isseli. Scale bar: $10 \mu \mathrm{m}$. 

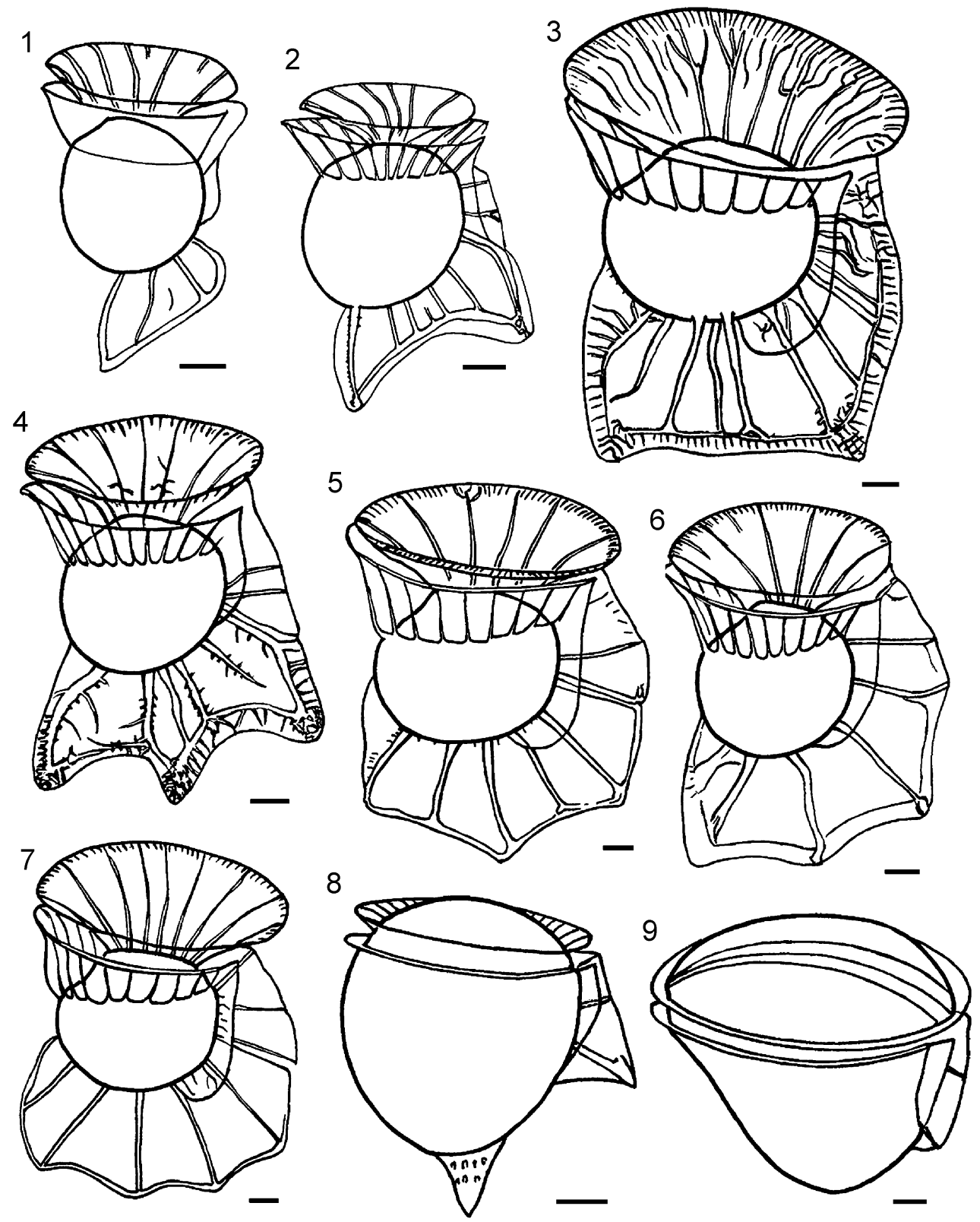

Plate 12. Fig. 1. Ornithocercus cristatus. Fig. 2. Ornithocercus heteroporus. Fig. 3. Ornithocercus quadratus. Fig. 4. Ornithocercus magnificus. Fig. 5. Ornithocercus thumii. Fig. 6. Ornithocercus skogsbergii. Fig. 7. Ornithocercus steinii. Fig. 8. Phalacroma doryphorum. Fig. 9. Phalacroma cuneus. Scale bar: $10 \mu \mathrm{m}$. 

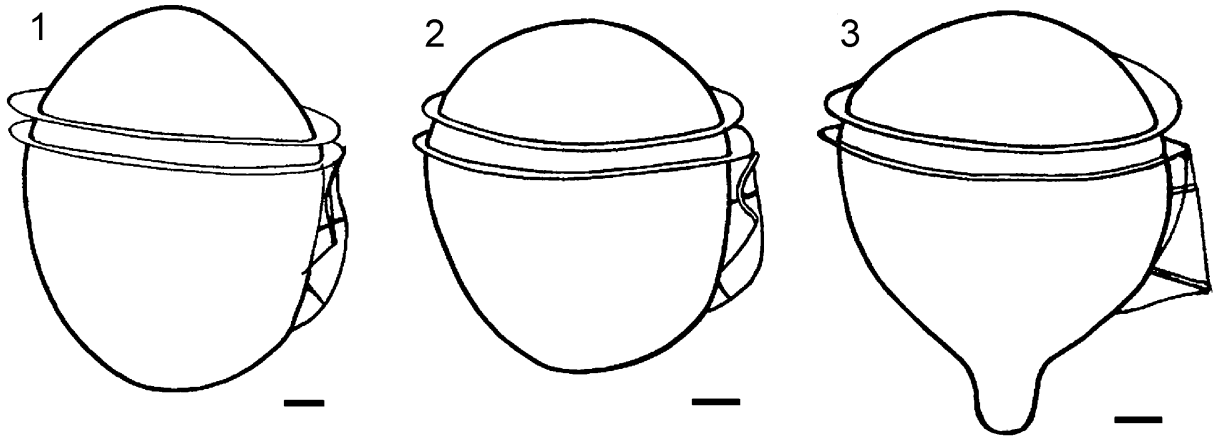

5
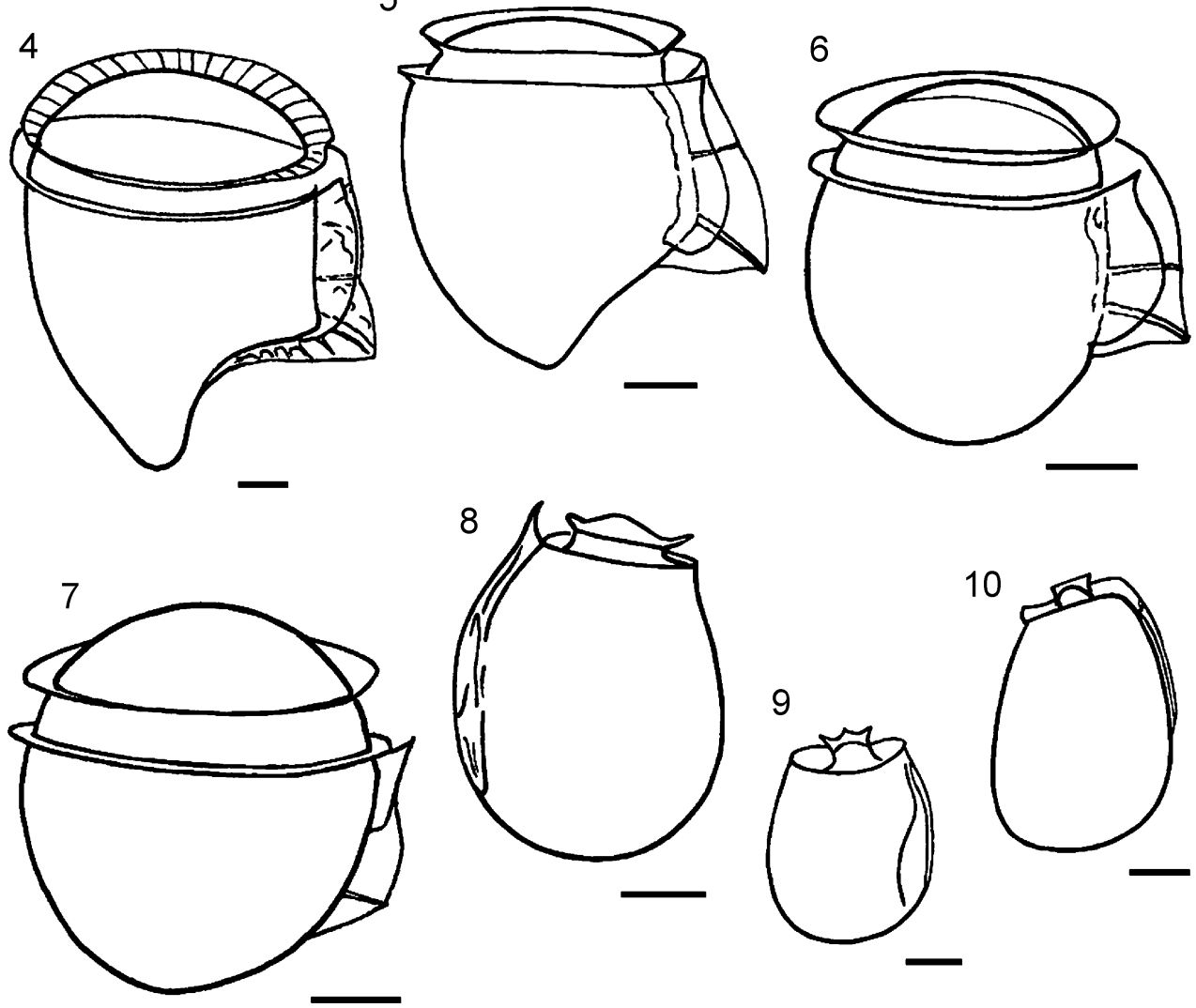

Plate 13. Fig. 1. Phalacroma apicatum. Fig. 2. Phalacroma argus. Fig. 3. Phalacroma hindmarchii. Fig. 4. Phalacroma rapa. Fig. 5. Phalacroma mitra. Fig. 6. Phalacroma equalanti. Fig. 7. Phalacroma rotundatum. Fig. 8. Sinophysis microcephala. Fig. 9. Sinophysis ebriolum. Fig. 10. Sinophysis stenosoma. Scale bar: $10 \mu \mathrm{m}$. 


\section{DISCUSSION}

In addition to the species illustrated in the present study, Zamudio-Resendiz (1998) reported Amphisolenia globifera F. Stein, Citharistes sp., Dinophysis pusilla Jørg., D. schuettii G. Murray et Whitting, H. joergensenii J. Schill., H. rotundata Kof. et J. R. Michener and H. striata Kof. et J. R. Michener from the northern Veracruz and southern Tamaulipas shelf waters (in total, 19 species of the order Dinophysiales). Figueroa-Torres \& Weiss-Martínez (1999) mentioned three Dinophysiales species including Oxyphysis oxytoxoides Kof. Avendaño-Sánchez \& SotomayorNavarro (1982) gave eight species names, among which Dinophysis monacantha Kof. et Skogsb. is the only record of this species for the State of Veracruz. EstradasRomero (2004) mentioned Amphisolenia lemmermannii Kof. and Oxyphysis oxytoxoides Kof. (misspelled as O. oxytoides). Suchil-Vilchis (1990) reported Dinophysis tripos from Laguna del Ostión, Veracruz. García-Reséndiz (2003) reported Ornithocercus splendidus F. Schütt from the westernmost area of the State of Tabasco, adjacent to the State of Veracruz. I observed a single cell of this species only once in the NPSAV, but due to the absence of photographic records, it is not presented in this article. Finally, Okolodkov et al. (2011) reported 21 Dinophysiales species from the NPSAV, including Dinophysis amandula Sournia, D. favus (Kof. et J. R. Michener) T. H. Abé, D. fortii, D. schuettii G. Murray et Whitting and Ornithocercus heteroporoides T. H. Abé. None of the species mentioned above was documented with illustrations.

Thirteen species are new records for the NPSAV; Histioneis isseli and Pseudophalacroma nasutum are new records for the Gulf of Mexico. Out of 38 illustrated species, 14 species (including all observed Histioneis species) were found only on 26 October 2006 at St. 3 (AVM), which can be explained by an anomolous intrusion of oceanic waters. In the autumn, the current pattern in the NPSAV is influenced by the northerlies more strongly than during other seasons, and it is ruled by both the wind and the meso-scale cyclonic eddy of the Campeche Bay (Salas-Pérez et al., 2012). Apart from this, the species composition of the Dinophysiales in the NPSAV remained rather stable. Taking into account all the records of dinophysioid dinoflagellates in the State of Veracruz, 54 species have been reported. New records of the dinophysioid species in the study area should be expected, primarily due to the occasional intrusion of oceanic waters rich in Amphisolenia, Citharistes, Histioneis, Ornithocercus and Triposolenia species, overlooked small Phalacroma species, and closely related and morphologically similar Dinophysis species, such as those belonging to the Dinophysis hastata and Dinophysis acuminata complexes. 


\section{ACKNOWLEDGMENTS}

Guadalupe Campos-Bautista, responsible for the red-tide project at the Acuario de Veracruz, A.C., is thanked for providing samples, and the Acuario de Veracruz is thanked for logistic support. Eduardo Morteo-Ortiz (the project financed by the "Programa para el Mejoramiento del Profesorado" (PROMEP) in 2006-2007) and Horacio Perez-España (the project "Fuentes orgánicas de carbon y nitrógeno y su function sobre la estructura trófica en el Sistema Arrecifal Veracruzano" financed by the program Fondos Mixtos, Consejo Nacional de Ciencia y Tecnología (FOMIX CONACYT) -Veracruz in 2007-2010) from the Instituto de Ciencias Marinas y Pesquerías (ICIMAP), Universidad Veracruzana, are also thanked for providing financial and logistic support. The help of Dora A. Huerta Quintanilla and Ana R. Cristóbal-Ramos from the Centro de Investigación y de Estudios Avanzados (CINVESTAV) (Merida, Yucatan, Mexico) with the scanning electron microscopes is very much appreciated. I am thankful to Marcia M. Gowing from the University of California at Santa Cruz, California, who kindly improved the writing style, and to Natalia Okolodkova who prepared illustrations for publication. Fany del Carmen Merino-Virgilio and Ana C. Aguilar-Trujillo of CINVESTAV are thanked for technical support. Mona Hoppenrath from the German Center for Marine Biodiversity Research, Wilhelmshaven, Germany, Ismael Gárate-Lizárraga from the Centro Interdisciplinario de Ciencias Marinas (CICIMAR), La Paz, Baja California Sur, Mexico, and David Salas-Monreal from ICIMAP are thanked for their help in obtaining some valuable literature. Critical comments of the two anonymous reviewers improved the quality of the manuscript. The financial support of Dirección General de Investigaciones de la Universidad Veracruzana, Mexico (the project "Algas de la zona arrecifal Veracruzana, Golfo de México, con énfasis en las algas rojas, diatomeas y dinoflagelados" in 2007-2009) is also appreciated. SEM observations in this study were supported by FOMIX-Yucatán No. 108160 and CONACYT LAB-2009-01 No. 123913 projects led by Patricia Quintana-Owen of CINVESTAV.

\section{LITERATURE CITED}

Abé, T. H. 1927. Report of the biological survey of Mutsu Bay. 3. Notes on the protozoan fauna of Mutsu Bay. I. Peridiniales. Sci. Rep. Tôhoku Imper. Univ., Sendai, Japan, Ser. 4, 2(4): 383-438. 
Abé, T. H. 1967a. The armoured Dinoflagellata: II. Prorocentridae and Dinophysidae (B) Dinophysis and its allied genera. Publ. Seto Mar. Lab. 15(1): 37-78.

Abé, T. H. 1967b. The armoured Dinoflagellata: II. Prorocentridae and Dinophysidae (C) - Ornithocercus, Histioneis, Amphisolenia and others. Publ. Seto Mar. Lab. 15(2): 79-116.

Al-Kandari, M., F. Al-Yamani \& K. Al-Rifaie. 2009. Marine phytoplankton atlas of Kuwait's waters. Kuwait Institute for Scientific Research. Safat, Kuwait. 350 pp.

Alonso-Rodríguez, R., D. U. Hernández-Becerril \& I. Gárate-Lizárraga. 2008. Catálogo de microalgas de las lagunas costeras de Sinaloa. Serie Lagunas Costeras de Sinaloa 4. Universidad Nacional Autónoma de Mexico. México, D.F., México. 198 pp.

Al-Yamani, F. \& M. A. Saburova. 2010. Illustrated guide on the flagellates of Kuwait's intertidal soft sediments. Kuwait Institute for Scientific Research. Safat, Kuwait. iv $+197 \mathrm{pp}$.

Aquino-Cruz, A. 2002. Presencia de dinoflagelados (Pyrrhophyta), con énfasis en productoras potenciales de marea roja, en Playa Paraíso, Ver. Tesis Profesional. Facultad de Biología, Universidad Veracruzana. Xalapa, Veracruz, México. 72 pp.

Avendaño-Sánchez, H. \& O. Sotomayor-Navarro. 1982. Estructura y distribución de las comunidades fitoplanctónicas de la zona sureste del Golfo de México, verano de 1980. Vol. 1. Investigaciones Oceanográficas. Secretaría de Marina, Dirección General de Oceanografía, Biología Marina, México, D.F., México. pp. 79-96.

Balech, E. 1951. Sobre dos variedades de Dinophysis caudata Kent. Com. Zool. Mus. Hist. Natur. Montevideo 3(60): 1-9, pl. 1-4.

Balech, E. 1956. Étude des dinoflagellés du sable de Roscoff. Rev. Algol. 2: 29-52.

Balech, E. 1962. Plancton de las campañas oceanográficas Drake I y II. Servicio de Hidrografía Naval (Armada Argentina) Publ. H. 627. Buenos Aires, Argentina. 57 pp.

Balech, E. 1967a. Dinoflagelados nuevos o interesantes del Golfo de México y Caribe. Rev. Mus. Argent. Cienc. Natur. “B. Rivadavia” Inst. Nac. Invest. Cienc. Natur., Hidrobiol. 2(3): 77-126, pl. 1-9.

Balech, E. 1967b. Microplancton of the Gulf of Mexico and the Caribbean Sea. A\&M Project 382, National Institutes of Health Grants No. ES 00042-01 \& 02. Department of Oceanography, Texas A\&M University. College Station, USA. 144 pp.

Balech, E. 1971a. Microplancton de la campaña oceanográfica Productividad III. Rev. Mus. Argent. Cienc. Natur. “B. Rivadavia” Inst. Nac. Invest. Cienc. Natur., Hidrobiol. 3(1): 1-202, pl. 1-39.

Balech, E. 1971b. Microplancton del Atlántico ecuatorial oeste (Equalant I). Servicio de Hidrografía Naval (Armada Argentina) Publ. H. 654. Buenos Aires, Argentina. 103 pp., pl. 1-12.

Balech, E. 1977. Estructura de Amphisolenia bidentata Schröder (Dinoflagellata). Physis (Buenos Aires), Secc. A 37(93): 25-32.

Balech, E. 1988. Los dinoflagelados del Atlantico Sudoccidental. Ministerio de Agricultura Pesca y Alimentación - Instituto Español de Oceanografía. Madrid, España. 310 pp.

Bérard-Therriault, L., M. Polulin \& L. Bosse. 1999. Guide d'identification du phytoplancton marin de l'estuaire et du golfe du Saint-Laurent incluant également certains protozoaires. Les Presses Scientifiques de CNRC. Ottawa, Canada. 387 pp. 
Böhm, A. 1933. Zur Kenntnis der antarktischen Dinophysiaceae. Int. Rev. Hydrobiol. 29: 15-16.

Böhm, A. 1935. Zur Variationsproblem der Peridineen. Öst. Bot. Z. 84: 271-281.

Böhm, A. 1936. Dinoflagellates of the coastal waters of the western Pacific. Bull. Bernice P. Bishop Mus. Bull. 137: 1-54.

Bravo, I., R. I. Figueroa, E. Garcés, S. Fraga \& A. Massanet. 2009. The intricacies of dinoflagellate pellicle cysts: The example of Alexandrium minutum cysts from a bloom-recurrent area (Bay of Baiona, NW Spain). Deep-Sea Res. II 57: 166-174.

Brummitt, R. K. \& C. E. Powell (eds.). 1992. Authors of plant names. A list of authors of scientific names of plants with recommended standard forms of their names, including abbreviations. Royal Botanic Gardens, Kew. Kew, UK. 732 pp.

Campbell, L., R. J. Olson, H. M. Sosik, A. Abraham, D. W. Henricks, C. J. Hyatt \& E. J. Buskey. 2010. First harmful Dinophysis (Dinophyceae, Dinophysiales) bloom in the U.S. is revealed by automated imaging flow cytometry. J. Phycol. 46: 66-75.

Cannon, J. A. 1993. Germination of the toxic dinoflagellate, Alexandrium minutum, from sediments in the Port River, South Australia. In: Smayda, T. J. \& Y. Shimizu (eds.). Toxic phytoplankton blooms in the sea. Elsevier. Amsterdam, The Netherlands. pp. 103-107.

Carpenter, E. J. 2002. Marine cyanobacterial symbioses. Biol. Environ. 102B: 15-18.

Curl, H., Jr. 1959. The phytoplankton of Apalachee Bay and the Northeastern Gulf of Mexico. Publications of the Institute of Marine Science. The University of Texas. Port Aransas, USA. 6: 277-320.

Delgado, M. \& J.-M. Fortuño. 1991. Atlas de fitoplancton del Mar Mediterraneo. Sci. Mar. 55 (Supl. 1): 1-133.

Dodge, J. D. 1982. Marine dinoflagellates of the British Isles. Her Majesty's Stationary Office. London, UK. vi +303 pp.

Dodge, J. D. 1985. Atlas of dinoflagellates. Farrand Press. London, UK. 119 pp.

Drebes, G. 1974. Marines Phytoplankton. Eine Auswahl der Helgolander Planktonalgen (Diatomeen, Peridineen). G. Thieme Verlag. Stuttgart, Germany. 186 pp.

Elbrächter, M. 1991. Food uptake mechanisms in phagotrophic dinoflagellates and classification. In: Patterson, D. J. \& J. Larsen (eds.). The biology of free-living heterotrophic flagellates. Systematics Association Special Volume 45. Clarendon Press. Oxford, UK. pp. 303-312.

Escalera, L., B. Reguera, K. Takishita, S. Yoshimatsu, K. Koike \& K. Koike. 2011. Cyanobacterial endosymbionts in the benthic dinoflagellate Sinophysis canaliculata (Dinophysiales, Dinophyceae). Protist 162: 304-314.

Esqueda-Lara, K. \& D. U. Hernández-Becerril. 2010. Dinoflagelados microplanctónicos marinos del Pacífico central de México (Isla Isabel, Nayarit y costas de Jalisco y Colima). Instituto de Ciencias del Mar y Limnología, Universidad Nacional Autónoma de México. México, D.F., México. x + 206 pp.

Estradas-Romero, A. 2004. Abundancia y distribución del fitoplancton en dos transectos, uno frente al Río Coatzacoalcos y otro frente al sistema Grijalva-Usumasinta (Marzo 2000). Tesis de Maestría. Posgrado en Ciencias del Mar y Limnología, Universidad Nacional Autónoma de México. México, D.F., México. 70 pp. 
Faust, M. A. 1993. Surface morphology of the marine dinoflagellate Sinophysis microcephalus (Dinophyceae) from a mangrove island, Twin Cays, Belize. J. Phycol. 29: 355-363.

Faust, M. A. \& R. A. Gulledge. 2002. Identifying harmful marine dinoflagellates. Contr. U.S. Natl. Herbarium 42: 1-144.

Fensome, R. A., F. J. R. Taylor, G. Norris, W. A. S. Sarjeant, D. I. Wharton \& G. L. Williams. 1993. A classification of living and fossil dinoflagellates. Sheridan Press. Hanover, USA. $351 \mathrm{pp}$.

Figueroa-Torres, M. G. \& I. Weiss-Martínez. 1999. Dinoflagelados (Dinophyceae) de la laguna de Tamiahua, Veracruz, México. Rev. Biol. Trop. 47(Supl. 1): 43-46.

Forti, A. 1932. Una rara Dinofisea del Mediterraneo per la prima volta descritta. Arch. Protistenk. 77: 538-542.

Fukuyo, Y., H. Takano, M. Chihara \& K. Matsuoka (eds.). 1990. Red tide organisms in Japan. An illustrated taxonomic guide. Uchida Rokakuho, Co., Ltd. Tokyo, Japan. 407 pp.

Fux, E., J. L. Smith, M. Tong, L. Guzmán \& D. M. Anderson. 2011. Toxin profiles of five geographical isolates of Dinophysis spp. from North and South America. Toxicon 57: 275-287.

García-Reséndiz, J. A. 2003. Estructura del fitoplancton y su relación con las condiciones oceanográficas en el sureste del Golfo de México (abril 2000). Tesis Profesional. Facultad de Biología, Universidad Veracruzana. Xalapa, México. 46 pp.

Gómez, F., P. López-García \& D. Moreira. 2011a. Molecular phylogeny of dinophysoid dinoflagellates: the systematic position of Oxyphysis oxytoxoides and the Dinophysis hastata group (Dinophysales, Dinophyceae). J. Phycol. 47: 393-406.

Gómez, F., D. Moreira \& P. López-García. 2011b. Avances en el estudio de los dinoflagelados (Dinophyceae) con la filogenia molecular. Hidrobiológica 21(3): 343-364.

Gómez, F., D. Moreira \& P. López-García. 2012. Sinophysis and Pseudophalacroma are distantly related to typical dinophysoid dinoflagellates (Dinophysales, Dinophyceae). J. Euk. Microbiol.: 59(2): 188-190 doi: 10.1111/j.1550-7408.2011.00598.x

Gordon, N., D. L. Angel, A. Neori, N. Kress \& B. Kimor. 1994. Heterotrophic dinoflagellates with symbiotic cyanobacteria and nitrogen limitation in the Gulf of Agaba. Mar. Ecol. Prog. Ser. 107: 83-88.

Halim, Y. 1967. Dinoflagellates of the South-East Caribbean Sea (East-Venezuela). Int. Revue Ges. Hydrobiol. 52(5): 701-755.

Hallegraeff, G. M. \& S. W. Jeffrey. 1984. Tropical phytoplankton species and pigments of continental shelf waters of North and North-West Australia. Mar. Ecol. Prog. Ser. 20: 59-74.

Hallegraeff, G. \& I. A. N. Lucas. 1988. The marine dinoflagellate genus Dinophysis (Dinophyceae): photosynthetic, neritic and non-photosynthetic, oceanic species. Phycologia 27(1): 25-42.

Handy, S. M., T. R. Bachvaroff, R. E. Timme, D. W. Coats, S. Kim \& C. F. Delwiche. 2009. Phylogeny of four dinophysiacean genera (Dinophyceae, Dinophysiales) based on rDNA sequences from single cells and environmental samples. J. Phycol. 45: 1163-1174.

Hansen, G. 1993. Dimorphic individuals of Dinophysis acuta and D. norvegica (Dinophyceae) from Danish waters. Phycologia 32(1): 73-75. 
Hansen, G., J. Turquet, J. P. Quod, L.Ten-Hage, C. Lugomela, M. Kyewalyanga, M. Hurbungs, P. Wawiye, B. Ogongo, S. Tunje \& H. Rakotoarinjanahary. 2001. Potentially harmful microalgae of the Western Indian Ocean - a guide based on a preliminary survey. Intergovernmental Oceanographic Commission, Manuals and Guides 41. UNESCO. Paris, France. 105 pp.

Head, M. J. 1996. Modern dinoflagellate cysts and their biological affinities. In: Jansonius, J. \& D. C. McGregor (eds.). Palynology: principles and applications. Vol. 3 American Association of Stratigraphic Palynologists Foundation. Dallas, USA. pp. 1197-1248.

Herdman, E. C. 1924. Notes on dinoflagellates and other organisms causing discolouration of the sand at Port Erin. IV. Proc. Trans. Liverpool Biol. Soc. 38: 75-84.

Hermosilla, J. G. 1973. Contribución al conocimiento sistemático de los dinoflagelados de la Bahía de Concepción, Chile. Gayana, Zool. 24: 1-149.

Hernández-Becerril, D. U. 1988a. Especies de fitoplancton tropical del Pacífico mexicano. II. Dinoflagelados y cianobacterias. Rev. Lat.-Amer. Microbiol. 30: 187-196.

Hernández-Becerril, D. U. 1988b. Planktonic dinoflagellates (except Ceratium and Protoperidinium) from the Gulf of California and off the coasts of Baja California. Bot. Mar. 31: 423-435.

Hernández-Becerril, D. U., J. A. García-Reséndiz, D. A. Salas de León, M. A. MonrealGómez, M. Signoret-Poillon \& J. Aldeco-Ramírez. 2008. Fracción de nanoplancton en la estructura del fitoplancton en el sur del Golfo de México (abril de 2000). Cienc. Mar. 34(1): 77-90.

Hernández-Mendiola, M. 1988. Fluctuaciones espacio-temporales en la estructura de la comunidad fitoplanctónica, en la zona estuarina del río La Antigua, Veracruz, México. Tesis Profesional. Facultad de Biología, Universidad Veracruzana. Xalapa, México. 88 pp.

Hernández-Rosas, A., M. E. Meave del Castillo, M. E. Zamudio-Resendiz \& M. CastilloRivera. 2007. Morfometría y distribución de especies del género Ornithocercus (Dinophysiales: Dinophyta) del Pacífico Mexicano. Hidrobiológica 17(3): 257-272.

Hess, P. \& E. Nicolau. 2010. Recent developments in the detection of phycotoxins. In: Barbier, J., E. Benoit, P. Marchot, C. Mattei \& D. Servent (eds.). Advances and new technologies in toxinology, 18th Meeting on Toxinology, December 13 and 14, 2010. Société Française pour l'Etude des Toxines Ed. Paris, France. pp. 35-41.

Hoppenrath, M. 2000. Morphology and taxonomy of Sinophysis (Dinophyceae, Dinophysiales) including two new marine sand-dwelling species from the North German Wadden Sea. Eur. J. Phycol. 35: 153-162.

Hoppenrath, M., M. Elbrächter \& G. Drebes. 2009. Marine phytoplankton. Selected microphytoplankton species from the North Sea around Helgoland and Sylt. E. Schweizerbart'sche Verlagsbuchhandlung (Nägele u. Obermüller), Stuttgart, Germany. 264 pp.

Jensen, H. M. \& N. Daugbjerg. 2009. Molecular phylogeny of the order Dinophysiales (Dinophyceae) - testing the hypothesis of a dinophysioid radiation. J. Phycol. 45(5): 1136-1152.

Kofoid, C. A. 1907. New species of dinoflagellates. IX. Reports of the Scientific Results of the Expedition to the Eastern Tropical Pacific, in charge of Alexander Agassiz, by 
the U.S. Fish Commission Steamer "Albatross", from October, 1904, to March, 1905, Lieut. Commander L. M. Garrett, U.S.N., commanding. Bull. Mus. Compar. Zool. Harvard Coll. 50(6): 163-207, 17 pl.

Kofoid, C. A. \& T. Skogsberg. 1928. The Dinoflagellata: the Dinophysoidae. Mem. Mus. Compar. Zool. Harvard Coll. 51: 1-706, pl. 1-31.

Larsen, J. \& Ø. Moestrup. 1989. Guide to toxic and potentially toxic marine algae. The Fish Inspection Service, Ministry of Fisheries. Copenhagen, Denmark. 61 pp.

Larsen, J. \& Ø. Moestrup. 1992. Leaflet No. 180. Potentially toxic phytoplankton. 2. Genus Dinophysis (Dinophyceae). In: Lindley, J. A. (ed.). ICES Identification Leaflets for Plankton. International Council for the Exploration of the Sea. Copenhagen, Denmark. 12 pp.

Larsen, J. \& N. L. Nguyen. 2004. Dinophysiales. In: Larsen, J. \& N. L. Nguyen. (eds.). Potentially toxic microalgae of Vietnamese waters. Opera Bot. 140: 63-73.

Lebour, M. V. 1925. The dinoflagellates of northern seas. The Marine Biological Association of the United Kingdom, Plymouth, UK. 250 pp.

Legaría-Moreno, L. 2003. Dinámica del fitoplancton y su relación con variables físicoquímicos en la laguna costera La Mancha, Ver., Méx. Tesis Profesional. Facultad de Biología, Universidad Veracruzana. Xalapa, Veracruz, México. 138 pp.

Lemmermann, E. 1899. Planktonalgen. Ergebnisse einer Reise nach dem Pazifik (H. Schauisland 1896/97). Abhandl. Naturwiss. Ver. Bremen 16(2): 313-398, pl. 1-3.

Licea, S., J. L. Moreno, H. Santoyo \& G. Figueroa. 1995. Dinoflageladas del Golfo de California. Universidad Autónoma de Baja California Sur, Secretaría de Educación Pública - Fondo para la Modernización de la Educación Superior, Programa Interdisciplinario e Interinstitucional Mar de Cortés. La Paz, México. xii + 165 pp.

Licea, S., M. E. Zamudio, R. Luna \& J. Soto. 2004. Free-living dinoflagellates in the southern Gulf of Mexico: report of data (1979-2002). Phycol. Res. 52: 419-428.

Lucas, I. A. N. 1991. Symbionts of the tropical Dinophysiales (Dinophyceae). Ophelia 33: 213-224.

Lucas, I. \& M. Vesk. 1990. The fine-structure of two photosynthetic species of Dinophysis (Dinophysiales, Dinophyceae). J. Phycol. 26: 345-357.

Martin, G. W. 1929. Dinoflagellates from marine and brackish waters of New Jersey. Univ. Iowa Stud. Nat. Hist. 12(9): 1-32, pl. 1-8.

Matzenauer, L. 1933. Die Dinoflagellaten des Indischen Ozeans. Bot. Arch. 35: 437-510.

Meunier, A. 1910. Microplankton des mers de Barents et de Kara. Duc d'Orleans Campagne Arctique de 1907. Ch. Bulens, Bruxelles. xviii +355 pp., 37 pl.

Mohammad-Noor, N., N. Daugbjerg, Ø. Moestrup \& A. Anton. 2007. Marine epiphytic dinoflagellates from Malaysia - a study of live cultures and preserved samples based on light and scanning electron microscopy. Nordic J. Bot. 24: 629-690.

Moita, M. T. \& M. A. de M. Sampayo. 1993. Are there cysts in the genus Dinophysis? In: Smayda, T. J. \& Y. Shimizu (eds.) Toxic phytoplankton blooms in the sea. Elsevier, Amsterdam. pp. 153-158.

Murray, G. \& F. G. Whitting. 1899. New Peridiniaceae from the Atlantic. Trans. Linn. Soc. London, Bot. 5(9): 321-342, pl. 27-33, tables 1-9.

Nie, D. \& C.-C. Wang. 1944. Dinoflagellata of the Hainan region, VIII. On Sinophysis microcephalus, a new genus and species of Dinophysidae. Sinensia 15: 145-151. 
Nishitani, G., S. Nagai, S. Sakiyama \& T. Kamiyama. 2008. Successful cultivation of the toxic dinoflagellate Dinophysis caudata (Dinophyceae). Plankton Benthos Res. 3(2): 78-85.

Norris, D. R. 1967. Algal consortisms in marine plankton. In: Krishnamurthy, V. (ed.). Proceedings of a Seminar on Sea, Salts and Plants, 1965. Central Salt and Marine Chemical Research Institute. Bhavnagar, India. pp. 178-189.

Norris, D. R. 1969. Thecal morphology of Ornithocercus magnificus (Dinoflagellata) with notes on related species. Bull. Mar. Sci. 19(1): 175-197.

Norris, D. R. \& L. D. Berner, Jr. 1970. Thecal morphology of selected species of Dinophysis (Dinoflagellata) from the Gulf of Mexico. Contr. Mar. Sci. Univ. Texas 15: 145-192.

Okolodkov, Y. B., G. Campos-Bautista, I. Gárate-Lizárraga, J. A. G. González-González, M. Hoppenrath \& V. Arenas. 2007. Seasonal changes of benthic and epiphytic dinoflagellates in the Veracruz reef zone, Gulf of Mexico. Aquat. Microb. Ecol. 47(3): 223-237.

Okolodkov, Y. B., J. A. Aké-Castillo, M. G. Gutiérrez-Quevedo, H. Pérez-España \& D. Salas-Monreal. 2011. Annual cycle of the plankton biomass in the National Park Sistema Arrecifal Veracruzano, southwestern Gulf of Mexico. In: Kattel, G. (ed.). Zooplankton and phytoplankton: Types, characteristics and ecology. Nova Science Publishers, Inc. New York, USA. pp. 63-88.

Park, M. G., S. Kim, H. S. Kim, G. Myung, Y. G. Kang \& W Yih. 2006. First successful culture of the marine dinoflagellate Dinophysis acuminata. Aquat. Microb. Ecol. 45: 101-106.

Parra-Toriz, D., M. de L. A. Ramírez-Rodríguez \& D. U. Hernández-Becerril. 2011. Dinoflagelados planctónicos del orden Dinophysiales (Dinophyta) del suroeste del Golfo de México. Bol. Soc. Argent. Bot. 46, supl. 2: 203-204.

Paulsen, O. 1908. Peridiniales. Nordisches Plankton. Botanischer Teil. Verlag von Lipsius \& Tischer. Kiel, Leipzig, Germany. 124 pp.

Paulsen, O. 1931. Études sur le microplancton de la mer d'Alboran. Trab. Inst. Esp. Oceanogr. 4: 1-108.

Pavillard, J. 1909. Sur les péridiniens du Golfe du Lion. Bull. Soc. Bot. Fr., Sér. 4, 9: 277284.

Pavillard, J. 1916. Recherches sur les péridiniens du Golfe du Lion. Trav. Inst. Bot., Univ. Montpellier, Sér. Mixte, Mem. 4: 9-70, pl. 1-3.

Pesantes-Santana, F. 1978. Dinoflagelados del fitoplancton del Golfo de Guayaquil. Publ. Instituto Oceanográfico, Armada del Ecuador, Guayaquil, Ecuador 2(2): 1-98.

Quod, J.-P., L. Ten-Hage, J. Turquet, G. Mascarell \& A. Couté. 1999. Sinophysis canaliculata sp. nov. (Dinophyceae), a new benthic dinoflagellate from western Indian Ocean. Phycologia 38: 87-91.

Rampi, L. 1939. Su qualche Peridinea rara, nuova o curiosa nel fitoplancton del mare Ligure. Nuovo Giorn. Bot. Ital. n s. 46(3): 456-469.

Rampi, L. 1940. Richerche sul fitoplancton del mare Ligure. Boll. Pesca Piscic. Idrobiol. 2: 1-34.

Rampi, L. 1941. I generi Histioneis Stein e Parahistioneis Kof. a. Skogsb. nel bacino Mediterraneo. Riv. Sci. Natur. 32: 118-122. 
Rampi, L. 1947. Osservazioni sulle Histioneis (Peridinee) raccolte nel mare Ligure presso Sanremo. Bull. l'Inst. Océanogr. Monaco 920: 1-14.

Reguera, B. 2002. Small cells in Dinophysis spp: a life cycle strategy for phytoplankters with a holoplanktonic way of living? In: Garcés, E., A. Zingone, M. Montresor, B. Reguera \& B. Dale (eds.). Report of the Workshop on: LIFEHAB: Life histories of microalgal species causing harmful blooms. Research in Enclosed Seas Series 12. European Commission Brussels. Brussels, Belgium. pp. 60-63.

Reguera, B., I. Bravo \& S. Fraga. 1995. Autecology and some life history stages of Dinophysis acuta Ehrenberg. J. Plankton Res. 17(5): 999-1015.

Reguera, B. \& S. González-Gil. 2001. Small cell and intermediate cell formation in species of Dinophysis (Dinophyceae, Dinophysiales). J. Phycol. 37: 318-333.

Reguera, B., S. González-Gil \& M. Delgado. 2007. Dinophysis diegensis is a life history stage of Dinophysis caudata (Dinophyceae, Dinophysiales). J. Phycol. 43: 1083-1093.

Reguera, B., L. Velo-Suárez, R. Raine \& M. G. Park. 2012. Harmful Dinophysis species: A review. Harmful Algae 14: 87-106.

Salas-Pérez, J. de J., D. Salas-Moreal, M. A. Monreal-Gómez, M. L. Riveron-Enzastinga \& C. Llasat. 2012. Seasonal absolute acoustic intensity, atmospheric forcing and currents in a tropical coral reef system. Estuar. Coast. Shelf Sci. 100: 102-112.

Saldarriaga, J. F., F. J. R. Taylor, T. Cavalier-Smith, S. Menden-Deuer \& P. J. Keeling. 2004. Molecular data and the evolutionary history of dinoflagellates. Europ. J. Protistol. 40: 85-111.

Saunders, R. D. \& J. D. Dodge. 1984. A SEM study and taxonomic revision of some armoured sand-dwelling marine dinoflagellates. Protistologica 20: 271-283.

Schiller, J. 1928. Die planktischen Vegetationen des adriatischen Meeres. C. Dinoflagellata. 1 Teil. Adiniferida, Dinophysidaceae. Systematischer Teil. Arch. Protistenk. 61(1): 45-91, pl. 3.

Schiller, J. 1933. Dinoflagellatae (Peridineae). Teil 1. Akademische Verlagsgesellschaft M.B.H. Leipzig, Germany. 617 pp.

Schröder, B. 1900. Phytoplankton des Golfes von Neapel. Mitt. Zool. Stat. Neapel 14: 1-38, 1 pl.

Schütt, F. 1895. Die Peridineen der Plankton Expedition. Ergebnisse der Plankton-Expedition der Humboldt Stiftung 4: 1-170, pl. 1-27.

Schütt, F. 1896. Peridiniales. In: Engler, A. \& K. Prantl(eds.). Die natürlichen Pflanzenfamilien 1B: $1-30$.

Schütt, F. 1899. Centrifugales Dickenwachstum der Membran und extramembranöses Plasma. Jahrb. Wiss. Bot. 33: 594-690, pl. 6-8.

Schütt, F. 1900. Die Erklärung des centrifugalen Dickenwachsthums der Membran. Bot. Zeit. 58: 245-273, 1 pl.

Selina, M. \& M. Hoppenrath. 2004. Morphology of Sinophysis minima sp. nov. and three Sinophysis species (Dinophyceae, Dinophysiales) from the Sea of Japan. Phycol. Res. 52: 149-159.

Silva, E. S. 1955. Dinoflagelados do plankton marinho de Angola. An. Junta Invest. Ultramar 10(2): 109-191.

Silva, E. S. 1956. Contribution à l'étude du microplancton de Dakar et des régions maritimes voisines. Bull. Franç. Afr. Noire, sér. A, 18(2): 335-371. 
Steidinger, K. A., J. T. Davis \& J. Williams. 1967. A key to the marine dinoflagellate genera of the west coast of Florida. Florida Board of Conservation Marine Laboratory. St. Petersburg, USA. vi +45 pp., pl. I-IX.

Steidinger, K. A., A. M. Faust \& D. U. Hernández-Becerril. 2009. Dinoflagellates (Dinoflagellata) of the Gulf of Mexico. In: Tunnel, J. W. Jr., D. L. Felder \& S. A. Earl (eds.). Gulf of Mexico origin, waters, and biota. Vol. 1. Biodiversity. Harte Research Institute for Gulf of Mexico Studies Series. Texas A\&M University Press. Corpus Christi, USA. pp. 131-154.

Steidinger, K. A. \& K. Tangen. 1996. Dinoflagellates. Chapter 3. In: Tomas, C. R. (ed.). Identifying marine diatoms and dinoflagellates. Academic Press, Inc. San Diego, USA. pp. 387-584.

Steidinger, K. A. \& J. Williams. 1970. Dinoflagellates. Memoirs of the Hourglass Cruises 2. Marine Research Laboratory, Florida Department of Natural Resources. St. Petersburg, USA. 251 pp., pl. 1-45.

Stein, F. R. 1883. Der Organismus der Infusionsthiere nach eigenen Forschungen in systematischer Reihenfolge bearbeitet. III Abteilung. II. Hälfte. Die Naturgeschichte der arthrodelen Flagellaten. Leipzig, Germany. 30 pp., 25 pl.

Suchil-Vilchis, M. A. 1990. Determinación de la variación estacional del fitoplancton, y su relación con los parámetros físicos y químicos de las lagunas de: Sontecomapan y del Ostión/ Ver. para el año de 1985. Tesis Profesional. Escuela Nacional de Estudios Profesionales-Zaragoza, Universidad Nacional Autónoma de México. México, D.F., México. 117 pp.

Swanson, K. M., L. J. Flewelling, M. Byrd, A. Nunez \& T. A. Villareal. 2010. The 2008 Texas Dinophysis ovum bloom: Distribution and toxicity. Harmful Algae 9: 190-199.

Tai, L.-S. \& T. Skogsberg. 1934. Studies on the Dinophysoidae, marine armored dinoflagellates, of Monterey Bay, California. Arch. Protistenk. 82(3): 380-482, pl. 11-12.

Taylor, F. J. R. 1976. Dinoflagellates from the International Indian Ocean Expedition. A report on material collected by the R. V. «Anton Bruun» 1963-1964. Bibliotheca Bot. 132: 1- 234 pp. 1-46.

Taylor, F. J. R. 1978. Dinoflagellates (Chapter 6. Identification problems. Some specific preparations). In: Sournia, A. (ed.). Phytoplankton manual. Monographs on Oceanographic Methodology 6. UNESCO. Paris, France. pp. 143-147.

Taylor, F. J. R. 1982. Symbiosis in marine microplankton. Ann. Inst. Oceanogr. Paris (Nouv. Ser.) 58(Suppl.): 61-90.

Tejeda-Hernández, I. E. 2005. Identificación y cuantificación de microalgas productoras de marea roja, en las costas de Veracruz, Boca del Río y Antón Lizardo durante la primavera y verano del 2003. Tesis Profesional. Instituto Tecnológico del Mar. Boca del Río, Veracruz, México. 84 pp.

Tester, L. A. \& K. A. Steidinger. 1979. Phytoplankton, 1971-1973. Florida Mar. Res. Publ. 34: 16-61.

Tong, M., Q. Zhou, M. D. Kulis, T. Jiang, Y. Qi \& M. D. Anderson. 2010. Culture techniques and growth characteristics of Dinophysis acuminata and its prey. Chin. J. Oceanol. Limnol. 28(6): 1230-1239. 
Wood, E. J. F. 1963. Dinoflagellates in the Australian Region. III. Further collections. Div. Fisher. Oceanogr. Tech. Paper 17, Commonwealth Scientific and Industrial Research Organization. Melbourne, Australia. $20 \mathrm{pp}$.

Wood, E. J. F. 1968. Dinoflagellates of the Caribbean Sea and adjacent areas. University of Miami Press. Coral Gables, USA. 142 pp.

Yamaji, I. 1966. Illustrations of the marine plankton of Japan. Hoikusha Publishing Co., Ltd. Osaka, Japan. 372 pp.

Zamudio-Resendiz, M. E. 1998. Hidrología y fitoplancton en una región costera al oeste del Golfo de México. Tesis de Maestría. Instituto de Ciencias del Mar y Limnología, Colegio de Ciencias y Humanidades, Universidad Nacional Autónoma de México. México, D.F., México. 66 pp. 